\title{
Using Digital Technologies for Early Education during COVID-19
}

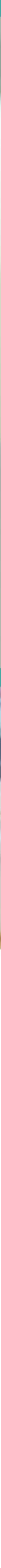




\section{Acknowledgements}

Sincere thanks are due, particularly in the context of the COVID- 19 pandemic, to the many people who contributed to and helped shape the present brochure, Using Digital Technologies for Early Education during COVID- 19.

This brochure was produced by the Organisation for Economic Co-operation and Development (OECD) at the request of G2O under the Saudi Arabian presidency in 2020. The financial support of the Kingdom of Saudi Arabia is gratefully acknowledged. The data underlying this report, which reflects the situation in 2020, was gathered through a policy survey administered in G20, OECD and partner countries. Designed for government officials responsible for early levels of education, the survey collected information about national or regional strategies on the use of digital technologies for maintaining continuity of education for young children in 2020. Special thanks go to respondents to the survey.

Our special thanks also go to members of the G20 Education Working Group and to members of the OECD Network on Early Childhood Education and Care (ECEC), who provided guidance on the design of the questionnaire, co-ordinated the national responses to the survey, and provided guidance and comments throughout the process.

The brochure was prepared under the responsibility of Andreas Schleicher, Special Advisor on Education Policy to the OECD Secretary-General and Director for Education and Skills, and Yuri Belfali, Head of the Early Childhood and Schools Division. The project was managed by Stéphanie Jamet, and the brochure prepared and drafted by Carlos González-Sancho and Judit Pál, with contributions from Andrea Konstantinidi. The work benefited also from the input and expertise of Malek Abu-Jawdeh, Étienne Albiser, Eric Charbonnier, Elizabeth Fordham, Corrine Heckmann, Kateryna Obvintseva and Elizabeth Shuey. Cassandra Davis, Taline Shahinian and Della Shin provided valuable support in the editorial and production process. 


\section{G20}

The Group of Twenty (G20) is a leading forum of major economies that seeks to develop global policies to address the world's most pressing challenges. Collectively, G20 members account for two-thirds of the world's population, 80 percent of its economic output, and 75 percent of its trade. The G20 members are: Argentina, Australia, Brazil, Canada, China, France, Germany, Japan, India, Indonesia, Italy, Mexico, Russia, South Africa, Saudi Arabia, South Korea, Turkey, the United Kingdom, the United States, and the European Union. Each year the Presidency invites guest countries, to ensure a broader representation of the group, which take full part in the $\mathrm{G} 20$ discussions. In addition to $\mathrm{G} 20$ countries, Spain is invited as a permanent guest and Singapore has been invited to participate in the G20 Summits and related processes from 2010 to 2011 and from 2013 to 2020. Severalinternational and regional organisations also participate to support the policy discussions and help countries in delivering on their commitments. 


\section{Foreword}

Coronavirus infections have luckily proven less harmful for young children than for adults. Yet, the youngest members of society have not been spared many of the consequences of the COVID- 19 crisis, including severe disruptions to the functioning of early education, especially during the first wave of the pandemic in 2020. While most OECD and G2O countries closed their early childhood education and care services and primary schools for shorter periods than secondary schools or universities, continuing to provide support and learning opportunities for young children proved particularly difficult given the importance of in-person interactions in the early years and the limited availability of digital alternatives adapted to these age groups.

The unprecedented challenges that the COVID-19 pandemic brought to education made it difficult to apply lessons from the past, but improving preparedness for the years to come makes it imperative to take stock of how education systems responded to the crisis and to derive insights for better adapting education to the "new normal". To support this, the OECD has collected comparative education statistics through a series of special surveys and issued a series of reports and policy briefs looking at aspects ranging from lost learning opportunities and contingency strategies to make up for these, to the organisation of learning and the working conditions of teachers, and to issues around governance and finance.

This latest report investigates how digital technologies were used to maintain continuity of education for young children in 2020, which challenges arose and what policy changes are in the pipeline for early education, drawing on a policy survey completed by 34 countries and jurisdictions. It shows that policy responses varied notably across OECD and G20 countries, from the length of closures to the degree of reliance on screens and interactive platforms to provide educational activities. At the same time, the results reveal many widely shared strategies, including an extensive use of digital tools to maintain communication with families and targeted measures to better support young children from less advantaged backgrounds. Importantly, the report also shows that the pandemic accelerated the adoption of measures to protect young children in digital environments and suggests that it will motivate a revision of policies regarding the use of digital technologies in early education. For example, strengthening the preparation of early education professionals for promoting effective and safe uses of technology with young children is being reported as an emerging priority by many countries.

We know all too well how deeply the COVID-19 pandemic disrupted education systems at all levels. The reports in this series shed light on the possibilities for education policies to mitigate the implications of these disruptions. It is the nature of our collective responses to these challenges that will determine how we are ultimately affected by them.

Andreas Schleicher,

Director for Education and Skills

Special Advisor on Education Policy to the OECD Secretary-General 


\section{Table of contents}

Acknowledgements

Foreword 3

Executive summary 6

Background and rationale $\quad 8$

1 Duration and scope of closures of early education centres and schools in $2020 \quad 11$

2 Approaches to the use of digital technology in early education prior to the pandemic

3 Maintaining continuity of education for young children in 202022

Responsibilities and work requirements during school/centre closures 23

Using digital technology to maintain continuity of education 24

Prior approaches and use of real-time and interactive solutions in $2020 \quad 30$

$\begin{array}{ll}\text { Prioritisation of curriculum areas in distance education } & 31\end{array}$

Using digital technologies to engage with parents and families 33

Use of broadcast technologies $\quad 35$

4 Challenges and adaptations 38

Challenges $\quad 38$

A learning curve? $\quad 42$

Protecting children against digital risks $\quad 43$

Perceived effectiveness $\quad 45$

5 Supporting vulnerable groups of young children during distance education $\quad 47$

6 Strategies going forward 52

References $\quad 56$

Annex A. List of tables $\quad 58$ 


\section{FIGURES}

Figure 1.1. Closure of early education schools/centres in 2020

Figure 1.2. Scope of early education school/centre closures in 2020

Figure 1.3. Closures of schools/centres by 15 April and 15 November $2020 \quad 15$

Figure 1.4. Length of full closures of early education schools/centres in 2020 due to the COVID-19 pandemic 16

Figure 2.1. Uses of digital technologies in early education prior to the COVID-19 pandemic 18

Figure 2.2. Country profiles in the use of digital technologies in early education prior to the COVID-19 pandemic 19

Figure 2.3. Locus of responsibility regarding the use of digital technology in early education 20

Figure 3.1. Locus of responsibility for organising alternative education arrangements during school/centre closures in $2020 \quad 23$

Figure 3.2. Work requirements for teachers during school/centre closures in $2020 \quad 24$

Figure 3.3. Use of digital technologies in response to the COVID-19 pandemic 26

Figure 3.4. Importance of different types of digital technologies in maintaining continuity of education for young children in $2020 \quad 27$

Figure 3.5. Type of digital technologies used to maintain continuity of education for young children 28

Figure 3.6. Time spent using digital tools as part of distance education activities in $2020 \quad 29$

Figure 3.7. Country profiles for the association between prior expectations for the use of technology in early education and importance of interactive solutions in $2020 \quad 30$

Figure 3.8. Prioritisation of pre-primary curriculum areas during distance education in $2020 \quad 32$

Figure 3.9. Prioritisation of primary curriculum areas during distance education in 2020

Figure 3.10. Extent of use of digital technologies for purposes other than direct education delivery 34

Figure 3.1 1. Country profiles in the use of digital technologies in 2020 for purposes other than direct education delivery 35

Figure 3.12. Importance of broadcast technologies for maintaining continuity of education for young children in $2020 \quad 37$

Figure 4. 1. Main challenges encountered in using digital technologies to maintain continuity of education for young children in 2020

Figure 4.2. Measures to support teachers in using digital technologies for distance education during school/centre closures in $2020 \quad 40$

Figure 4.3. Measures to support parents/families for maintaining continuity of education in 2020

Figure 4.4. Use of digital technologies for real-time activities across periods of closure in 2020

Figure 4.5. Measures to protect young children against risks of digital technologies 44

Figure 4.6. Perceived effectiveness of distance education in 2020

Figure 5.1. Groups of young children at risk of exclusion from distance education in 2020

Figure 5.2. Measures implemented to support children in vulnerable groups in accessing distance education in $2020 \quad 50$

Figure 6.1. Strategies to integrate digital technologies in early education by 2025

Figure 6.2. Measures to support professional learning for the use of digital technologies and distance education by 2025

\section{TABLES}

Table A. 1. Prioritisation of development areas/skills when digital technologies used to maintain continuity of education for young children

Table A.2. Continuity of work requirements for centre/school leaders during school/centre closures

Table A.3. Use of broadcast technologies to maintain continuity of education for young children 61

Table A.4. Reasons for difficulties to maintain continuity of education for groups of young children 63

Table A.5. Change in approach to integrating digital technologies in early education 67 


\section{Executive summary}

Digitalisation has unevenly permeated early levels of education across $G 20$ and $O E C D$ countries, reflecting open debates about the extent to which digital technologies should be part of young children's learning experiences. However, the disruptions brought about by the COVID- 19 pandemic compelled countries to rely on digital solutions extensively to provide distance education for young children during closures of early education schools/centres.

The G20, under Saudi Arabia's Presidency, entrusted the OECD with conducting a study to investigate how digital technologies were used to maintain continuity of education for young children in 2020 , as well as the challenges that countries faced in implementing distance education and the changes that the pandemic may bring to policies around the use of technology in early education.

This report syntheses findings from the responses of 34 countries to a policy survey collecting information on the role of digital technologies in response to the pandemic at the pre-primary level of education (typically, for children aged 3 to 6 ) and in the first years of primary education (typically, for children aged 7 to 8).

\section{Key findings}

In 2020, as the COVID-19 pandemic hit the world, countries followed a variety of strategies regarding the scope and length of closures of early education schools/centres. Whereas by mid-April 2020 schools/centres were fully or partially closed in most countries, by mid-November most countries had gradually brought back in-person education for young children. Across countries participating in the survey, full closures of pre-primary schools/centres lasted an average of 13 calendar weeks in 2020, while primary schools were fully closed for an average of 14 calendar weeks, with high variation between countries.

Prior to the pandemic, digital technologies were more extensively used as mode of communication rather than as pedagogical tools, and more extensively in primary than in pre-primary education. In the majority of countries participating in the survey, schools/centres and/or actors at the local level have major responsibilities regarding the choice of technologies and the approach to their integration in teaching and learning, generally within frameworks established by government.

As the pandemic hit the world in 2020, G20 and OECD countries were committed to maintaining continuity of education for young children. Pre-primary teachers were required to continue working during school/centre closures in $70 \%$ of the countries participating in the survey, and primary teachers in $86 \%$ of the countries.

The importance that different digital technologies played in maintaining continuity of education for young children in 2020 varied across countries. At both levels of education, materials shared with parents through digital channels to be then used without exposing children to screens were reported to have had a "major importance" in $60 \%$ of the participating countries. Digital solutions involving direct exposure to screens and including interactive or real-time functions were reported to have been more important in primary than in pre-primary education.

In most countries, the estimated amount of time that children were expected to spend using digital tools as part of distance education activities was low. In $80 \%$ of the countries with available data, real-time or interactive activities with peers and teachers for children in pre-primary classrooms were estimated to last less than one hour per day. 
At the pre-primary level, levels of use of real-time and interactive digital solutions for distance education in 2020 are generally associated with prior expectations that teachers integrate digital technologies in their work with children; at the primary level, where reliance on these solutions was greater in 2020, no association is visible.

Across countries, digital technologies were also used for maintaining communication with parents and families and supporting them in their role as educators. Moreover, more than half of the countries in the survey mobilised broadcast technologies as a complement to digital technologies in their efforts to provide distance education for young children in 2020. Less than half of participating countries gave priority to specific curricular areas or skills when providing distance education for young children.

At both levels of education, the main challenges encountered by countries related to the capacity of families to support distance education activities, to equipment and connectivity problems, and to a shortage of digital tools and content specifically designed for young children. Across countries, and at both levels of education, maintaining continuity of education was particularly challenging for children from socio-economically disadvantaged backgrounds and for children with special education needs. In responding to these challenges, about $40 \%$ of countries participating in the survey provided targeted support for socio-economically disadvantaged families to maintain children's learning at home. Another common measure was the provision of digital content adapted to special education needs.

Perceptions about the effectiveness of distance education in 2020 varied notably across countries, with many reporting a high level of uncertainty about such effectiveness. Meanwhile, the pandemic accelerated the adoption of measures to protect young children from potentially harmful uses of digital technology, including recommendations for teacher and parents about screen time for young children, advice to families about adult-supervised use of technology at home, and information on approaches to protect children's privacy and well-being in digital environments.

The pandemic acted also as a catalyst for rethinking policies regarding the use of digital technologies in early education. Both at the pre-primary and primary levels, more than $75 \%$ of countries participating in the survey reported having changed their approaches to integrating digital technologies in early education following the experience with distance education in 2020. Among the strategies envisaged to improve uses of digital technology up to 2025, countries' top priority is to strengthen training for early education professionals, followed by the development of digital learning tools specifically designed for young children.

\section{Policy pointers}

- Address the access digital divide in educational and home settings, ensuring that children across all socio-economic groups have equal opportunities to benefit from digital resources for learning.

- Strengthen professional development around digital technology for early education teachers, supporting them to gain a better understanding of and stronger skills for developmentally appropriate technology-supported activities with children, as well as for engaging with families and other work tasks.

- Improve co-operation between pre-primary education and the early years of primary education around how digital technologies can be best used for the education and development of young children.

- Consolidate measures to protect children in digital environments. Support teachers and parents in helping children to develop safe and informed uses of digital technology, both at home and in education settings.

- Improve mechanisms to assess the effectiveness of distance education, and the use of educational technologies more broadly, keeping a focus on the specific developmental stages of young children. 


\section{Background and rationale}

Children's experiences in their early years, including those in early education 1, are critical for building strong and equitable foundations for individual and societal outcomes. While digital technologies increasingly permeate the ways in which children live and learn, early education continues to operate with large uncertainties about the best policies for exploiting the opportunities and minimising the risks brought about by digitalisation. Within a developmentally appropriate framework, digital technologies may support a range of interactions in early education settings, including those among children and those between children and teachers, their families and the wider community. At the same time, the integration of digital technology in early education raises a number of substantial challenges. Most importantly, technology cannot replace the close personal interactions that young children require to meet their basic needs, ensure their safety and promote their learning and well-being $1 O E C D$, $\left.2021_{[1]}\right)$, and its use should enhance, rather than interfere with, the processes that are important for supporting young children's development and the work of early education professionals.

While the digitalisation trend has shaped education for many years, the COVID-19 pandemic drastically accelerated educations systems' reliance on digital solutions to meet the need of providing continuity of education while schools and early education centres remained closed in 2020 to protect the health of children, teachers, and their families, and to comply with broader social distancing and mobility restrictions. Amidst the massive disruption caused by the pandemic, countries turned to alternative pathways to ensure continued provision of education and digital resources became a lifeline for maintaining learning and social interaction opportunities for young children. With closures often being implemented at short notice to respond to the rapidly changing pandemic context, countries sought to bridge gaps in education delivery by building on existing digital tools or developing new ones, and teachers, children and families had to quickly adapt to teaching and learning online.

Undoubtedly, adapting to this new reality was difficult at all levels of education. Data from PISA 2018 reveals wide disparities both between and within countries in the availability of technology in secondary schools and of teachers' capacities to use those tools effectively $\left(O E C D, 2020_{[2]}\right]$. However, challenges were arguably greater in early levels of education given that in-person contact with teachers and carers is particularly important for young children and that traditional digital alternatives are least effective. Likewise, greater difficulties existed in providing distance education for children of disadvantaged backgrounds and children with special education needs, who tend to have more difficulty in accessing and using digital solutions. Moreover, differences in resources in home learning environments and in the capacity of education settings to support children remotely likely acted

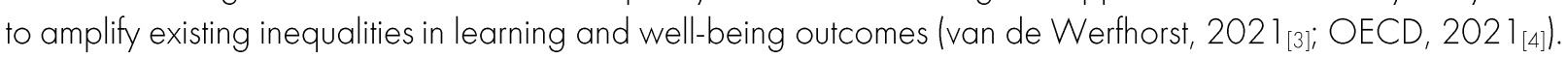

\footnotetext{
'Throughout this report, the term 'early education' is used to refer both to the pre-primary level of education and to the early years of primary education; the term 'young children' is used to refer to children in the typical age groups for these two levels of education 13 to 6 and 7 to 8 , respectivelyl; and the term 'early education teachers' is used to refer to teachers and staff working with children at these two levels of education.
} 
In 2020, countries had to respond to the COVID-19 pandemic as fast as they could, but the crisis brought to the forefront the need to engage in a deeper exploration of the benefits and risks associated with the use of digital technologies in the education of young children to inform future policy developments. A growing awareness of the possibility of other systemic shocks fuels ongoing debates about the changes required in education systems to prepare for the digital age and about the transformations brought by the pandemic. It is therefore of utmost importance that governments take stock of how digital technologies were used to maintain continuity of education for young children in 2020, not just to improve preparedness for short-term responses to other potential disruptions but, more importantly, to inform more robust approaches to using technology to enrich the educational experiences of young learners in the long run $\left(\mathrm{OECD}, 202 \mathrm{O}_{[5]} ; \mathrm{OECD}, 202 \mathrm{l}_{[6]}\right)$.

It is in this context that the G20, under Saudi Arabia's Presidency, entrusted the OECD with conducting a study to investigate how digital technologies were used in G20, OECD and partner countries to maintain continuity of education for young children in 2020, as well as the challenges that countries faced in providing distance education and the changes that the COVID-19 pandemic may bring to policies for the use of digital technology in early education. The study explored also the use of broadcast technologies as a complement to digital solutions in the provision of distance education.

Children across G20 and OECD countries attend different settings between the ages of 3 and 8 and the governance of the pre-primary and primary levels of education often follows under different ministries and agencies. As a result, many countries adopted different solutions to respond to the pandemic at each of these levels of education. The study therefore separately collected and analysed information relating to pre-primary education and the first years of primary education, while looking at opportunities to align approaches and improve transitions between the two levels.

The study does not address all the dimensions of the education policy responses to COVID-19 pandemic but draws on previous work by the OECD and other organisations covering a broader range of policy measures (OECD, $\left.202 \mathrm{O}_{[5]} ; \mathrm{OECD}, 202 \mathrm{l}_{[6]}\right]$. With its focus on the use of digital technologies in early education, the report identifies a number of examples to facilitate peer learning and disseminate good practices across G20 and OECD countries. While its findings should be interpreted with caution given the self-reported nature of the data, they constitute a first step towards building a body of evidence around the benefits and risks of using digital technologies in early education, to be extended by additional data collections and policy discussions in the years to come.

\section{Methodology and report structure}

Information on how G2O, OECD and partner countries used digital technologies to maintain continuity of education for young children in 2020 was gathered through a policy survey. The survey considered policies targeted at two groups: 1) children in pre-primary education and care services (ISCED Level 02), typically aged 3 until entry to primary school; and, 2) children in the first stage/early years of primary education (ISCED Level 1), typically aged 7 to 8 .

Data were collected between February and April 2021. The survey was sent to ministries of education and, where relevant and possible, other ministries or agencies with responsibilities for pre-primary education and the early years of primary education. G20, OECD and partner countries were asked to designate contact points for consolidating answers to the survey and sharing them with the OECD secretariat. Federal countries were offered the possibility to provide additional responses at the sub-national or sub-federal level (e.g. states, territories, länder). Given the complexity of the early education sector in some countries and jurisdictions, the survey focused on the settings that accommodate the majority of children in the respective age ranges. Further, respondents had the opportunity to report measures adopted at different periods of school/centre closures throughout 2020. Given that the first wave of closures in the Northern Hemisphere Spring of 2020 was the longest in most 
of the countries participating in the survey, unless otherwise indicated results presented in this report relate to the first period of school/centre closures in 2020 in each respective country.

The design of the survey benefited from valuable input from the OECD Early Childhood Education and Care Network, which has extensive expertise in the covered areas. The survey was administered online and consisted of 39 questions including multiple-choice, Likert-type scale and open-ended questions. Participant countries and jurisdictions were also invited to provide additional information and documentation in support of their responses to the questionnaire. Information was collected on a self-reporting basis.

In preparation for the analysis, data received from countries were cleaned and harmonised by the OECD Secretariat. Incomplete sets of responses to the survey were excluded from the final version of the dataset. Unless otherwise stated, response categories "Not known" and "Not applicable" were coded as missing values in individual questions. The total number of observations $(N)$ reported in tables and figures excludes missing and invalid values, and it may differ between the two levels of education for the same question. Footnotes to tables and figures indicate instances when the analysis restricted valid observations to specific response categories.

The findings presented in this report are based on the survey responses submitted by $13 \mathrm{G} 20$ member countries (Argentina, Australia, Canada, France, Germany, India, Italy, Japan, Korea, Russian Federation, Saudi Arabia, Turkey and the United Kingdom²) as well as by 19 OECD countries (Austria, Belgium [Flanders] ${ }^{3}$, Chile, Colombia, Czech Republic, Denmark, Estonia, Finland, Iceland, Ireland, Lithuania, Luxembourg, Netherlands, New Zealand, Norway, Portugal, Slovak Republic, Spain-also a permanent G20 guest country - and Switzerland), by 1 G20 guest country (Singapore) and by 1 sub-national jurisdiction (State of Queensland, Australia) 4,5. Figure 1.1 provides a breakdown of the participation of countries and jurisdictions at the pre-primary and primary levels of education.

Designed for government officials with responsibilities in early education, the survey collected information on national or regional education policy responses to the COVID-19 pandemic. Its findings are thus to be understood as reflecting system-level policy directions rather than specific implementations at the local or school/centre levels.

This synthesis report is structured around the main areas covered by the survey:

- duration and scope of school/centre closures in 2020

- approaches to the use of digital technologies in early education prior to the pandemic

- maintaining continuity of education for young children in 2020

- challenges and adaptations

- supporting vulnerable groups of young children

- strategies going forward.

\footnotetext{
2 The survey questionnaire required one response from the United Kingdom. Where responses for individual countries (England, Northern Ireland and Wales) diverged, a response was entered for the most common approach across the three countries, with explanatory notes added to explain any divergence.

${ }^{3}$ Responses refer only to the Flemish Community of Belgium.

${ }^{4}$ Survey responses from the State of Queensland may not be reflective of experiences across all Australian States and Territories where the impact of COVID-19 differed markedly, including periods of lockdowns and school closures.

${ }^{5}$ For convenience, the report generally refers to survey respondents as 'countries', but responses from sub-national jurisdictions are also included in the analyses.
} 


\section{1 Duration and scope of closures of early education centres and schools in 2020}

\section{Key messages}

- In 2020, as the COVID-19 pandemic hit the world, countries followed a variety of strategies concerning the scope and length of early education school/centre closures.

- Full or partial schools/centres closures were reported by 25 out of 30 countries at the pre-primary level and by 28 out of 29 countries at primary level of education. Among the few countries that did not order school/centre closures are Estonia and Iceland at the pre-primary level, and Saudi Arabia where schools at both levels remained open throughout 2020.

- Countries gradually brought back in-person education for young children. At the pre-primary level of education, whereas by mid-April 2020 schools/centres remained open in only $17 \%$ of the participating countries, by mid-November 2020 they were open in $77 \%$ of the countries. In primary education, by mid-April 2020 schools remained open in $7 \%$ of the countries while six months later they were open in $64 \%$ of the countries.

- On average across the countries participating in the survey, pre-primary schools/centres were fully closed for 13 calendar weeks in 2020, while primary schools were fully closed for 14 calendar weeks. However, these averages mask substantial variation across countries. At the pre-primary level, the longest periods of closure (in weeks) were reported by Chile (25) and Colombia (24). At the primary level, the longest closures were reported by Colombia (42), India (37) and Argentina (24).

Early education settings and schools are central to the daily lives of young children. However, when the global COVID-19 epidemic hit the world in 2020, many countries resorted to widespread closures of schools/centres and ordered children to stay at home in order to reduce the transmission of the virus. While, understandably, public health considerations took precedence, decisions to close schools/centres have a number of potential social and economic risks, including, among others, learning losses, rising dropout rates, social isolation or increased

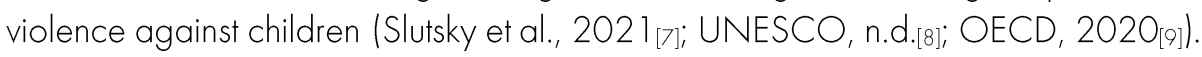

Results from the OECD Survey on Distance Education for Young Children in 2020 (hereafter the survey) show that in 2020 most participating countries decided to fully or partially close schools/centres for young children: closures were reported by 25 out of 30 countries at the pre-primary level and by 28 out of 29 countries at primary level of education (Figure 1.1). Among the countries that did not order school/centre closures are Estonia, Iceland and Japan, at the pre-primary level, while Saudi Arabia allowed schools/centres at both levels to remain open throughout 2020. 
Figure 1.1. Closure of early education schools/centres in 2020

Country reports on whether closures occurred in 2020 , by level of education

\begin{tabular}{|c|c|c|c|}
\hline & \multirow[t]{2}{*}{ Participation in the survey } & \multicolumn{2}{|c|}{ School/centre closure (either fully or partially) in 2020} \\
\hline & & Pre-primary & Primary \\
\hline Argentina* & Primary (ISCED 1) & $\mathrm{m}$ & Yes, schools were closed \\
\hline Australia $^{*}$ & Both levels & Yes, schools/centres were closed & Yes, schools were closed \\
\hline Australia (Queensland)* & Primary (ISCED 1) & $\mathrm{m}$ & Yes, schools were closed \\
\hline Austria & Both levels & Yes, schools/centres were closed & Yes, schools were closed \\
\hline Belgium (Flanders) & Both levels & Yes, schools/centres were closed & Yes, schools were closed \\
\hline Canada* $^{*}$ & Both levels & Yes, schools/centres were closed & Yes, schools were closed \\
\hline Chile & Pre-primary (ISCED 02) & Yes, schools/centres were closed & $\mathrm{m}$ \\
\hline Colombia & Both levels & Yes, schools/centres were closed & Yes, schools were closed \\
\hline Czech Republic & Both levels & Yes, schools/centres were closed & Yes, schools were closed \\
\hline Denmark & Both levels & Yes, schools/centres were closed & Yes, schools were closed \\
\hline Estonia & Both levels & No, schools/centres remained open & Yes, schools were closed \\
\hline Finland & Both levels & Yes, schools/centres were closed & Yes, schools were closed \\
\hline France $^{*}$ & Both levels & Yes, schools/centres were closed & Yes, schools were closed \\
\hline Germany* & Pre-primary (ISCED 02) & Yes, schools/centres were closed & $\mathrm{m}$ \\
\hline Iceland & Pre-primary (ISCED 02) & No, schools/centres remained open & $\mathrm{m}$ \\
\hline India* ${ }^{*}$ & Primary (ISCED 1) & $\mathrm{m}$ & Yes, schools were closed \\
\hline Ireland & Both levels & Yes, schools/centres were closed & Yes, schools were closed \\
\hline Italy* & Both levels & Yes, schools/centres were closed & Yes, schools were closed \\
\hline Japan $^{*}$ & Both levels & No, schools/centres remained open & Yes, schools were closed \\
\hline Korea $^{*}$ & Both levels & Yes, schools/centres were closed & Yes, schools were closed \\
\hline Lithuania & Both levels & Yes, schools/centres were closed & Yes, schools were closed \\
\hline Luxembourg & Pre-primary (ISCED 02) & Yes, schools/centres were closed & $\mathrm{m}$ \\
\hline Netherlands & Primary (ISCED 1) & $\mathrm{m}$ & Yes, schools were closed \\
\hline New Zealand & Both levels & Yes, schools/centres were closed & Yes, schools were closed \\
\hline Norway & Both levels & Yes, schools/centres were closed & Yes, schools were closed \\
\hline Portugal & Both levels & Yes, schools/centres were closed & Yes, schools were closed \\
\hline Russian Federation* & Both levels & Yes, schools/centres were closed & Yes, schools were closed \\
\hline Saudi Arabia* & Both levels & No, schools/centres remained open & No, schools remained open \\
\hline Singapore ${ }^{\star \star}$ & Both levels & Yes, schools/centres were closed & Yes, schools were closed \\
\hline Slovak Republic & Both levels & Yes, schools/centres were closed & Yes, schools were closed \\
\hline Spain ${ }^{* *}$ & Both levels & Yes, schools/centres were closed & Yes, schools were closed \\
\hline Switzerland & Pre-primary (ISCED 02) & Yes, schools/centres were closed & $\mathrm{m}$ \\
\hline Turkey* & Both levels & Yes, schools/centres were closed & Yes, schools were closed \\
\hline United Kingdom* & Both levels & Yes, schools/centres were closed & Yes, schools were closed \\
\hline
\end{tabular}

* G20 member countries are indicated with an asterisk.

** G20 guest countries are indicated with a double asterisk.

Note: In Japan, the majority of primary schools were closed between March and May 2020, though the decision about school closures was made primarily at the local level and not at the national level.

Source: OECD Survey on Distance Education for Young Children in 2020.

However, countries followed various strategies regarding the scope and length of school/centre closures. The survey defined interruptions of in-person schooling as "full" closures when government-mandated and/or recommended closures of schools/centres premises affected all or most of the children/student population enrolled at a given level of education, acknowledging that various distance education strategies could be deployed to maintain continuity of education. In turn, school/centre closures were defined as "partial" when government-mandated or/and recommended (a) partial (re)-opening in certain areas, and/or (b) a phased (re)-opening by grade level or age and/or (c) the use of a hybrid model combining in-person at school/centre and distance education. Partial closures included also situations in which national governments deferred decisions on (re-)opening to other administrative units (e.g. region, municipality or individual schools/centres), and where a variety of (re-) lopening modalities were used. 
Figure 1.2 shows that most countries opted for a single period of either "full" or "partial" school/centre closures in 2020, and that a small number of countries enacted a second or third period of closure.

\section{Figure 1.2. Scope of early education school/centre closures in 2020}

Number of countries reporting periods of closure and type of closures (full or partiall), by level of education

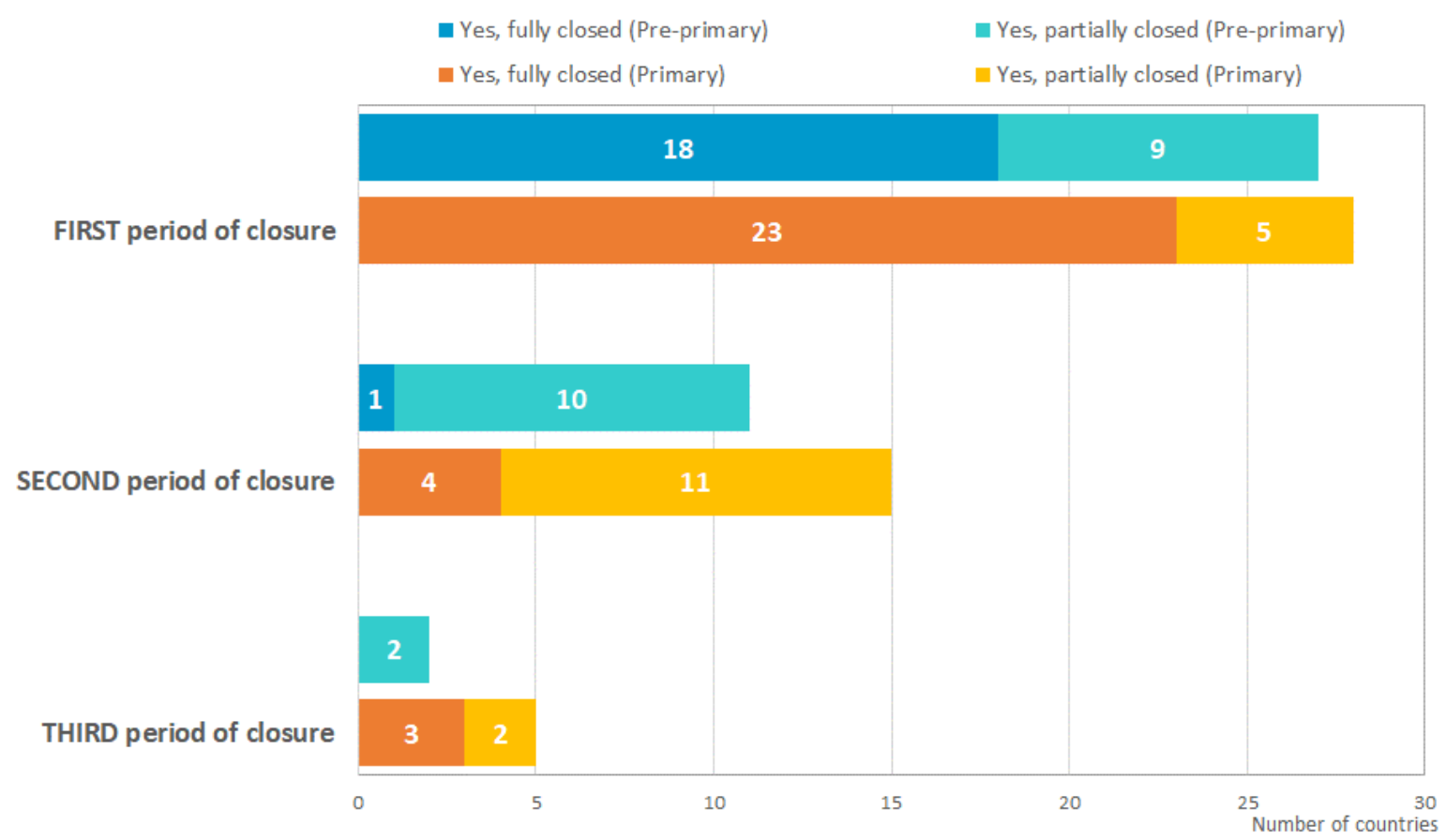

Notes: "Full" closures are defined as government-mandated and/or recommended closures of schools/centres premises affecting all or most of the children/student population enrolled at a given level of education. "Partial" closures are defined as government-mandated or/and recommended (a) partial (re)-opening in certain areas, and/or (b) a phased (re)-opening by grade level or age and/or (c) the use of a hybrid model combining in-person at school/centre and distance education. This includes also contexts where national governments deferred decisions about (re-lopening to other administrative units (e.g. region, municipality), and where a variety of (re-)opening modalities were used.

Source: OECD Survey on Distance Education for Young Children in 2020.

\section{Box 1.1. Examples from G20: Circumstances of school/centre closure}

Figure 1.2 shows that countries combined different approaches when closing their early education schools/centres. Survey respondents were asked to describe the circumstances under which staff or children were allowed to be present at schools/centres. For instance, countries could specity partial (re)-openings in certain areas, phased (re)-openings by grade level or age, or the use of hybrid models combining in-person and distance education.

In Germany, in the early months of the pandemic, pre-primary schools/centres started with a period of full closure (from 16 March 2020 to 1 July 2020) where only children of parents working in key sectors were allowed to attend emergency childcare ("Notbetreuung"). From mid-April onwards a re-opening process was gradually introduced, the pace of which varied across federal states. In this re-opening, additional groups were received in the centres (e.g. children of single parents; children from disadvantaged backgrounds). For children not attending early childhood education, some centres offered online or offline learning materials. 
As of July 2020 and onwards, most centres were operating in full under COVID- 19 safety protocols (e.g. regular window opening in rooms, minimisation measures such as separating groups).

Countries in the United Kingdom followed various approaches to school/centre closures. In Northern Ireland, pre-school settings and primary schools remained open for vulnerable children and children of key workers, but attendance levels were low and measures to maintain safety and hygiene were in place. The majority of children were engaged in distance learning. In Wales, non-maintained settings (i.e. not government-funded) were predominantly closed but a small number remained open to care for the children of critical workers and vulnerable children. In England, from 22 June, non maintained settings gradually re-opened, leading to full re-opening by Autumn 2020.

Source: OECD Survey on Distance Education for Young Children in 2020.

As an attempt to curb the first wave of the pandemic, most of the surveyed countries closed all or most of their schools/centres from mid-March to mid-May or mid-June 2020, but gradually re-opened them in the second half of the year (Figure 1.3) (OECD, $\left.2021_{[6]}\right)$.

By 15 April 2020, pre-primary schools/centres were "fully" closed in 57\% of the countries participating in the survey (e.g. France, Germany, Italy, Singapore, Spain and Turkey), while schools for the early years of primary education were "fully closed" in $76 \%$ of the countries (e.g. Canada, France, Italy, Japan and Spain). About a fourth of the countries decided on partial closures at the pre-primary level (e.g. Australia and Russian Federation), as well as in the early years of primary education (e.g. India, Korea, Russian Federation, Singapore and Turkey). However, most countries changed their position about the scope of school/centre closures throughout 2020. At the pre-primary level of education, whereas by 15 April 2020 schools/centres remained open in only $17 \%$ of the participating countries, by 15 November 2020 they were open in $77 \%$ of the countries. For example, France, Norway, Singapore and Spain adopted "full" school closures by 15 April, but their pre-primary schools/centres had resumed in-person education by mid-November. It was only Estonia, Iceland, Japan and Saudi Arabia that did not adopt nation-wide closures of their pre-primary schools/centres, while Turkey was the single country opting for "full" closures at multiple periods.

At the primary level of education, by 15 April 2020, schools remained open in $7 \%$ of the countries while six months later, by 15 November 2020, they were open in 64\% of the countries. Countries such as Estonia, France and New Zealand closed their primary schools in the first half of the 2020, but re-opened them in the second half of 2020. In Canada, in two provinces, schools re-opened for a few weeks in May/June 2020. Partial closures of primary schools from April to November 2020 were reported in Austria, Denmark, India, Norway and Turkey, while full closures over the same period were reported by the Czech Republic and the Netherlands. 
Figure 1.3. Closures of schools/centres by 15 April and 15 November 2020

Percentage of countries reporting full or partial closures, by level of education
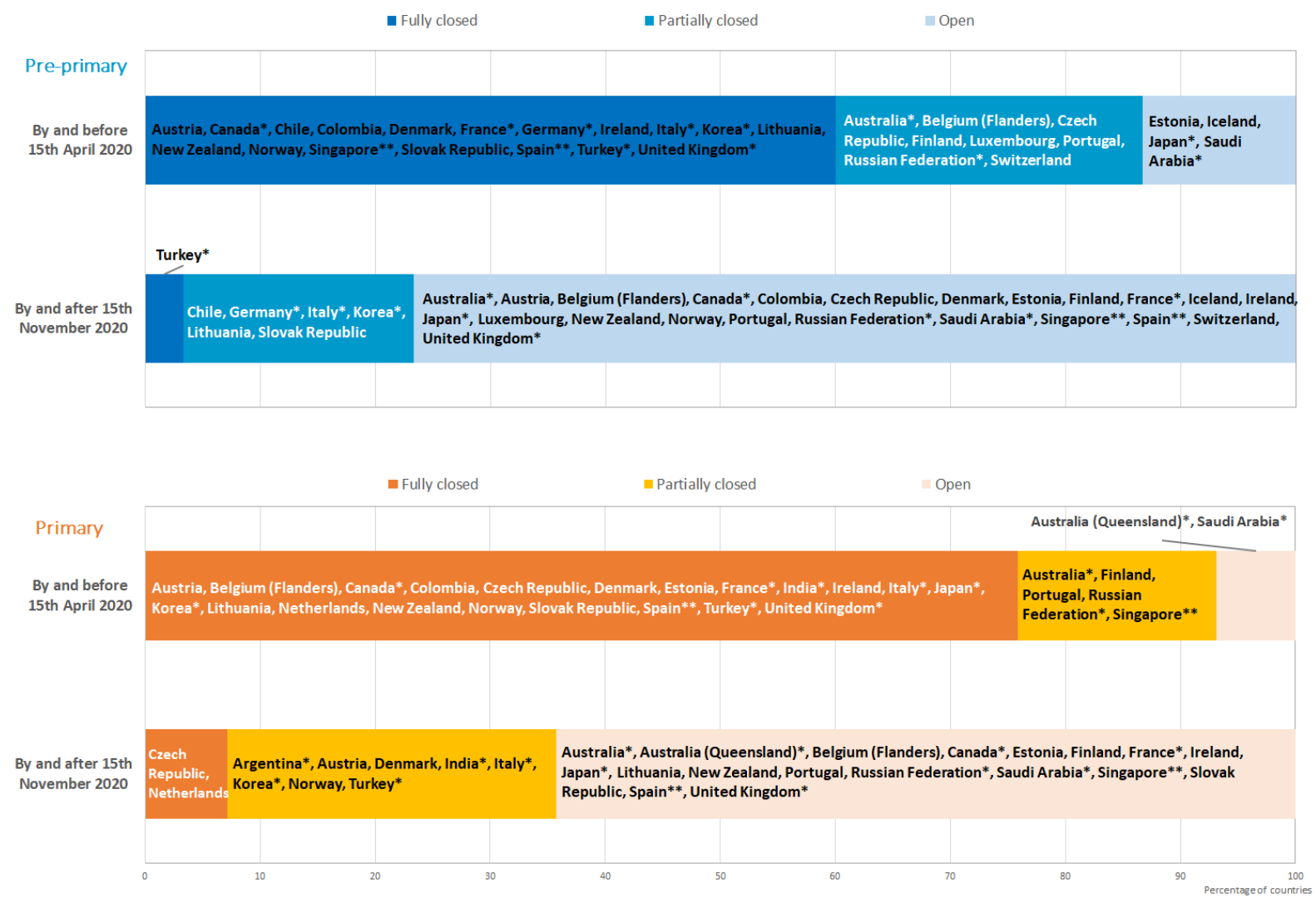

* G20 member countries are indicated with an asterisk.

** G20 guest countries are indicated with a double asterisk.

Notes: The analysis is based on the starting and ending dates of full school/centre closure as indicated by countries. For definitions, see notes to Figure 1.2.

Source: OECD Survey on Distance Education for Young Children in 2020.

Whereas all types of closures caused some disruption to the functioning of early education settings and schools, it was arguably "full" closures that brought greater risks of learning losses and limited social interaction for children. Throughout 2020, and across all the countries participating in the survey, pre-primary schools were "fully" closed for an average of 13 weeks, while primary schools were "fully" closed for an average of 14 weeks (including weekends and public holidays). These averages, however, mask substantial variation across countries. At the pre-primary level, countries that "fully" closed their schools/centres for at least 20 weeks include Chile (25) and Colombia (24), whereas countries where closures lasted 10 weeks or less include France (8), Singapore (8), Norway (6), New Zealand (5) and Denmark (4). At the primary level, the longest closures, lasting 20 weeks or longer, were reported by Colombia (42), India (37) and Argentina (24), while the shortest, of 10 weeks or less, were reported by Estonia (9), Belgium (Flanders) (8), France (8), Korea (7), Norway (7), New Zealand (5), Australia (Queensland) (5) and Japan (4) (Figure 1.4). 
Figure 1.4. Length of full closures of early education schools/centres in 2020 due to the COVID-19 pandemic

Estimated number of calendar weeks of "full" closures throughout 2020, by level of education

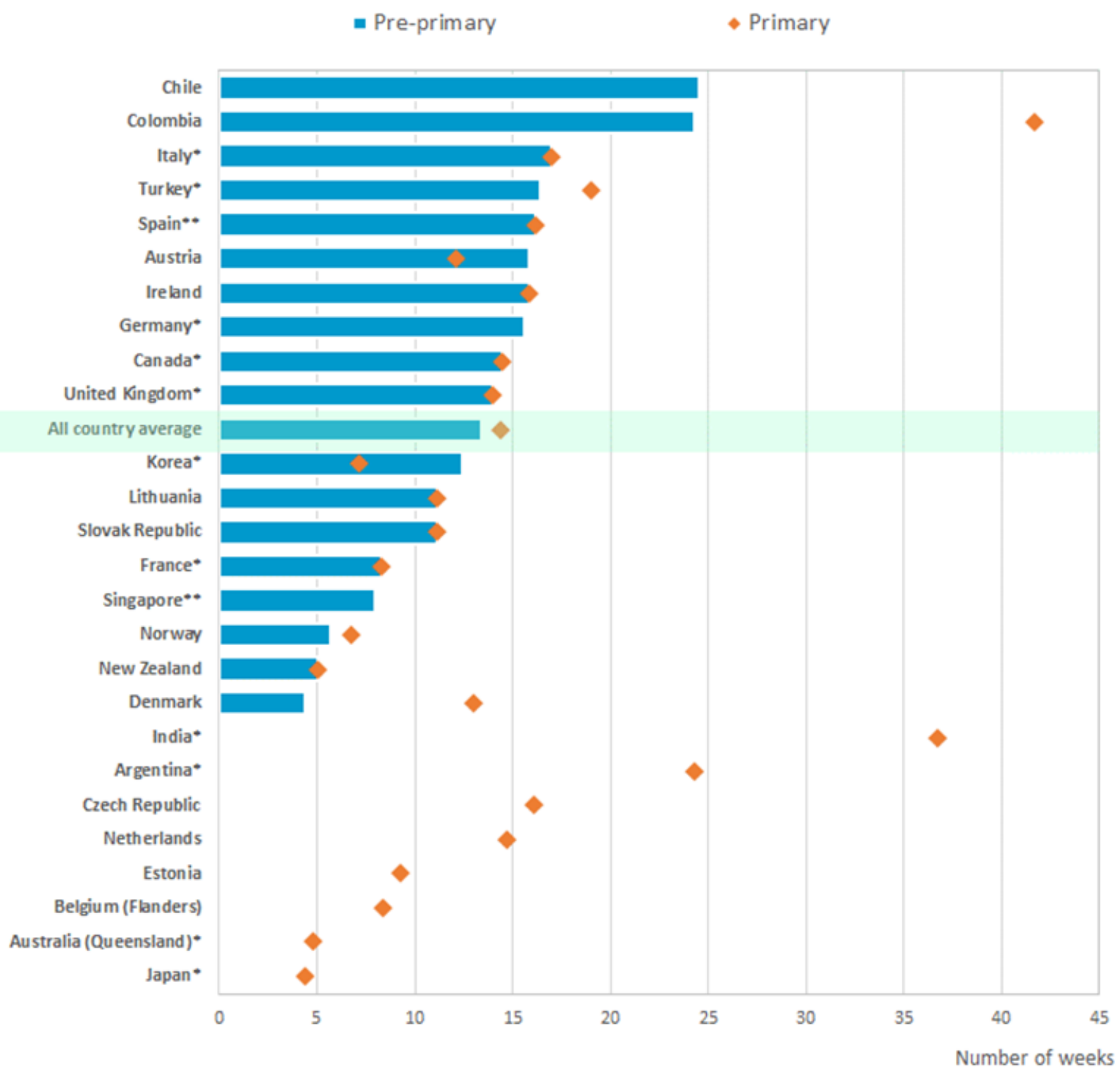

* G20 member countries are indicated with an asterisk.

** $\mathrm{G} 20$ guest countries are indicated with a double asterisk.

Notes: Only countries with full school/centre closures at any of the reported education levels are shown. In Iceland and Saudi Arabia, schools/centres remained open. The analysis is based on starting and ending dates of periods of full school/centre closures (including weekends, public and school holidays) as indicated by countries. Due to variation in school year calendars across countries, the results are an approximate estimate of the length of interruptions of in-person education in 2020. For definitions, see notes to Figure 1.2. Countries are sorted in descending order by the number of weeks when pre-primary schools/centres were fully closed throughout 2020. Source: OECD Survey on Distance Education for Young Children in 2020. 


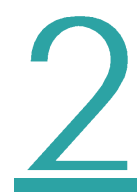

\section{Approaches to the use of digital technology in early education prior to the pandemic}

\section{Key messages}

- Prior to the pandemic, in early education digital technologies were more commonly used as communication than as pedagogical tools, with wide variation across countries in the extent to which digital tools were integrated in teaching practices. Countries generally reported higher exposure of children to digital technologies in primary than in pre-primary education.

- Many countries, including Belgium (Flanders), Finland, France, Korea, Lithuania, New Zealand, Norway, Spain, Saudi Arabia and the United Kingdom reported that, prior to 2020, a moderate expectation existed for both pre-primary and primary teachers to use digital technologies in their work with children.

- The majority of countries in the survey reported that the main responsibility for decisions regarding the choice of technology tools and of approaches for their integration in teaching and learning lies with schools/centres and/or at the local level, often in consultation with and/or within frameworks established by higher levels of government.

Over the past decade, digital devices have become increasingly present in children's daily lives from a very early age. Many countries have already introduced programmes to address digitalisation in young children's education (Sepúlveda, 2020[10] ) with substantial variation in policies partly reflecting ongoing debates about the costs and benefits of using digital tools in the early years (European Commission, 2019[11]; Gottschalk, 2019[12]). Lessons learnt from the COVID-19 pandemic, though, may transform the way in which policy-makers, teachers and families perceive the role of digital technologies in the future of education, and an opportunity to re-evaluate existing approaches on the use of digital technologies in early education.

The survey collected information about the different purposes for which countries used digital technologies in early education schools/centres prior to the pandemic, adopting a broad definition of digital technologies that encompasses digital devices and the access they allow to both the Internet and digital resources (including applications, social networking, and games). At both the pre-primary and primary levels of education, more than $80 \%$ of participating countries reported that digital technologies were already being used as communication tools with parents to a "great" or "moderate" extent prior to 2020 (Figure 2.1). 
A majority of countries (76\%) also indicated that digital tools were used as pedagogical tools in pre-primary schools/centres to a "great" or "moderate" extent; that at the pre-primary level children were routinely exposed to digital technologies (63\%); and that pre-primary teachers were expected to use digital technologies for their work $(60 \%)$. By contrast, more than $75 \%$ of countries reported that digital technologies were used for all these purposes to a "great" or "moderate" extent in primary schools already prior to the pandemic.

\section{Figure 2.1. Uses of digital technologies in early education prior to the COVID-19 pandemic}

Percentage of countries reporting different levels of intensity/exposure, by level of education

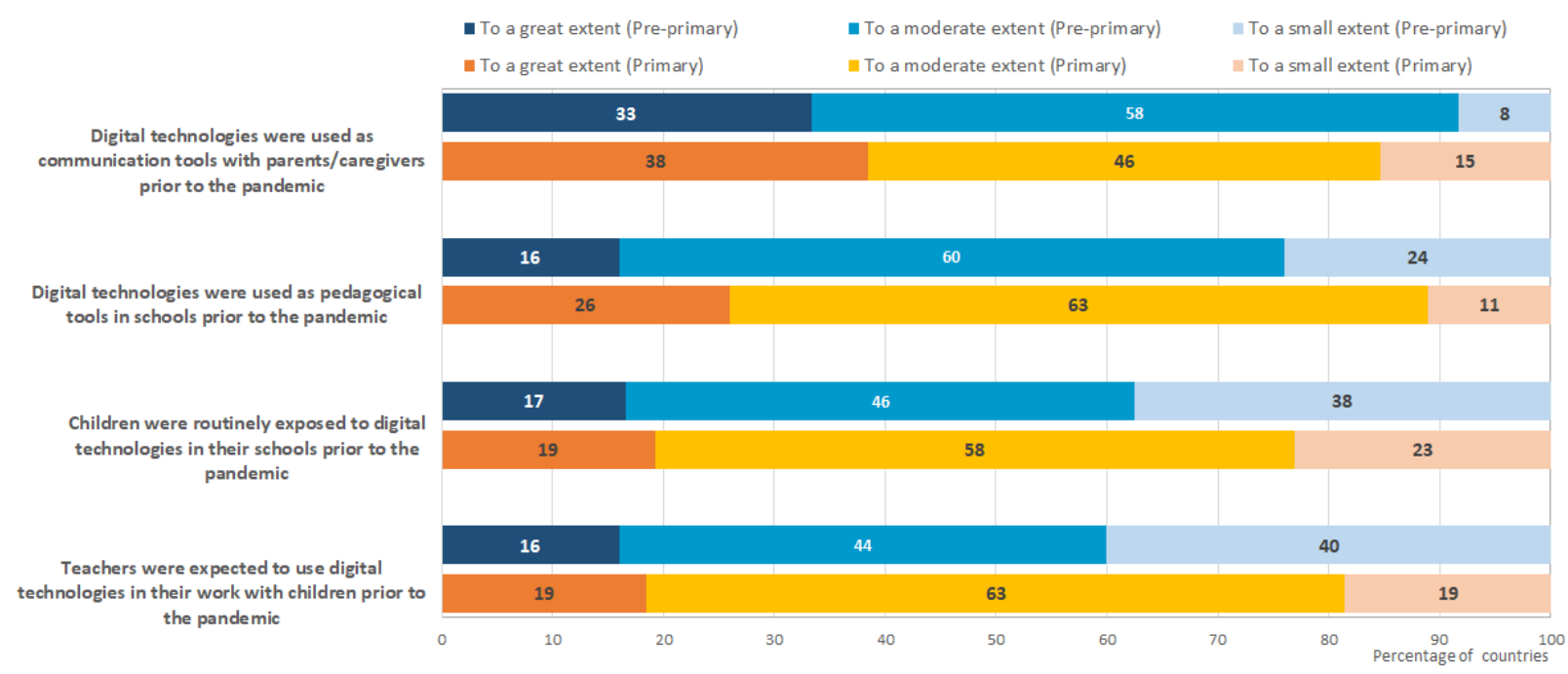

Notes: Only countries with displayed response categories are included in the analysis (i.e. "not at all", "not known" and "not applicable" are excluded from the percentages). Items are sorted in descending order by the sum of response categories "to a great extent" and "to a moderate extent" at the pre-primary level of education.

Source: OECD Survey on Distance Education for Young Children in 2020.

There is variation across countries, however, in how the use of digital technologies as pedagogical or communication tools compared between the two levels of education prior to the pandemic (Figure 2.2). For instance, Canada, Japan and Saudi Arabia reported substantial use of digital technologies as pedagogical tools in schools/centres at both levels of education, while Singapore reported low use at the pre-primary level and extensive use in the first years of primary education. The extent of use for communication purposes tends to be more consistent between the two levels in most countries, being also high in Estonia and Norway, in addition to Canada, Japan and Saudi Arabia, and low in Spain. Reports on children's exposure to digital technologies in early education schools/centres prior to the pandemic reveal similarly diverse approaches. At both levels of education, Japan and Saudi Arabia reported great exposure while the Czech Republic and Lithuania reported low levels of exposure. In Colombia, children's exposure to digital technologies was reported to be high in pre-primary settings and low in the early stages of primary education, while the opposite holds for Singapore.

Many countries, including Belgium (Flanders), Finland, France, Korea, Lithuania, New Zealand, Norway, Spain, Saudi Arabia and the United Kingdom reported that, prior to the pandemic, teachers were moderately expected to use digital technologies in their work with children aged 3 to 6 years old, as well as with children aged 6 to 8 . Estonia and Japan are the only countries reporting that the expectation was high at both levels prior to 2020 . By contrast, in Australia, Ireland and Singapore, the expectation was high for teachers in the early years of primary education but low for pre-primary teachers. 
Figure 2.2. Country profiles in the use of digital technologies in early education prior to the COVID-19 pandemic

Levels of intensity/exposure of different uses, by level of education

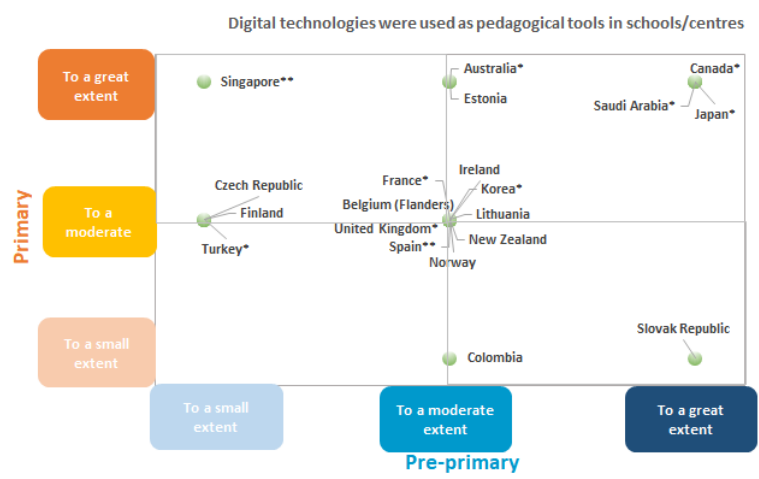

Children were routinely exposed to digital technologies in their schools/centres

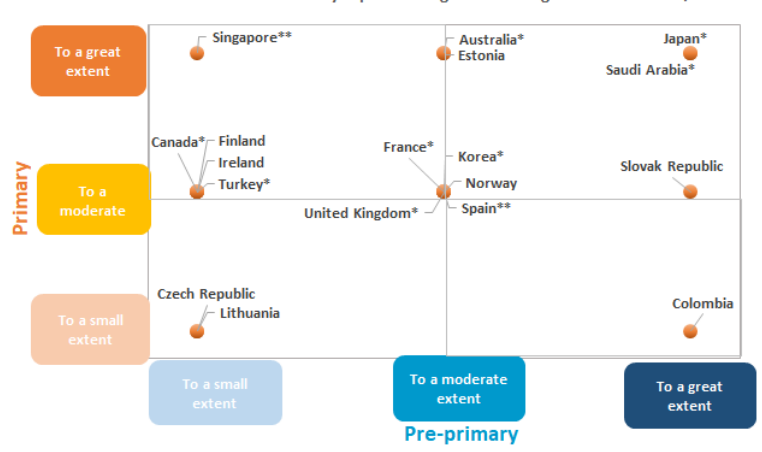

* G20 member countries are indicated with an asterisk.

* *20 guest countries are indicated with a double asterisk.

Note: Only countries with comparable data at both levels of education are shown.

Source: OECD Survey on Distance Education for Young Children in 2020.

In order to gain a better understanding on how digital technologies were used to continue the education for young children during the pandemic, the survey collected information about the locus of decision-making regarding the choice of technology tools and of approaches for integrating technology in teaching and learning practices in early education.

The majority of participating countries reported that the main responsibility for these decisions lies with schools/school boards or at multiple levels simultaneously, for instance with local actors in consultation with or after delegation from a higher level of government, and typically within a pre-established framework. For example, 43\% of countries (e.g. Australia, Canada, Singapore and United Kingdom) indicated that decisions about the use of technology to support learning in pre-primary education were taken at multiple levels, and $31 \%$ of countries (e.g. Argentina, Canada and Italy) reported similarly shared responsibilities in the early years of primary education (see Box2.1 for examples about the practical meaning of these multiple levels of responsibility). Pre-primary schools, school boards or local committees were reported to make decisions about the choice of specific digital tools/contents in $46 \%$ of the countries, including Estonia, Japan, or Italy. A higher share of countries reported that primary schools were responsible for the choice of digital content for teaching (Figure 2.3). 
In around $20 \%$ of the participating countries, central government was primarily responsible for choosing technology tools and the approaches for their integration in teaching and learning at both levels of education. Among others, central governments in France, Saudi Arabia and Turkey were reported to have a leading role in these respects. By contrast, Colombia and Switzerland reported that such responsibilities lied with sub-regional and local authorities.

Figure 2.3. Locus of responsibility regarding the use of digital technology in early education Percentage of countries reporting the level of governance making decisions "in practice", by level of education

\begin{tabular}{|c|c|c|c|c|c|c|}
\hline \multirow[b]{2}{*}{ Pre-primary } & \multicolumn{2}{|c|}{ In School, school board or committee } & Multiple levels & \multicolumn{3}{|c|}{ Central government } \\
\hline & & & & & Korea* - & Switzerland \\
\hline $\begin{array}{l}\text { Responsibility } \\
\text { about the choice } \\
\text { of specific digital } \\
\text { tools/contents }\end{array}$ & \multicolumn{2}{|c|}{$\begin{array}{l}\text { Belgium (Flanders), Chile, Czech Republic, Germany*, Iceland, Italy*, } \\
\text { Japan*, Lithuania, New Zealand, Norway, Portugal, Russian } \\
\text { Federation*, Singapore**, Slovak Republic }\end{array}$} & \multicolumn{2}{|c|}{$\begin{array}{l}\text { Australia*, Austria, Canada*, Denmark, } \\
\text { Estonia, Finland, France*, Korea*, } \\
\text { Spain**, United Kingdom* }^{*}\end{array}$} & $\begin{array}{l}\text { Ireland, } \\
\text { Luxembourg, Saudi } \\
\text { Arabia*, Turkey* }\end{array}$ & \\
\hline & & & & & Korea* & Switzerland \\
\hline \multirow[t]{2}{*}{$\begin{array}{l}\text { Responsibility } \\
\text { about the use of } \\
\text { technology to } \\
\text { support learning }\end{array}$} & $\begin{array}{l}\text { Czech Republic, Germany*, Iceland, } \\
\text { Japan*, Lithuania, New Zealand, } \\
\text { Russian Federation*, Spain** }\end{array}$ & \multicolumn{2}{|c|}{$\begin{array}{l}\text { Australia*, Austria, Belgium (Flanders), Canada*, Chile, } \\
\text { Denmark, Estonia, Finland, Italy*, Korea*, Singapore**, } \\
\text { Slovak Republic, United Kingdom* }\end{array}$} & \multicolumn{2}{|c|}{$\begin{array}{l}\text { France*, Ireland, Luxembourg, } \\
\text { Norway, Portugal, Saudi Arabia*, } \\
\text { Turkey* }\end{array}$} & \\
\hline & & & & & & Colombia \\
\hline
\end{tabular}

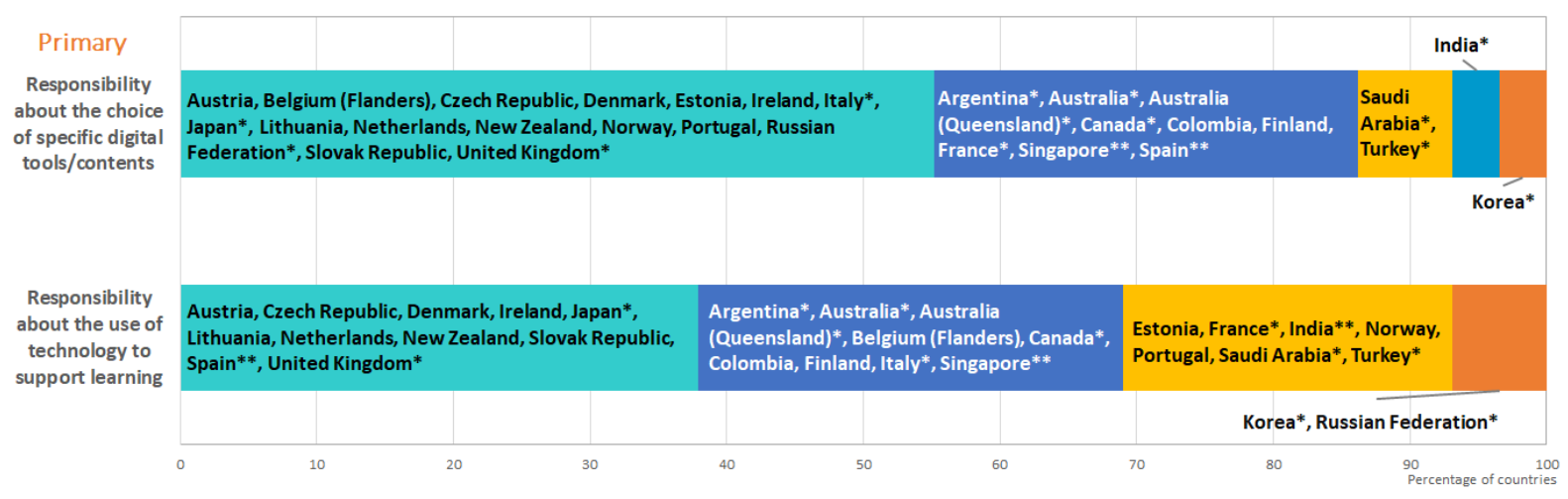

* G20 member countries are indicated with an asterisk.

** G20 guest countries are indicated with a double asterisk.

Note: Only countries with displayed response categories are included in the analysis (i.e. "not applicable" excluded from the percentages). Source: OECD Survey on Distance Education for Young Children in 2020. 
Box 2.1. Examples from G20 member countries: Multiple levels of decision-making regarding the use of digital technologies in early education

As shown in Figure 2.3, at least one-third of countries participating in the survey reported that the locus of decision-making about the use of digital tools in pre-primary education and in the first years of primary education occurs at multiple levels. This shared responsibility, however, adopts a specific configuration in each country. The examples below illustrate the diversity of these approaches.

In Australia, state and territory governments and approved non-government education authorities may support particular digital technologies and/or resources for use in schools, but decisions about how these technologies or resources are used to support student learning are made at multiple levels depending upon where responsibility for implementation sits in the organisation.

In Canada, decisions about the use and the choice of technology are made at the local level at each level of education. Depending on the technology in question, these decisions can be made at the level of the provincial/territorial Ministry of Education, the school board level, or at the classroom level by individual teachers.

In Singapore, the Ministry of Education provides schools with broad policy guidance, rolls out national initiatives and provides teacher professional development, technical infrastructure lincluding the Singapore Student Learning Space online learning platform) and security support to facilitate the effective use of education technologies in teaching and learning. Schools have the autonomy to select educational technology solutions and resources available on the market, based on their school and student needs.

Source: OECD Survey on Distance Education for Young Children in 2020. 


\section{Maintaining continuity of education for young children in 2020}

\section{Key messages}

- In about three-quarters of the countries participating in the survey, the "main" responsibility for organising alternative educational arrangements in the exceptional context of the COVID-19 pandemic relied at the school/centre and/or local level.

- The survey provides evidence of the commitment of G2O and OECD countries to maintain continuity of education for young children in 2020. Pre-primary teachers were required to continue working during school/centre closures in $70 \%$ of the participating countries, and primary teachers in $86 \%$ of the countries.

- There is a large variation in the importance that different types of digital technologies played across countries in maintaining education of young children in 2020. At both levels of education, digital materials shared digitally with parents/caregivers to be used without exposing children to screens were reported to have had a "major importance" by about $60 \%$ of participating countries. Digital technologies involving direct exposure of children to screens with interactive functions and/or enabling real-time activities were generally reported to have been more important in primary education than in pre-primary education.

- The estimated amount of time that children had to spend with digital technologies as part of distance education activities in 2020 was generally low and higher for children in primary education than for children in pre-primary education. In about $80 \%$ of countries with available data, children in pre-primary classrooms were expected to spend less than one hour per day on digitally-enabled real-time or interactive activities with peers and teachers.

- At the pre-primary level, there is a weak association between prior expectations that teachers integrate digital technologies in their work with children and the use of real-time and interactive digital solutions in 2020; no association with prior expectations is observed at the primary level, where reliance on this type of solutions was greater in 2020.

- Less than half of the countries participating in the survey prioritised specific areas of their pre-primary or primary curricula when providing distance education for young children in 2020.

- Digital technologies were also used by countries for maintaining communication with parents and families and supporting them in their role as educators. The share of countries reporting that digital technologies had a major role for maintaining relationships between parents and teachers was larger at the primary than at the pre-primary level.

- More than half of the countries in the survey mobilised broadcast technologies as a complement to digital technologies in their efforts to provide distance education for young children in 2020. Most often, this took the form of new TV programmes especially designed to support children's education during school/centre closures. 
This section explores how countries responded to the COVID-19 pandemic to maintain continuity of education for young children in 2020. The section examines first how countries organised responsibilities and requirements for implementing distance education. It then looks at the types of technologies that were mobilised, and at whether countries chose to prioritise specific areas of the curriculum in remote learning.

\section{Responsibilities and work requirements during school/centre closures}

While coordination between central government and school/centre or local level actors remained the norm, it was the latter who were primarily responsible for organising alternative education arrangements during the first wave of school/centre closures in 2020, and more often so at the pre-primary than at the primary level of education. Within a broad range of governance models, results indicate that, at both levels of education, the "main" responsibility for organising alternative arrangements in the exceptional context of the COVID-19 pandemic relied at the school/local level for about three-quarters of the countries participating in the survey. This includes countries where schools/centres took the leading role in organising alternative arrangements, with guidance from central government $(50 \%$ at the pre-primary level, and $54 \%$ at the primary levell); countries where new arrangements varied based on the type of schools/centres (e.g. public/private) or the state/regional government level (e.g. sub-national jurisdiction) ( $12 \%$ and $14 \%$, respectively); and countries where schools/centres had a more substantial degree of autonomy for deciding on such arrangements (15\% and $4 \%$, respectively). By contrast, central government had the "main" responsibility for alternative arrangements at the pre-primary level in 19\% of the participating countries, and for alternative arrangements at the primary level in $29 \%$ of the countries (Figure 3.11).

Figure 3.1. Locus of responsibility for organising alternative education arrangements during school/centre closures in 2020

Percentage of countries where the main responsibility lied at each level of governance, by level of education

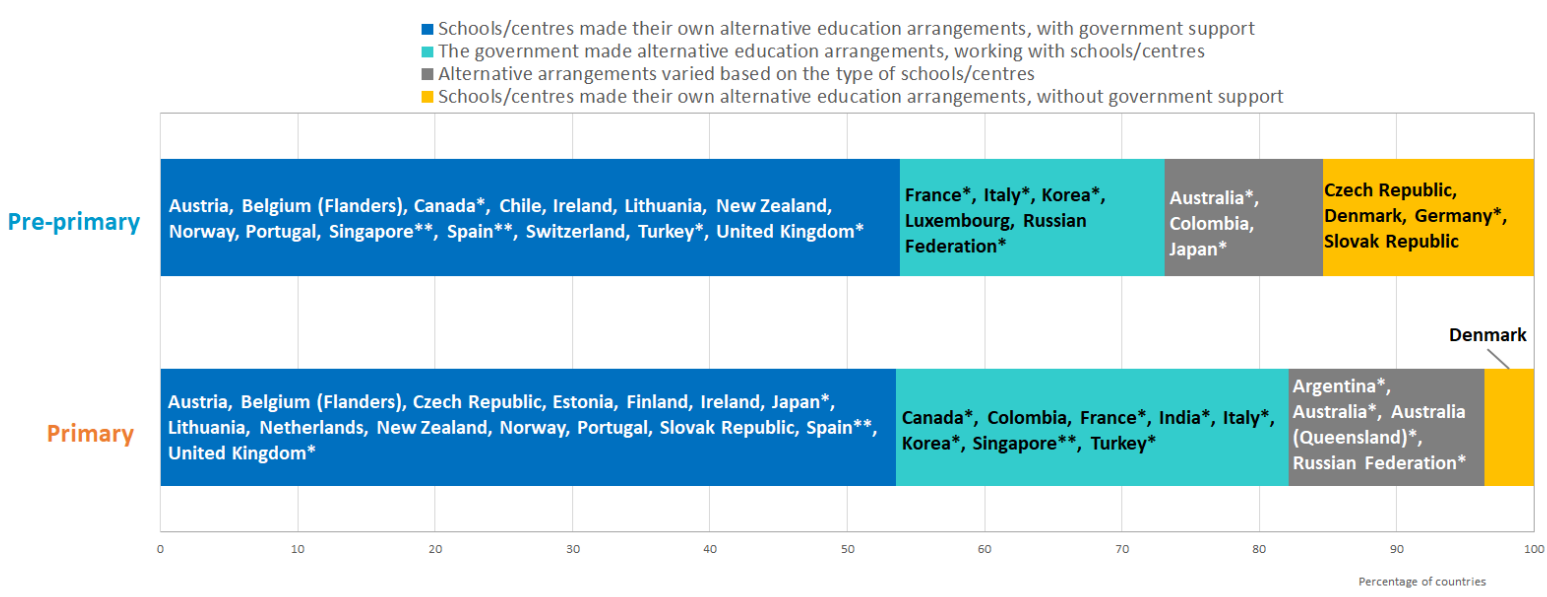

* G20 member countries are indicated with an asterisk.

** G20 guest countries are indicated with a double asterisk.

Note: Only countries with displayed response categories are included in the analysis (i.e. "not applicable" excluded from the percentages).

Source: OECD Survey on Distance Education for Young Children in 2020. 
Responses to the survey also provide an indication of the commitment of $G 20$ and OECD countries to maintaining continuity of education for young children in 2020. This is illustrated by the requirements for teachers to continue working during school/centre closures with the goal to maintain continuity of education through alternative means. Such requirement existed for primary teachers in $86 \%$ of the participant countries, and for pre-primary teachers in $70 \%$ of the countries (Figure 3.2).

\section{Figure 3.2. Work requirements for teachers during school/centre closures in 2020}

Percentage of countries where teachers were required to work during school/centre closures, by level of education

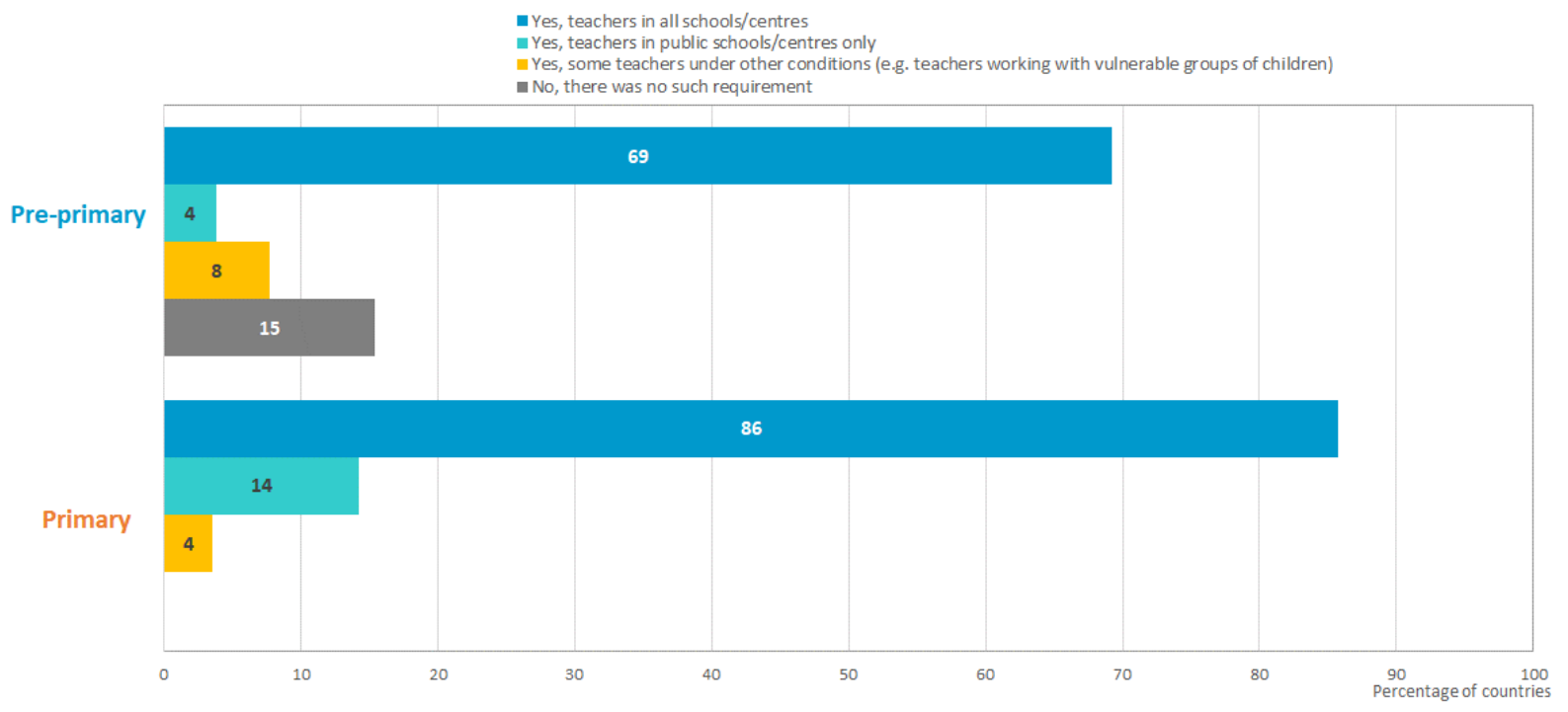

Note: "Teacher" refers to a person whose professional activity involves planning, organising and conducting classroom/playgroup/group activities whereby children's knowledge, skills and attitudes develop as stipulated by educational programmes/guidelines. Source: OECD Survey on Distance Education for Young Children in 2020.

Results from the survey suggest, however, less frequent requirements for school/centre leaders or teachers to maintain communication and contact with young children's parents and caregivers during periods of closure. At the primary level of education, this role was required from leaders and teachers in about $75 \%$ of countries, whereas at the pre-primary level it was expected in $62 \%$ of countries only. This somewhat weaker commitment to maintaining communication with families may reflect that traditionally formal communications tended to be problem-focused (e.g. reporting of incidents), rather than be conceived as a channel for broader types of exchanges. Preserving responsive contact points in schools/centres can be of critical importance for young children, not only for learning purposes but also and more importantly on the socio-emotional well-being dimension (see Table A. 2 in the Annex).

\section{Using digital technology to maintain continuity of education}

In 2020, countries organised distance education to maintain the continuity of education for young children. The survey defines distance education as digital or broadcast technologies that delivers instruction to children who are separated from the instructor and to support regular and substantive interaction between the children and the instructor in real-time (synchronously) or not (asynchronously). In what follows, the next paragraphs describe how countries used digital technologies to manage "full" or "partial" school/centre closures in 2020. 
Figure 3.3 shows countries' perceptions on the suitability of digital technologies to maintain continuity of education during school/centre closures as a result of the COVID-19 pandemic. A large majority of participating countries (79\%) considered digital technologies as an appropriate tool to maintain continuity of education for young children "to a great" or "to moderate extent", both at the pre-primary and primary levels of education. This is however compatible with an equally widely shared perception that digital technologies had to be adopted out of necessity and lack of alternatives for providing distance education during school/centre closures.

At both levels of education, there is a large variation across countries in the importance that different types of digital technologies and content have played in maintaining education of young children during school/centre closures in 2020. At both levels of education, learning materials shared digitally with parents/caregivers to be used without exposing children to screens were reported to have had a "major importance" by about $60 \%$ of participating countries, including for instance by Australia and Korea. A similar share of countries (56\%) countries reported that digital technologies involving direct exposure of children to screens with interactive functions were key in early years of primary education settings (e.g. Australia, Australia [Queensland], Japan and Korea). By contrast, only $17 \%$ of countries had the same response for pre-primary classrooms (e.g. Korea) (Figure 3.4).

A smaller, yet significant gap between the two education levels relates to the role played by digital technologies that enable real-time classes or activities between teachers and children. These technologies were reported as having been "very important" at the pre-primary level in $25 \%$ of participating countries, including Australia, Japan and Korea, whereas twice the share of countries (52\%) report that level of importance at the primary level, including countries such as Canada, India, Russian Federation or Turkey. Between $30 \%$ and $40 \%$ of countries indicated that video call/meetings between teachers and parents/caregivers to support children's learning and digital material involving direct exposure of children to screens without interactive functions were of "major importance" at both levels of education. 
Figure 3.3. Use of digital technologies in response to the COVID-19 pandemic

Percentage of countries reporting different levels of intensity/exposure, by level of education

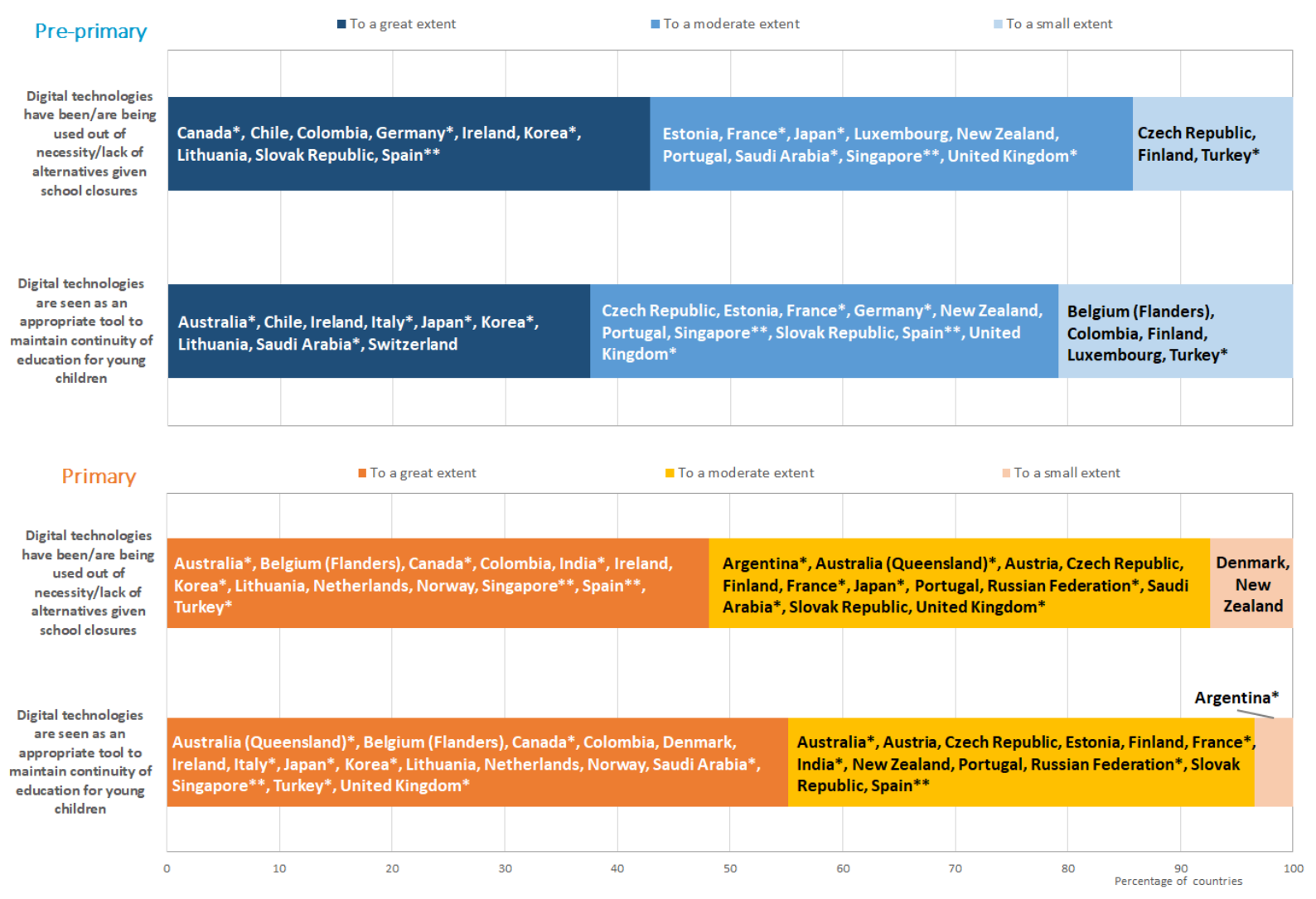

* G20 member countries are indicated with an asterisk.

** G20 guest countries are indicated with a double asterisk.

Note: Only countries with displayed response categories are included in the analysis (i.e. "not at all", "not known" and "not applicable" excluded from the percentages).

Source: OECD Survey on Distance Education for Young Children in 2020. 
Figure 3.4. Importance of different types of digital technologies in maintaining continuity of education for young children in 2020

Percentage of countries reporting different levels of importance, by level of education

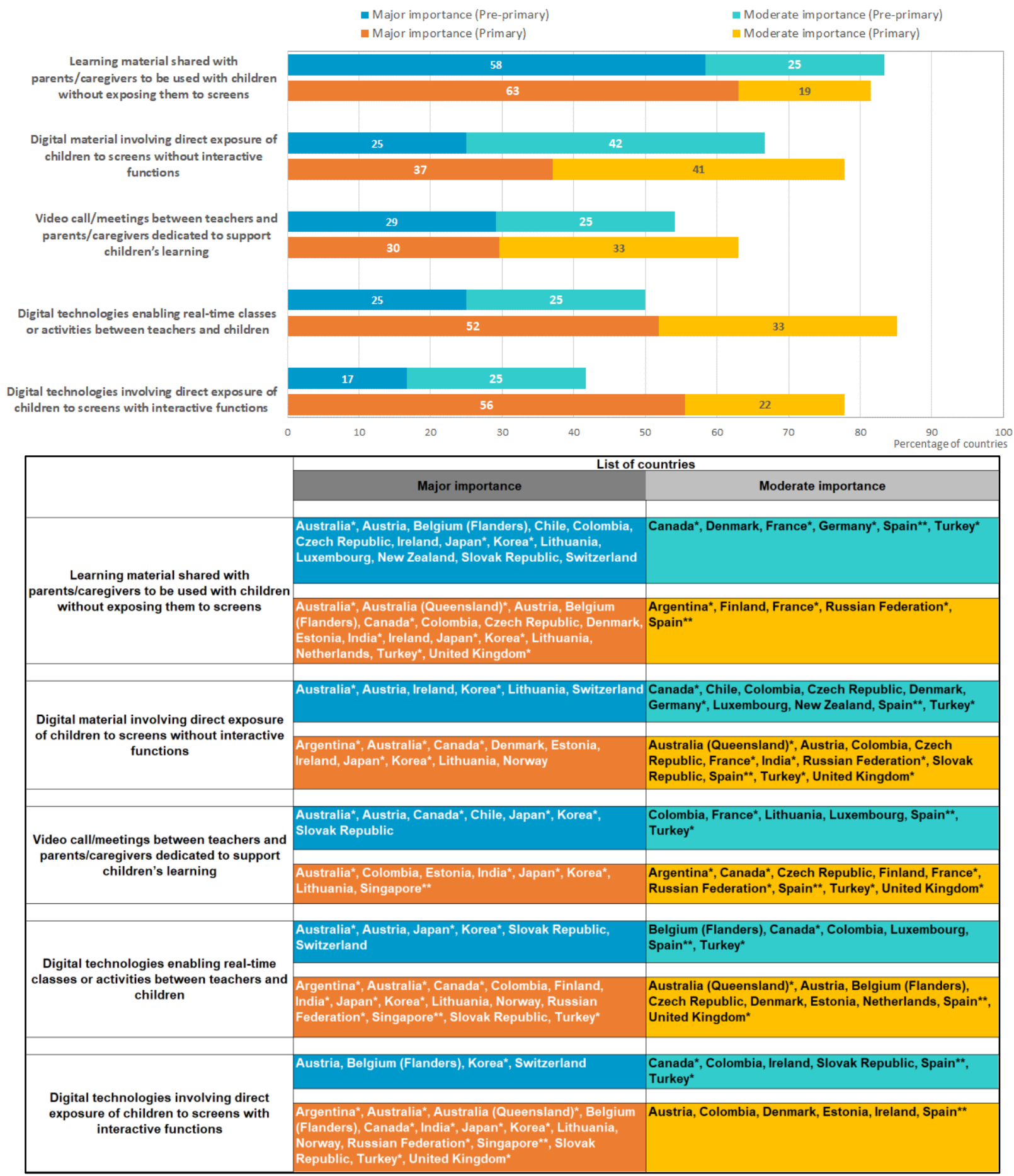

* G20 member countries are indicated with an asterisk.

** G20 guest countries are indicated with a double asterisk.

Note: Items are sorted in descending order by the sum of response categories "major" and "moderate" importance in pre-primary education. Source: OECD Survey on Distance Education for Young Children in 2020. 
Concerning the type of digital technologies used to maintain the continuity of education for young children, open source distance education platforms and apps were used "to a great extent" in pre-primary education by $43 \%$ of participating countries. This is followed by distance education and apps created by the Ministry of Education or education authorities (31\% of countries). In addition, $65 \%$ of countries reported that distance education and apps created by the Ministry of Education or education authorities were used "to a great extent" in the early years of primary education, twice the percentage of countries where open source and commercial education platforms and apps had such importance in efforts to maintain continuity of education for young children (Figure 3.5).

Figure 3.5. Type of digital technologies used to maintain continuity of education for young children

Percentage of countries reporting that the following technologies were used in 2020, by level of education

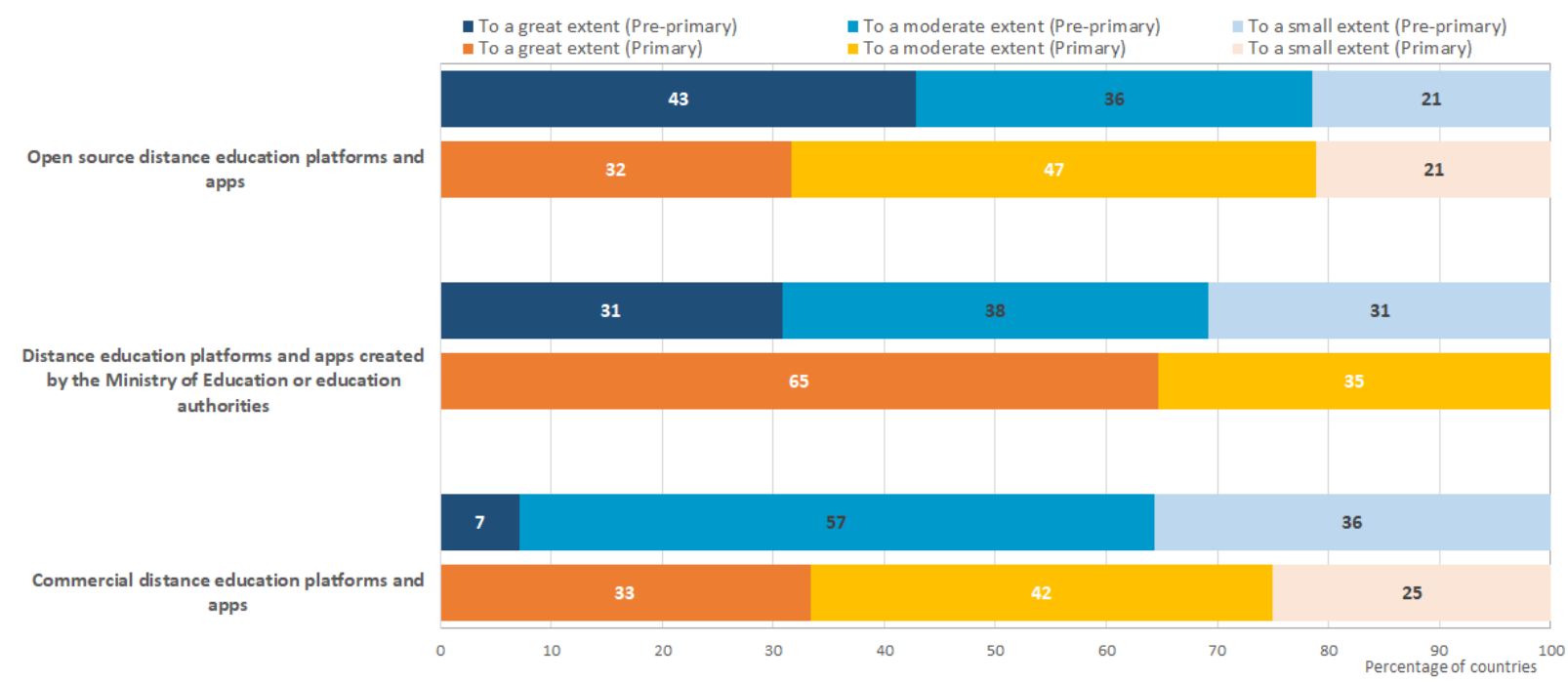

* $G 20$ countries are indicated with an asterisk.

** G20 guest countries are marked with a double asterisk.

Notes: Only countries with displayed response categories are included in the analysis (i.e. "not at all", "not known" and "not applicable" excluded from the percentages). Items are sorted in descending order by the response category "to a great extent" in pre-primary education. Source: OECD Survey on Distance Education for Young Children in 2020.

The survey collected also information on the estimated amount of time that children would spend with digital tools as part of the activities proposed in distance education arrangements. Results indicate that children in the early years of primary education were more exposed to digital technologies than children in pre-primary education. Only one out of five countries with available data (e.g. the United Kingdom) reported that children in pre-primary classrooms were expected to spend more than one hour per day in real-time classes during the first period of school/centre closures in 2020. Conversely, around half of the countries (e.g. Argentina, India, Korea and Turkey) reported the same expectation in the early years of primary education (Figure 3.6).

A similar pattern is observed about the expected daily exposure to screens as part of interactive activities. In around three out of four countries with available data (e.g. Canada, France, Korea and Turkey), children in pre-primary education were expected to spend no more than one hour per day in front of screens on assigned interactive activities. In early years of primary education, however, around three out of four participating countries (e.g. Estonia, Korea, Australia [Queensland]) reported expectations of between one and four hours per day of screen time on interactive activities. 
The gap between education levels is somewhat smaller with respect to the time that parents/caregivers' were expected to spend communicating with school staff using digital tools. In $78 \%$ of the countries (e.g. Australia and Korea), the estimated time that parents of children in pre-primary education would spend communicating with teachers using digital tools was one hour or less per day. The same holds for communication through digital channels in the early years of primary education in $54 \%$ of the participating countries and jurisdictions (e.g. Australia [Queensland], India, Korea and Turkey).

Figure 3.6. Time spent using digital tools as part of distance education activities in 2020

Estimated amount of time (number of hours per day) that children and parents spent using digital tools in the following activities during school/centre closures in 2020 , by level of education

\section{Pre-primary}

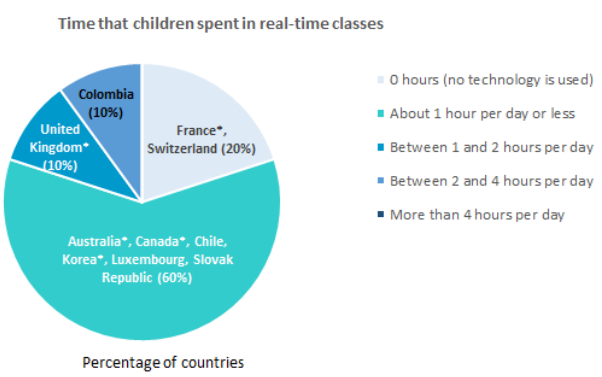

Time that children are exposed to screens on assigned interactive activities

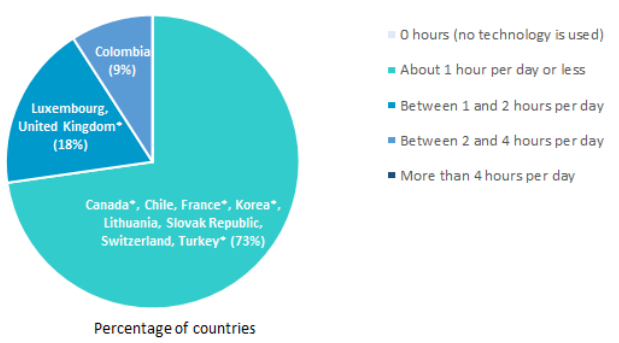

Time that parents/caregivers' spent communicating with school staff using digital
tools

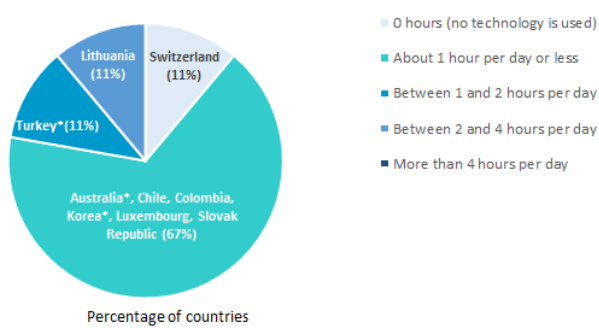

Primary
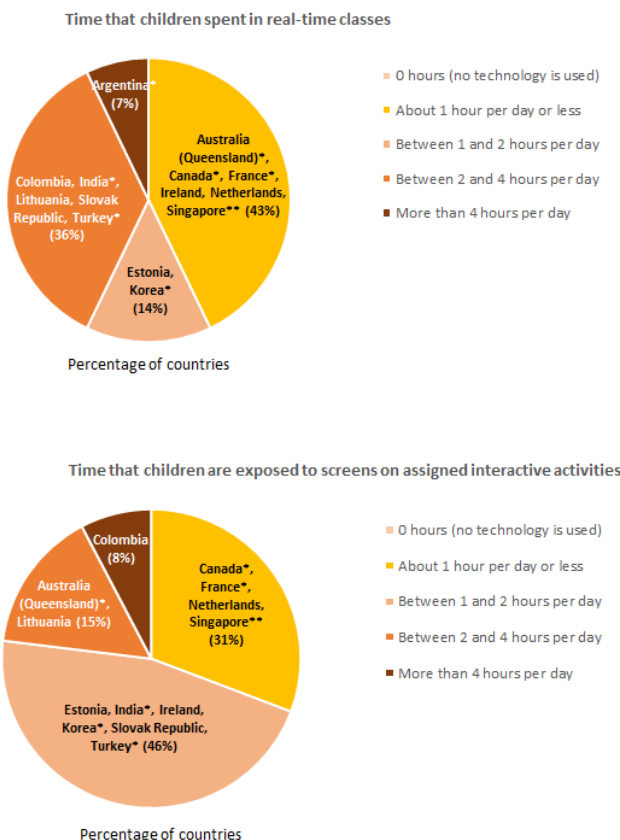

Time that parents/caregivers' spent communicating with school staff using digital tools

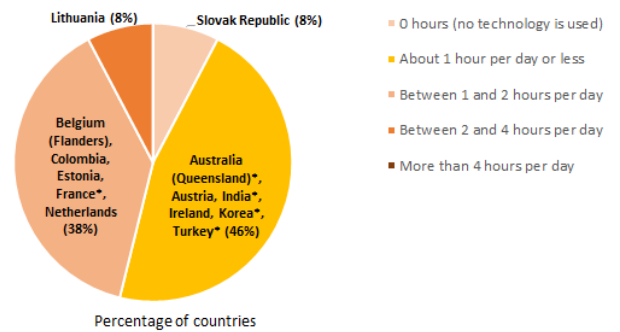

* G20 countries are indicated with an asterisk.

** G20 guest countries are marked with a double asterisk.

Note: Only countries with displayed response categories are included in the analysis (i.e. "not known" and "not applicable" excluded from the percentages).

Source: OECD Survey on Distance Education for Young Children in 2020 


\section{Prior approaches and use of real-time and interactive solutions in 2020}

An analysis about the relationship between the extent of use of digital technologies in early education prior to and in response to the COVID-19 pandemic shows that countries where real-time and interactive digital solutions were reported to have a major importance in responding to the pandemic were generally countries where early education teachers were already expected to use digital technologies in their work with children to a "moderate" or "great" extent prior to 2020. By contrast, a weaker reliance on these types of solutions tends to be reported by countries where expectations that teachers would integrate technology in their work with children were lower (Figure 3.7). The association is more visible at the pre-primary level of education, where there is more variation across countries in the extent of use of these technologies in 2020. At the primary level, however, even countries where expectations of technology use were low prior to the pandemic relied more heavily on interactive solutions in 2020.

Countries reporting that both prior expectations and use in 2020 were low at the pre-primary level include Australia, Chile, Czech Republic and Luxembourg, whereas Belgium (Flanders), Korea and Switzerland reported high use and moderate or expectations for pre-primary education. Japan reported high expectations for technology use by teachers at both levels, but low use of interactive solutions in pre-primary and high use in primary in 2020. Generally, though, at the primary level of education countries tend to cluster on the right-hand side of the panel, indicating greater use of interactive digital solutions in 2020, without a clear association with prior expectations.

Figure 3.7. Country profiles for the association between prior expectations for the use of technology in early education and importance of interactive solutions in 2020

Expectations on teachers' use of digital technologies prior to the pandemic and importance of real-time and interactive solutions in 2020, by level of education

\section{Pre-primary}

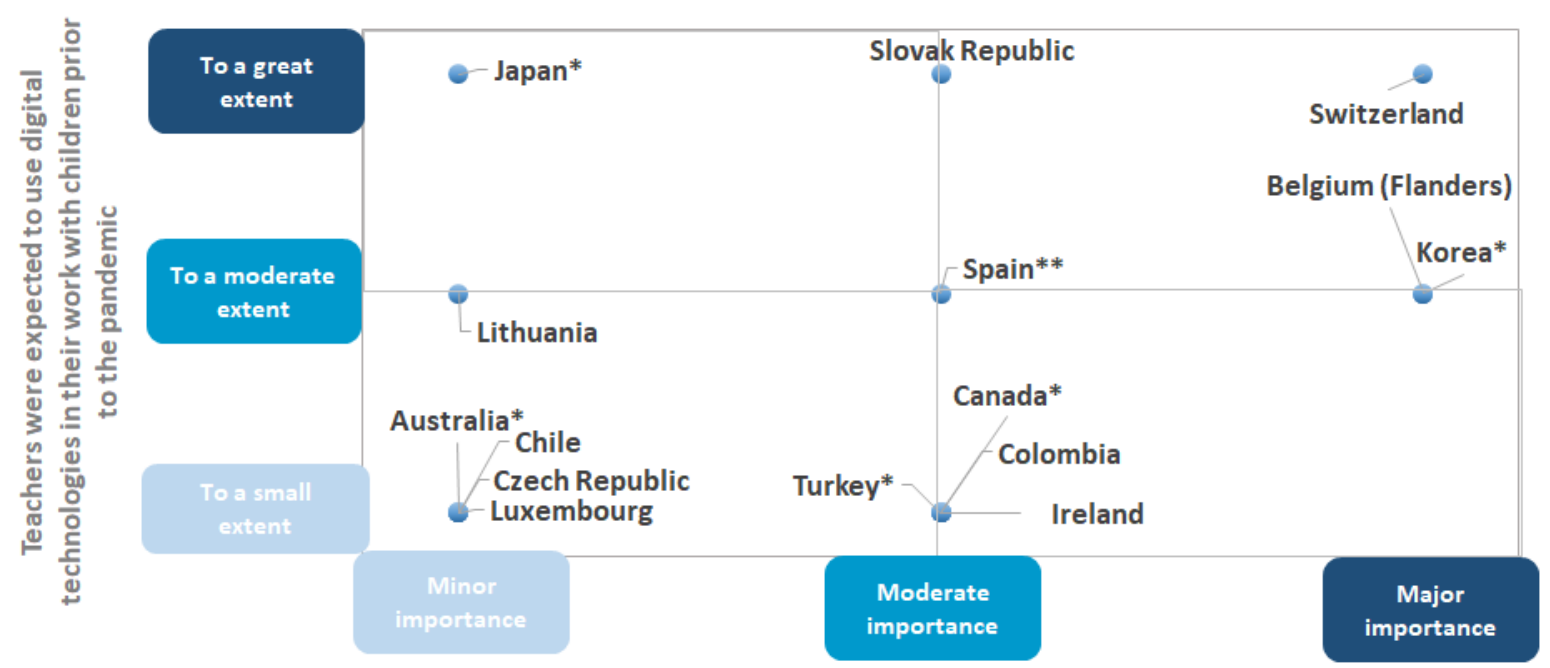

Digital technologies involving direct exposure of children to screens with interactive functions 


\section{Primary}

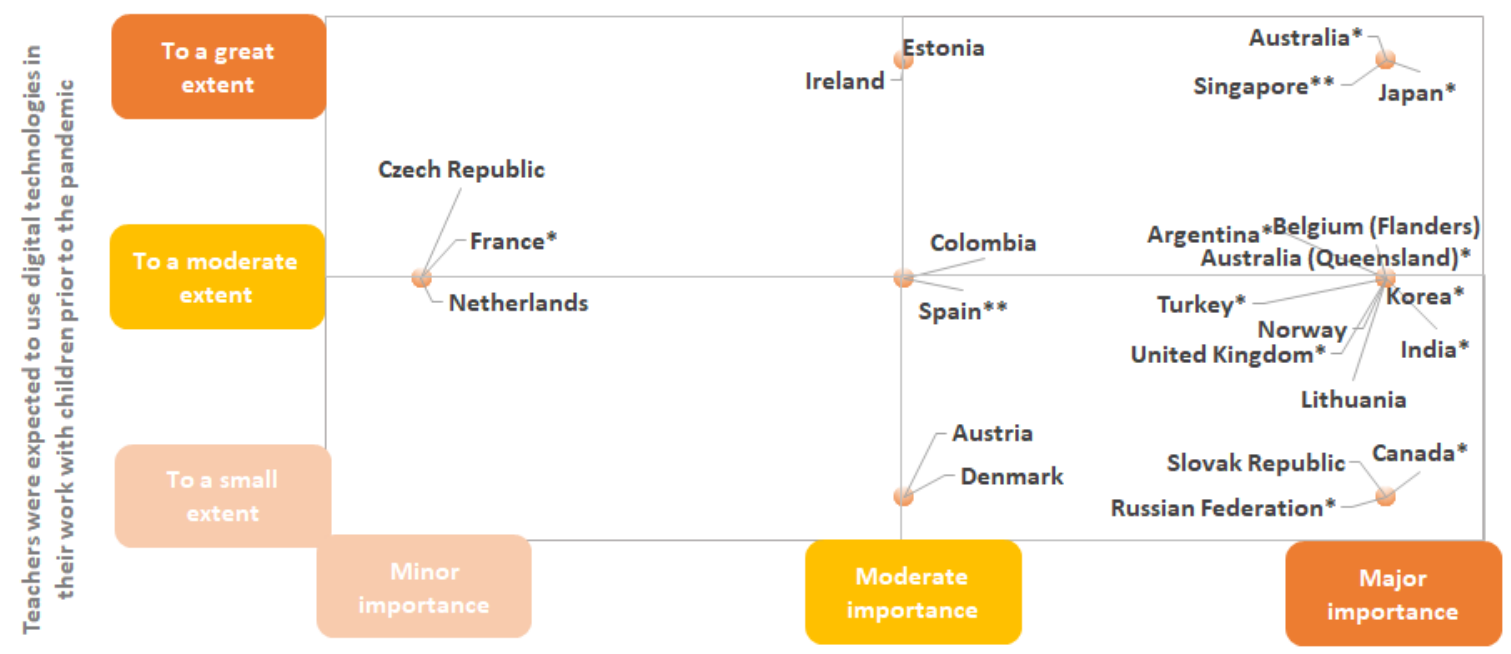

Digital technologies involving direct exposure of children to screens with interactive functions

* $\mathrm{G} 20$ countries are indicated with an asterisk.

** $G 20$ guest countries are marked with a double asterisk.

Note: Only countries with comparable data at both levels of education are shown.

Source: OECD Survey on Distance Education for Young Children in 2020.

\section{Prioritisation of curriculum areas in distance education}

While providing distance education to maintain continuity of education for young children during school/centre closures in 2020, less than half of the countries participating in the survey gave priority to specific curricular areas or skills (see Table A. 1 in Annex).

At the pre-primary level of education, the following areas became a strong priority in 10 countries, including Australia, Canada, Italy and Spain: facilitating children's language and literacy development; encouraging children to maintain contact with teaching staff; facilitating children's numeracy development; facilitating children's socio-emotional development or encouraging children's play. Children's sense of belonging to a group became a stronger priority in four countries and a lower priority in another four (Figure 3.8).

In the early years of primary education, 12 countries reported that some skills became a stronger priority during school/centre closures in 2020. Core development areas/academic subjects, such as reading, writing and literature mathematics and information and communication technologies (ICT) became a stronger priority in eight of the countries with valid responses. In India and Italy, information and communication technologies (ICT) became a stronger priority over other development skills, while in Canada, reading and mathematics did so (Figure 3.9). These results are consistent with the adjustments to curriculum reported in other international data collections exploring the impact of the pandemic on school education (OECD, $\left.2021_{[6]}\right)$. 
Figure 3.8. Prioritisation of pre-primary curriculum areas during distance education in 2020

\begin{tabular}{|c|c|c|c|c|c|c|c|c|c|}
\hline & \multicolumn{9}{|c|}{ Areas/skills } \\
\hline & $\begin{array}{c}\text { Facilitating } \\
\text { children's } \\
\text { language and } \\
\text { literacy } \\
\text { development }\end{array}$ & $\begin{array}{l}\text { Facilitating } \\
\text { children's } \\
\text { numeracy } \\
\text { development }\end{array}$ & $\begin{array}{l}\text { Facilitating } \\
\text { children's } \\
\text { physical } \\
\text { development }\end{array}$ & \begin{tabular}{|c|} 
Facilitating \\
children' socio- \\
emotional \\
development
\end{tabular} & $\begin{array}{c}\text { Facilitating } \\
\text { children's } \\
\text { creativity and } \\
\text { problem } \\
\text { solving skills }\end{array}$ & $\begin{array}{c}\text { Facilitating } \\
\text { children's } \\
\text { artistic } \\
\text { expression or } \\
\text { learning in the } \\
\text { arts }\end{array}$ & $\begin{array}{l}\text { Encouraging } \\
\text { children's play }\end{array}$ & $\begin{array}{c}\text { Encouraging } \\
\text { or maintaining } \\
\text { children's } \\
\text { sense of } \\
\text { belonging to a } \\
\text { group }\end{array}$ & $\begin{array}{l}\text { Encouraging } \\
\text { children to } \\
\text { maintain } \\
\text { contact with } \\
\text { teaching staff }\end{array}$ \\
\hline \multicolumn{10}{|l|}{ Argentina* $^{*}$} \\
\hline \multicolumn{10}{|l|}{ Australia ${ }^{*}$} \\
\hline \multicolumn{10}{|l|}{ Australia (Queensland)* } \\
\hline \multicolumn{10}{|l|}{ Austria } \\
\hline \multirow{2}{*}{\multicolumn{10}{|c|}{\begin{tabular}{|l|} 
Belgium (Flanders) \\
Canada $^{*}$
\end{tabular}}} \\
\hline & & & & & & & & & \\
\hline \multicolumn{10}{|l|}{ Chile } \\
\hline \multicolumn{10}{|l|}{ Colombia } \\
\hline \multirow{2}{*}{\multicolumn{10}{|c|}{\begin{tabular}{|l} 
Czech Republic \\
Denmark
\end{tabular}}} \\
\hline & & & & & & & & & \\
\hline \multicolumn{10}{|l|}{$\begin{array}{l}\text { Uenmark } \\
\text { Estonia }\end{array}$} \\
\hline \multicolumn{10}{|l|}{ Finland } \\
\hline \multicolumn{10}{|l|}{ France $^{*}$} \\
\hline \multirow{2}{*}{\multicolumn{10}{|c|}{\begin{tabular}{|l} 
Germany* \\
Iceland
\end{tabular}}} \\
\hline & & & & & & & & & \\
\hline \multicolumn{10}{|l|}{ India ${ }^{*}$} \\
\hline \multirow{2}{*}{\multicolumn{10}{|c|}{ Ireland }} \\
\hline \multirow{2}{*}{\multicolumn{10}{|c|}{\begin{tabular}{|l|} 
Italy* \\
$J a p a n^{*}$
\end{tabular}}} \\
\hline & & & & & & & & & \\
\hline \multirow{2}{*}{\multicolumn{10}{|c|}{\begin{tabular}{|l|} 
Korea $^{*}$ \\
Lithuania
\end{tabular}}} \\
\hline & & & & & & & & & \\
\hline \multicolumn{10}{|l|}{ Luxembourg } \\
\hline \multicolumn{10}{|l|}{ Netherlands } \\
\hline \multirow{2}{*}{\multicolumn{10}{|c|}{\begin{tabular}{|l|} 
New Zealand \\
Norway
\end{tabular}}} \\
\hline \multirow{2}{*}{\multicolumn{10}{|c|}{\begin{tabular}{|l|} 
Norway \\
Portugal
\end{tabular}}} \\
\hline & & & & & & & & & \\
\hline \multicolumn{10}{|l|}{ Russian Federation* } \\
\hline \multicolumn{10}{|l|}{ Saudi Arabia* } \\
\hline Singapore ${ }^{\star \star \star}$ & & & & & & & & & \\
\hline Slovak Republic & & & & & & & & & \\
\hline Spain** & & & & & & & & & \\
\hline Switzerland & & & & & & & & & \\
\hline Turkey* & & & & & & & & & \\
\hline United Kingdom* ${ }^{*}$ & & & & & & & & & \\
\hline Countries with no prioritisation & 11 & 11 & 11 & 11 & 11 & 11 & 11 & 11 & 11 \\
\hline Countries with lower priority & 0 & 0 & 3 & 1 & 0 & 1 & 1 & 4 & 0 \\
\hline $\begin{array}{l}\text { Countries with same priority as } \\
\text { before }\end{array}$ & 3 & 4 & 4 & 3 & 7 & 5 & 3 & 1 & 3 \\
\hline $\begin{array}{l}\text { Countries with stronger } \\
\text { priority }\end{array}$ & 7 & 6 & 2 & 6 & 2 & 3 & 6 & 4 & 7 \\
\hline
\end{tabular}

* $G 20$ countries are indicated with an asterisk.

** G20 guest countries are marked with a double asterisk.

Note: The question refers to the whole of 2020.

Source: OECD Survey on Distance Education for Young Children in 2020. 
Figure 3.9. Prioritisation of primary curriculum areas during distance education in 2020

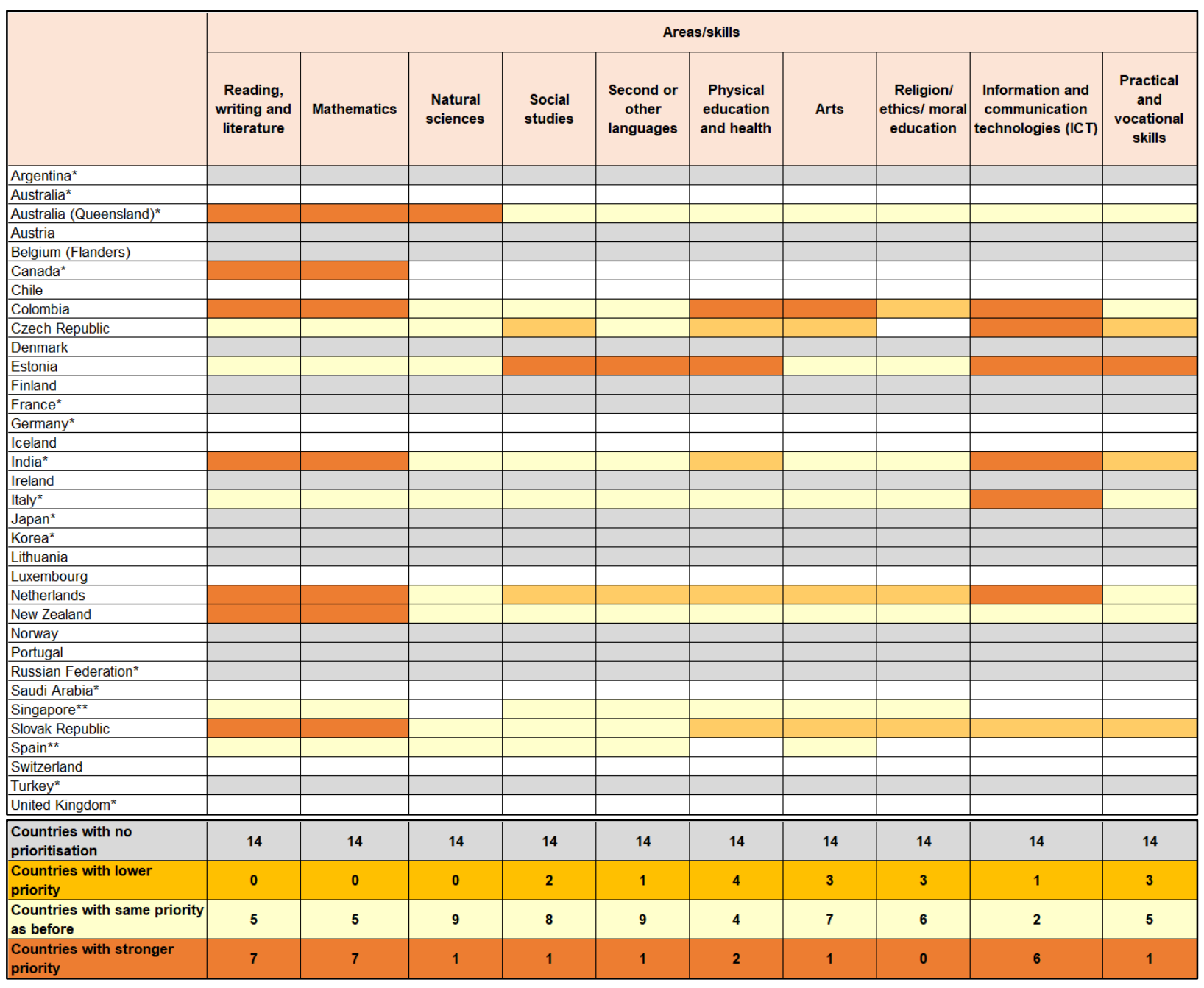

* G20 countries are indicated with an asterisk.

* * G20 guest countries are marked with a double asterisk.

Note: The question refers to the whole of 2020

Source: OECD Survey on Distance Education for Young Children in 2020.

\section{Using digital technologies to engage with parents and families}

Communicating/engaging parents and families are key for providing parental support for learning attitudes as children demonstrate more positive attitudes and dispositions towards learning when they benefit from more parental emotional support $\left(O E C D, 2020_{[13]}\right)$. On average across OECD countries participating in OECD's Teaching and Learning International Survey (TALIS), prior to the pandemic, teachers reported having spent an average of 1.4 hours on communication and co-operation with parents or guardians during the most recent complete calendar week. Moreover, 9\% of teachers on average reported a high level of need for professional development in teacher-parent/guardian co-operation (OECD, 2019[14]].

Survey results show that in most participating countries the use of digital technologies for purposes other than direct education delivery varied notably between the pre-primary and primary levels of education (Figure 3.10). During the first period of school/centre closure in 2020, $64 \%$ of countries reported that they used digital 
technologies for communication between school/centre leaders and teachers "to a great extent" in pre-primary education settings. This is followed by uses for supporting parents/caregivers in their role as educators (43\%); communication with parents/caregivers to identify child maltreatment $(43 \%)$; communication with parent/caregivers about children's emotional well-being (35\%); and communicating with parents/caregivers about children's nutrition and health $(24 \%)$. In the early years of primary education, a larger share of countries reported that digital technologies had a major role for maintaining the relationship between parents and teachers. $77 \%$ of countries used digital technologies for communication between school/centre leaders and teachers "to a great extent" in the early years of primary education. This is followed by supporting parents/caregivers in their role as educators (59\%); communicating with parents/caregivers about children's nutrition and health (57\%); communication with parent/caregivers about children's emotional well-being (41\%); and communication with parents/caregivers to identify child maltreatment (38\%).

Figure 3.11 shows differences countries' approaches in more detail. For example, extensive use of digital technologies to support parents/caregivers in their role as educators and to communicate with them about children's emotional well-being was reported at both levels of education by Italy, Korea, and Portugal.

\section{Figure 3.10. Extent of use of digital technologies for purposes other than direct education} delivery

Percentage of countries reporting different intensity of use, by level of education

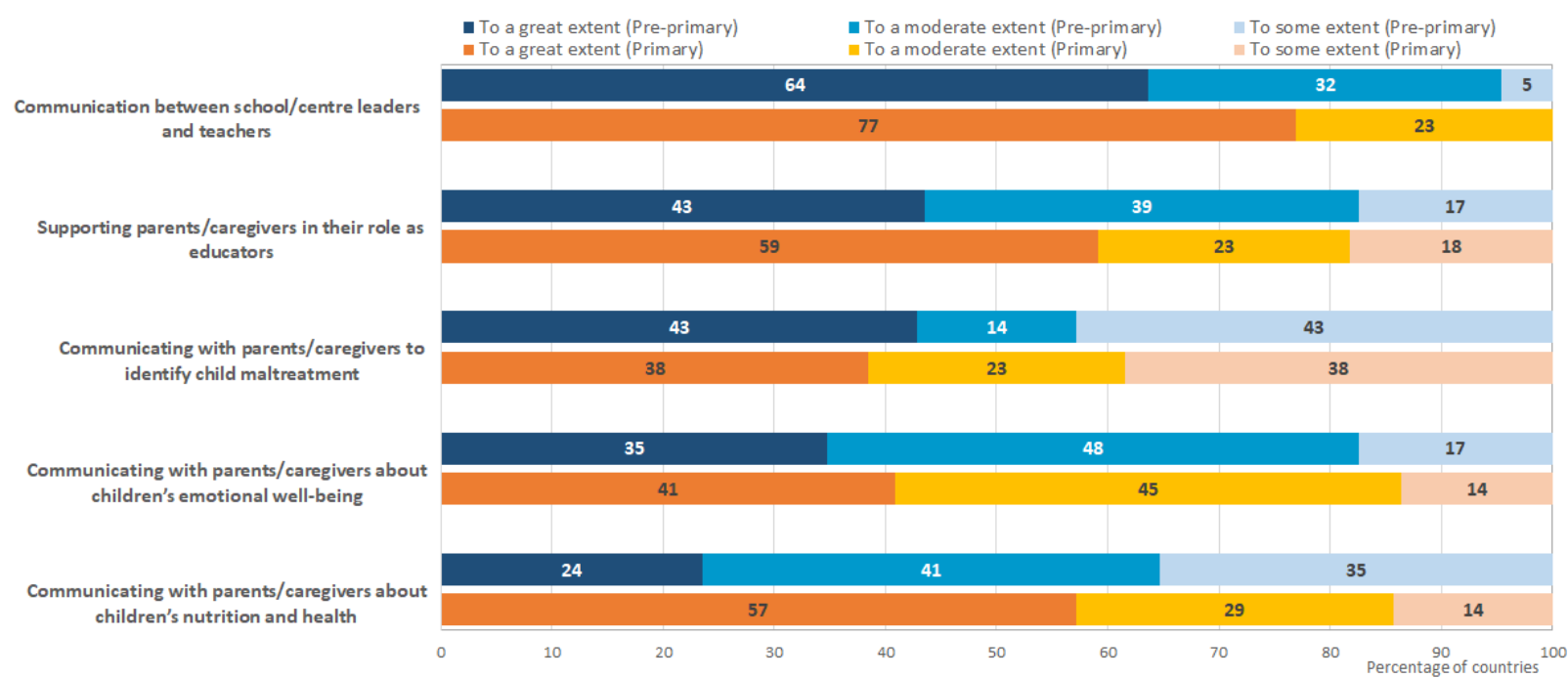

* $G 20$ countries are indicated with an asterisk.

** G20 guest countries are marked with a double asterisk.

Notes: Only countries with displayed response categories are included in the analysis (i.e. "not at all", "not known" and "not applicable" excluded from the percentages). Items are sorted in descending order by the response category "to a great extent" in pre-primary education. Source: OECD Survey on Distance Education for Young Children in 2020. 
Figure 3.11. Country profiles in the use of digital technologies in 2020 for purposes other than direct education delivery

Intensity of use, by level of education

Supporting parents/caregivers in their role as educators

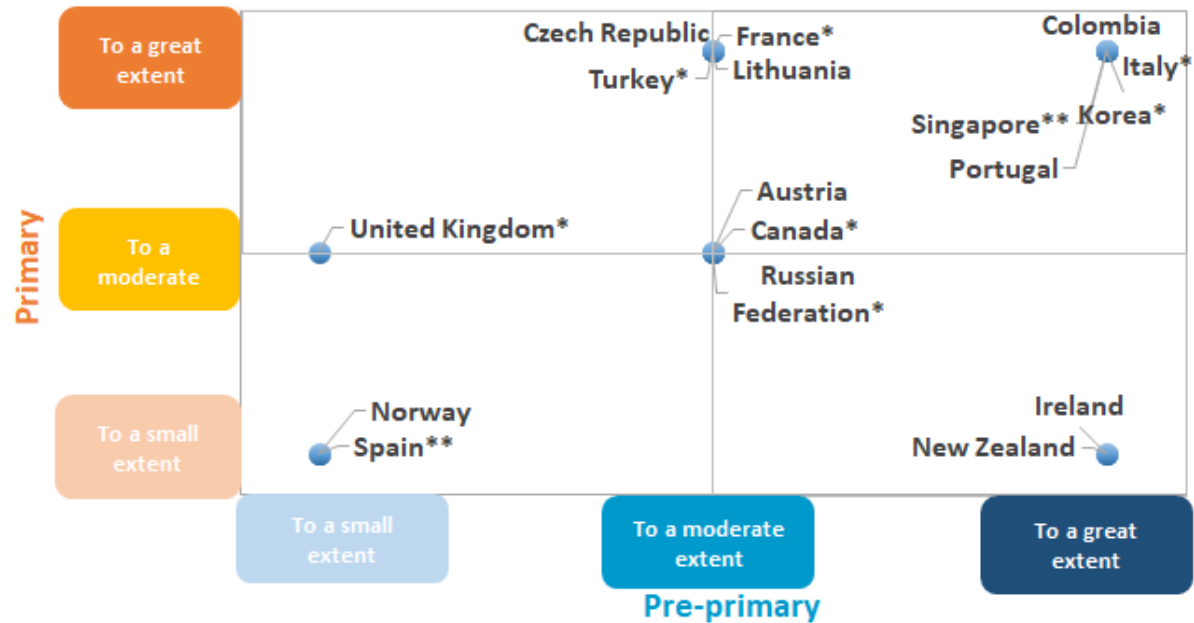

Communicating with parents/caregivers about children's emotional well-being

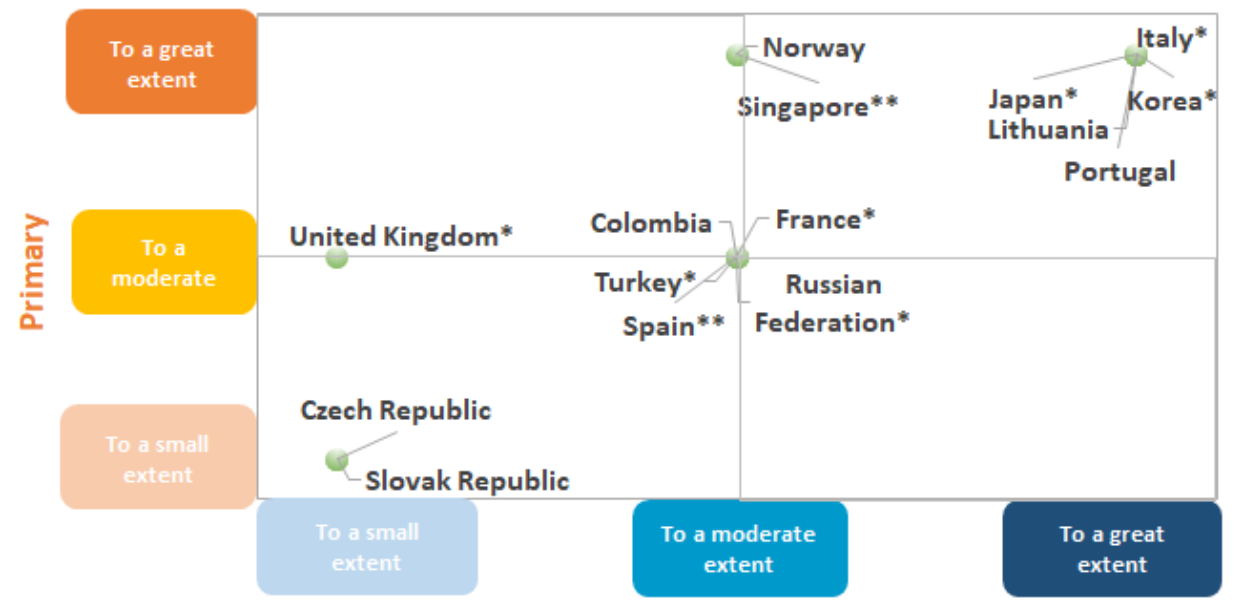

* $G 20$ countries are indicated with an asterisk.

** G20 guest countries are marked with a double asterisk.

Note: Only countries with comparable data at both levels of education are shown.

Source: OECD Survey on Distance Education for Young Children in 2020.

\section{Use of broadcast technologies}

Beyond digital technologies, a majority of countries mobilised other resources to keep young children engaged in education activities during the first period of school/centre closure in 2020. Around 19 participating countries responded that broadcast technologies (e.g. television, radio) were used as a complement to digital technologies to maintain continuity of education for young children from age 3 to 6 (e.g. Australia, Canada, France and Germany) and from age 7 to 8 (e.g. Argentina, Australia, France, India, Italy and the United Kingdom). 
Around six countries/jurisdiction did not use at all broadcast technologies in pre-primary (e.g. Japan, Russian Federation and Singapore) or in early years of primary education settings (e.g. Russian Federation and Singapore).

Countries adopted a variety of approaches to generate the content offered to young children through broadcast technologies in 2020 (see Box 3.1 and Table A.3 in the Annex). In Canada, Italy, Spain and Turkey, the Ministry of Education or sub-national education authorities were mainly responsible for the content offered through these programmes in pre-primary levels of education, whereas in Germany the responsibility rested with the (mainly public or publicly controlled) TV and radio channels. In France, content creation was largely outsourced to a third party, with input from teachers, and was validated by the General Inspection for Education. Australia, Italy, Korea and the United Kingdom used different sources at each of the two levels of education.

\section{Box 3.1. Examples from G20 member countries: Building on broadcast technologies for education}

Australia, for example, has a long tradition of "School of the Air" programmes historically using radio for the education of children in remote areas. These programmes continued to operate during COVID-19 crisis providing services to children and families mostly in rural and very remote locations.

In Italy, for children in primary schools, RAI (Radiotelevisione italiana, the national public broadcasting company of Italy) and the Ministry of Education shared the responsibility for the content of programmes.

In Korea, on 23 March 2020, EBS (Educational Broadcasting System, an educational public broadcaster and radio network covering the entire South Korean territory) created different channels to support the specific needs of students in different school grades in cooperation with metropolitan and provincial offices of education, schools, and teachers. For first and second year students of primary schools, who may experience difficulty in participating in online classes, EBS TV classes were broadcasted, while for the rest of the relatively older students, EBS Live Class was offered online to assist their real-time education. In addition, EBS produced and broadcasted educational TV programmes for younger children by cooperating with provincial offices of education.

In Spain, the Ministry of Education and the state-owned national television broadcaster (TVE) created the programme "Aprendemos en casa" to support children in primary education with no digital connectivity or equipment at home.

Source: OECD Survey on Distance Education for Young Children in 2020.

Around $60 \%$ of countries that used broadcast technologies for remote learning attributed "moderate" or "major importance" to new TV programmes especially designed to support children's education during school/centre closures at both levels of education. A similar share (58\%) of countries reported that existing TV programmes were important in pre-primary education, and a larger share (80\%) of countries reported the same strategy for children in the early years of primary education. Australia, India, Italy, Germany, Korea and Japan are among the countries that emphasised the importance of using both new and existing TV programmes to support children's education during school/centre closures (Figure 3.12). Radio programmes were less extensively used across countries to maintain continuity of education for young children. Around $30 \%$ of countries, including Australia, Germany, India, and Korea reported that the use of existing radio programmes were at least moderately important at both levels of education. 
Figure 3.12. Importance of broadcast technologies for maintaining continuity of education for young children in 2020

Percentage of countries reporting each level of importance, by level of education

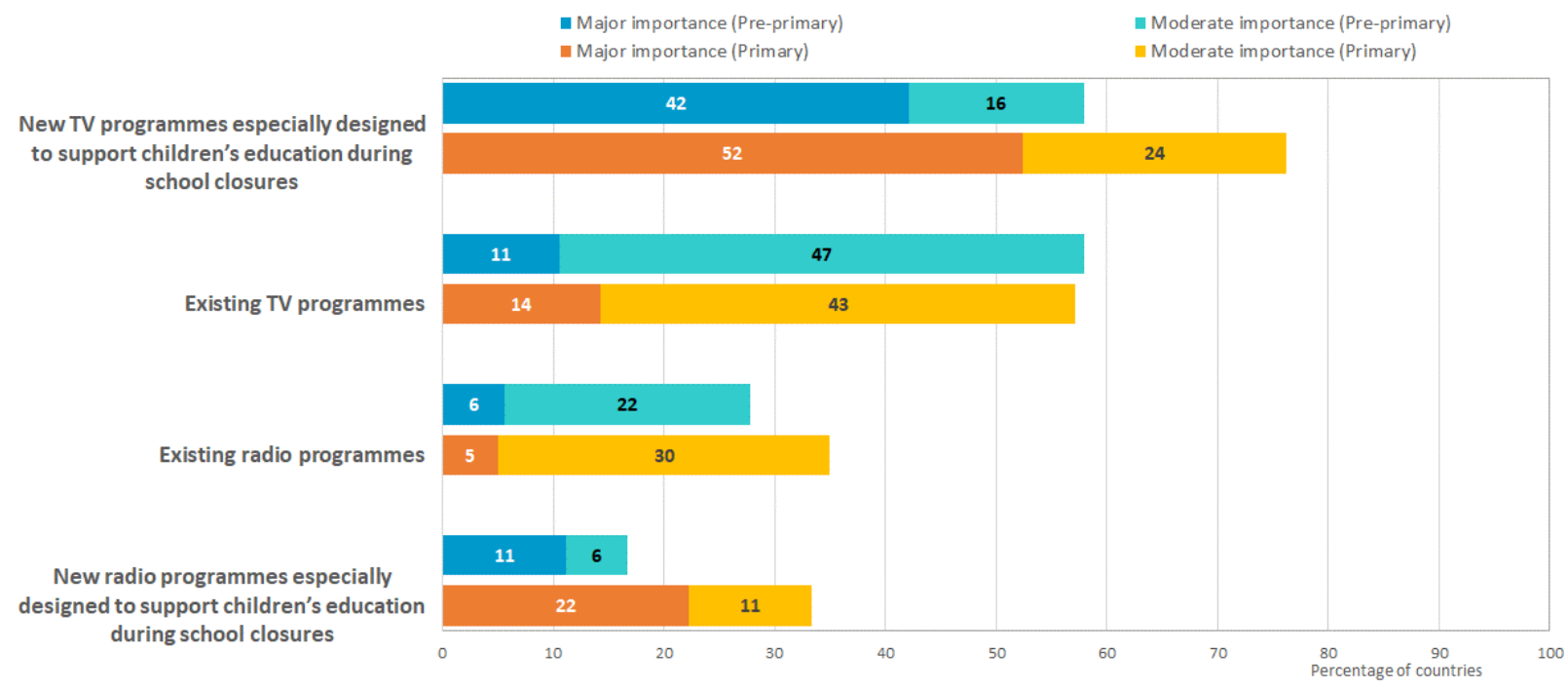

\begin{tabular}{|c|c|c|}
\hline & \multicolumn{2}{|c|}{ List of countries } \\
\hline & Major importance & Moderate importance \\
\hline \multirow{2}{*}{$\begin{array}{l}\text { New TV programmes especially designed to } \\
\text { support children's education during school } \\
\text { closures }\end{array}$} & $\begin{array}{l}\text { Austria, Chile, Colombia, Ireland, Korea }{ }^{\star} \text { New } \\
\text { Zealand, Switzerland, Turkey* }\end{array}$ & Belgium (Flanders), Lithuania \\
\hline & 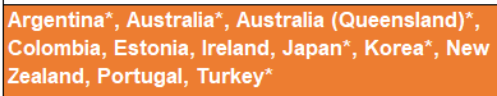 & $\begin{array}{l}\text { Czech Republic, France }{ }^{\star} \text {, India }{ }^{*}, \text { Italy }^{*} \text {, United } \\
\text { Kingdom* }\end{array}$ \\
\hline \multirow[b]{2}{*}{ Existing $\mathrm{TV}$ programmes } & Portugal, Slovak Republic & 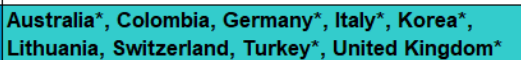 \\
\hline & \begin{tabular}{|l} 
Australia*, Colombia, Japan* \\
${ }^{*}$
\end{tabular} & $\begin{array}{l}\text { Argentina }{ }^{*}, \text { Estonia, India*, Ireland, Italy*, Korea*, } \\
\text { New Zealand, Turkey*, United Kingdom }\end{array}$ \\
\hline \multirow[b]{2}{*}{ Existing radio programmes } & Slovak Republic & Australia ${ }^{\star}$, Colombia, Germany ${ }^{*}$, Lithuania \\
\hline & Japan $^{\star}$ & $\begin{array}{l}\text { Argentina }^{*}, \text { Colombia, Estonia, India } \\
\text { Zealand Korea }\end{array}$ \\
\hline \multirow{2}{*}{$\begin{array}{l}\text { New radio programmes especially designed to } \\
\text { support children's education during school } \\
\text { closures }\end{array}$} & Chile, Colombia & Ireland \\
\hline & Argentina*, Colombia, India*, Japan* & Estonia, Korea $^{*}$ \\
\hline
\end{tabular}

* $G 20$ countries are indicated with an asterisk.

* * G20 guest countries are indicated with a double asterisk.

Note: Items are sorted in descending order by the sum of response categories "major" and "moderate importance" in pre-primary education. Source: OECD Survey on Distance Education for Young Children in 2020. 


\section{Challenges and adaptations}

\section{Key messages}

- At both levels of education, the main challenges encountered by countries related to the capacity of families to support distance education activities, equipment and connectivity problems, and a shortage of digital tools and content specifically designed for young children.

- Results suggest that distance education solutions changed little across different periods of school/centre closures in 2020. A small number of countries provided information on how these measures evolved throughout the year.

- The pandemic accelerated the adoption of measures to protect young children from potentially harmful uses of digital technology, including recommendations for teacher and parents about screen time, advice to families about adult-supervised use of technology at home, and information on approaches to protect children's privacy and well-being in digital environments.

- There is substantial variation across countries in the perceived effectiveness of distance education in 2020, though a high level of uncertainty about such effectiveness is also reported.

This section describes the main challenges encountered by countries in using digital technologies for maintaining continuity of education, as well as the measures adopted to protect children from potentially harmful uses of technology. It concludes by looking at country reports on the perceived effectiveness of distance education in supporting young children's learning.

\section{Challenges}

The COVID-19 pandemic was unprecedented in many respects and countries had to respond in record time to the extraordinary challenge of maintaining education provision in a context of school/centre closures and, often, strict nation-wide lockdowns. While digital technologies provided a lifeline for continuity of education, their deployment presented many difficulties.

Responses to the survey indicate that, both at the pre-primary and primary levels of education, countries faced substantial challenges on at least three main fronts: digital infrastructure, families' engagement in remote learning, and the availability of digital solutions that are developmentally appropriate for young children.

Lack of equipment (e.g. tablets, computers) and lack of connectivity (access to the Internet) in children's homes were reported as "major" or "moderate" challenges in close to $70 \%$ of the countries participating in the survey. While also a reason for concern, equipment problems in schools/centres appeared less severe than in home settings, and were reported as "major" or "moderate" challenges by about $40 \%$ of countries in pre-primary education and by less than $30 \%$ of countries at the primary level. This suggests that, in terms of deficits in technical equipment and network infrastructure, the weakest link in the chain was found in children's homes, and points to the need to address inequalities in access by socio-economic background (Figure 4.1). 
Differences between children are likely to have been further amplified because of variation in the capacity of parents to provide effective support for distance education activities. At both levels of education, lack of time and low digital literacy/skills on the part of parents/caregivers were also reported as "major" or "moderate" challenges in over $70 \%$ of countries.

Another factor frequently reported as a "major" challenge, particularly at the pre-primary level, was the lack of or low quality of digital tools and materials specifically designed for children in the corresponding age groups. This suggests a relatively important mismatch between the digital tools used for maintaining distance education (many of which were not designed for educational purpose in the first place) with the learning and development principles that work best for young children.

Interestingly, countries reported greater inadequacies in terms of teachers' skills in using digital technology forlearning at the primary compared to the pre-primary level la "major challenge" for $33 \%$ and $12 \%$ of the countries, respectively), reflecting perhaps the greater intensity and type of reliance on digital tools expected in primary education. Also worth highlighting is the very low percentage of countries reporting major difficulties in relation to a potential reluctance from parents or teachers to use digital technologies for maintaining continuity of education.

Figure 4.1. Main challenges encountered in using digital technologies to maintain continuity of education for young children in 2020

Percentage of countries reporting different levels of severity, by level of education

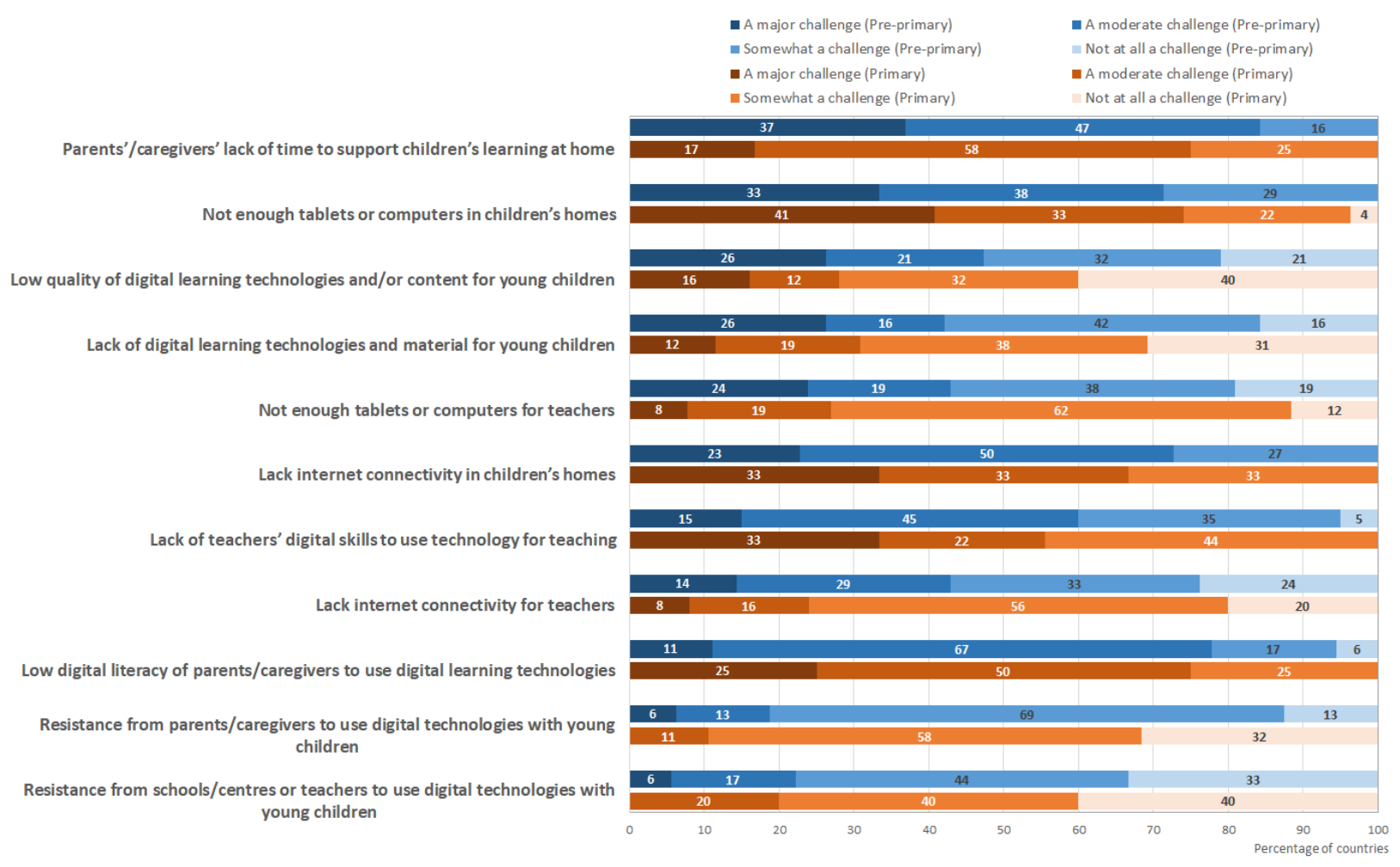

Notes: Only countries with displayed response categories are included in the analysis (i.e. "not known" and "not applicable" excluded from the percentages). Items are sorted in descending order by the response category "a major challenge" in pre-primary education. Source: OECD Survey on Distance Education for Young Children in 2020. 
In light of these challenges, countries adopted a wide range of measures to support both teachers and parents towards a better use of digital technologies in distance education. However, a large discrepancy in support provided to pre-primary versus primary teachers is visible in terms of the prevalence of ICT and distance education trainings and tools offered at each level (Figure 4.2). Participating countries consistently reported providing teachers at the primary level with greater guidance in terms of adapted context-specific lesson plans and pedagogical re-direction through online training workshops. Even in terms of equipment, greater emphasis was placed on the preparedness of primary teachers, ensuring their access to digital devices and Internet connectivity, as well as their proficiency in using them. As noted above, this may partly reflect a greater reliance on digital tools to reach primary level education objectives. Nonetheless, this uneven support for distance education across education levels in 2020 appears as a call for countries to explore a better articulation of digital technologies in the curriculum and pedagogical frameworks of pre-primary education, in order to better support the sector in responding to the challenges and opportunities of digitalisation in the coming years.

Figure 4.2. Measures to support teachers in using digital technologies for distance education during school/centre closures in 2020

Percentage of countries reporting system-wide implementation, by level of education

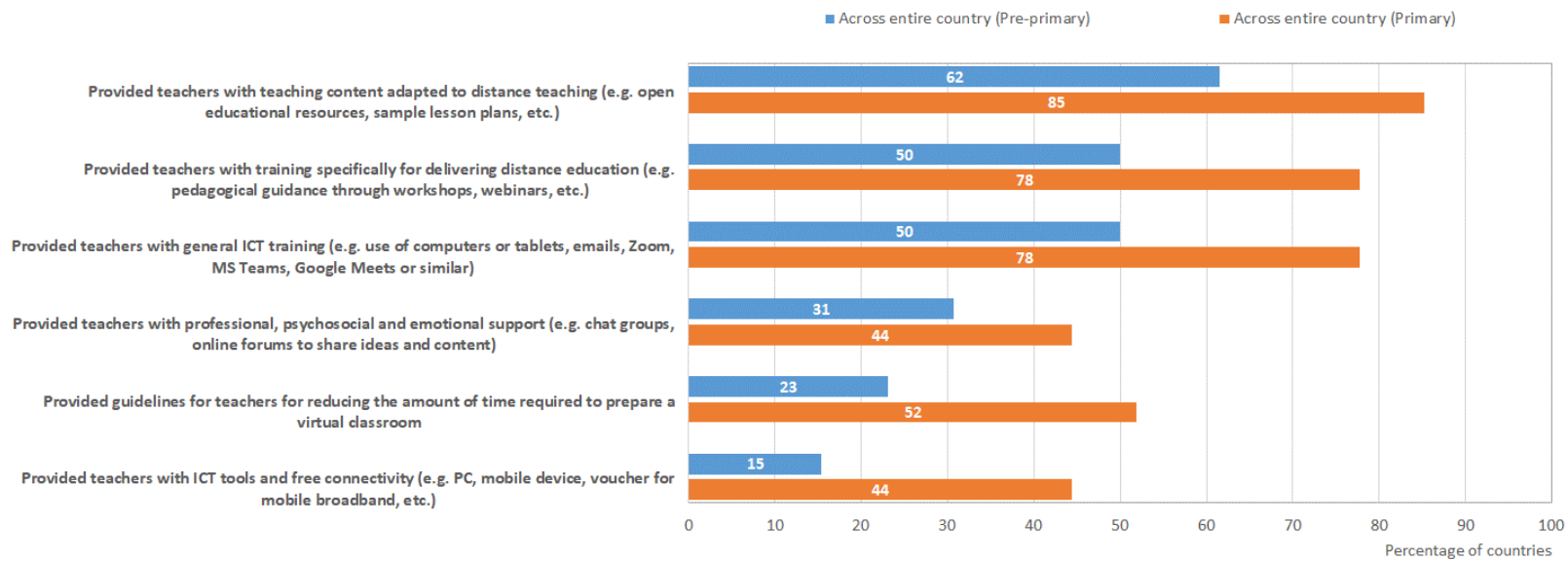

Note: Items are sorted in descending order by the response category "Across entire country" in pre-primary education.

Source: OECD Survey on Distance Education for Young Children in 2020.

Box 4.1. Examples from G20 countries: Measures to support teachers in using digital technologies for distance education

In Australia, state and territory government and non-government education authorities, and individual schools provided a range of supports to teachers in their access and use of digital technologies to maintain educational continuity during the period of remote learning. For example, the Australian state of New South Wales provided resources for teachers, including suggested structures for delivering learning at home; units of work for the first years of formal schooling; advice, training and resources for using technology; and on-demand online courses for professional learning. The Australian Curriculum, Assessment and Reporting Authority (ACARA) provided a clearinghouse for the sharing of resources across state and territory and sector jurisdictions and developed or sourced support for online and remote learning during the COVID- 19 pandemic. The Australian Institute of Teaching and School Leadership (AITSL) also provided a range of resources 
on its Teacher Resource Hub (the Hub) to support teachers moving to digital platforms for education delivery, including a best practice evidence guide for teachers on setting up online learning, as well as advice teachers could provide to parents and caregivers.

In Italy, the Ministry of Education supported schools during closures through the expertise of regional teams and the network of digital animators of the National Plan for digital schools. Moreover, the Government provided EUR $85 \mathrm{~m}$ to support distance learning with platforms, instruments and tools for schools, and training for teachers.

In Korea, the Ministry of Education designated 495 pilot schools to explore cases of best practice with the goal to upgrade capacity for online teaching and support all teachers nationwide. In addition, online teacher community platforms (e.g. School-On, Knowledge Spring) were created to exchange know-how and best practices for online teaching.

In Spain, virtual courses, webinars and MOOCs were organised at a regional and national level for training teachers in the use of digital tools. A new website ("Aprendo en casa") was launched to curate and make available online educational materials for teachers and families.

In England (United Kingdom), teachers were supported through the EdTech Demonstrator programme, a peer-peer support network designed to provide tailored support to schools and colleges specifically on remote education and use of technology in education, and a new digital service (Get Help with Remote Education) provided a one-stop-shop for teachers and leaders, signposting the support package available.

In Singapore, public pre-primary teachers were provided with laptops but not free connectivity at home. The Early Childhood Development Agency (ECDA) encouraged adoption of pre-approved Learning Management Solutions (LMS), which were vetted to provide safe, quality platforms to deliver home-based learning. Funding support was also provided for preschools to adopt LMS. ECDA also curated and shared the home-based activity resources developed by various preschools to support children's development while at home.

Source: OECD Survey on Distance Education for Young Children in 2020.

In parallel, families found themselves juggling priorities, with the majority of participating countries reporting that parents and caregivers of children at both levels of education considered time constraints as a "major" or "moderate" challenge to adequately support their children learning at home (Figure 4.1). In response to this interlocking of classroom and home environments, countries established practices to better connect teachers with parents and caregivers, ensuring mediums of communication and support for new instructional roles in children's homes. Digital technologies were a critical tool for maintaining the continuity of education and facilitating caregivers' experience. Top practices taken up by participating countries in both levels of education included consistent exchanges between caregivers and teachers through emails, texts and phone calls, as well as the provision of guides and online orientation sessions with teachers, all of which were more frequently implemented at the pre-primary level across participating countries (Figure 4.3). 
Figure 4.3. Measures to support parents/families for maintaining continuity of education in 2020 Percentage of countries reporting system-wide and partial implementation, by level of education

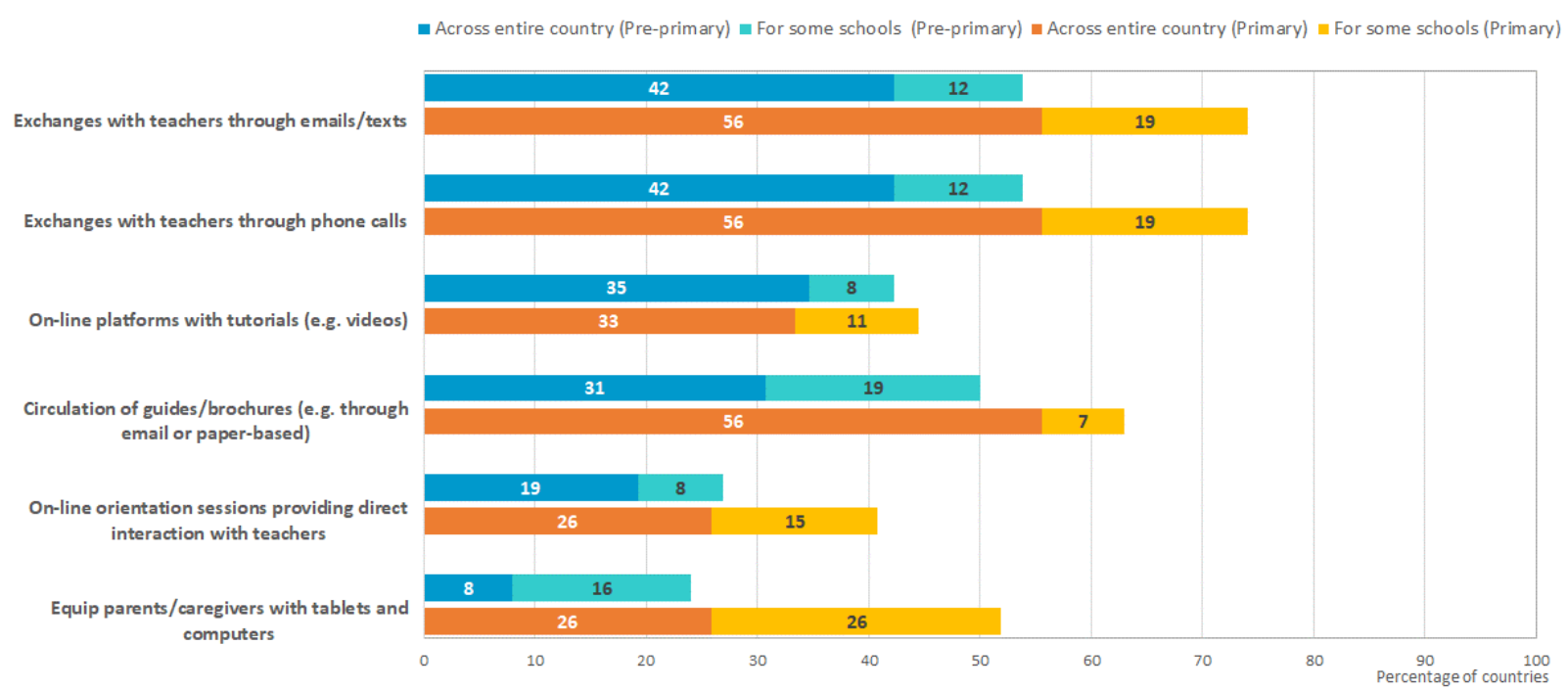

Note: Items are sorted in descending order by the response category "Across entire country" in pre-primary education. Source: OECD Survey on Distance Education for Young Children in 2020.

\section{A learning curve?}

The survey was designed to allow respondents to indicate up to three periods of school/centre closures throughout 2020, as well as answer a number of questions with respect to each of these periods specifically. The goal wastocollect not only more granular information about the number and length of periods of closure, butalso onwhether the measures adopted to maintain continuity of education for young children evolved in the course of 2020. Within-country changes in measures across periods of closure could be indicative of gradual adjustments in responses to the crisis, which in turn could be due to changes in the circumstances imposed by the pandemic and/or to knowledge gained thanks to early responses.

Given the small number of countries reporting more than one substantial period of closure in 2020 (see above), the data collected through the survey provides limited opportunities to analyse whether countries went through a"learning curve" in 2020 with respect to the adequate measures to maintain continuity of education for young children. Figure 4.4 shows the reported importance of digital technologies enabling real-time classes or activities between teachers and children in primary education across multiple periods of school/centre closure inthetencountries for which this information is available (Austria, Belgium [Flanders], Czech Republic, Denmark, India, Korea, Lithuania, Netherlands, Norway and Turkey). Results suggest a large degree of stability intheimportance that such digital solutions played across periods of closure in these countries. It is only in Austria and Denmark that some variation over time is observed: in both countries, digital technologies enabling real-time classes or activities had a role of "moderate" importance during initial closures, but were reported to become of "major importance" in later ones.

At the pre-primary level, the information is available for only four countries (Belgium [Flanders], Colombia, Germany and Slovak Republic), and in all of them the reported importance of this type of technologies remained the same between the first and the second periods of closures in 2020, regardless of the actual level of importance. 
Figure 4.4. Use of digital technologies for real-time activities across periods of closure in 2020

Reported importance of digital technologies enabling real-time classes or activities between teachers and children in primary education across periods of school/centre closure in 2020

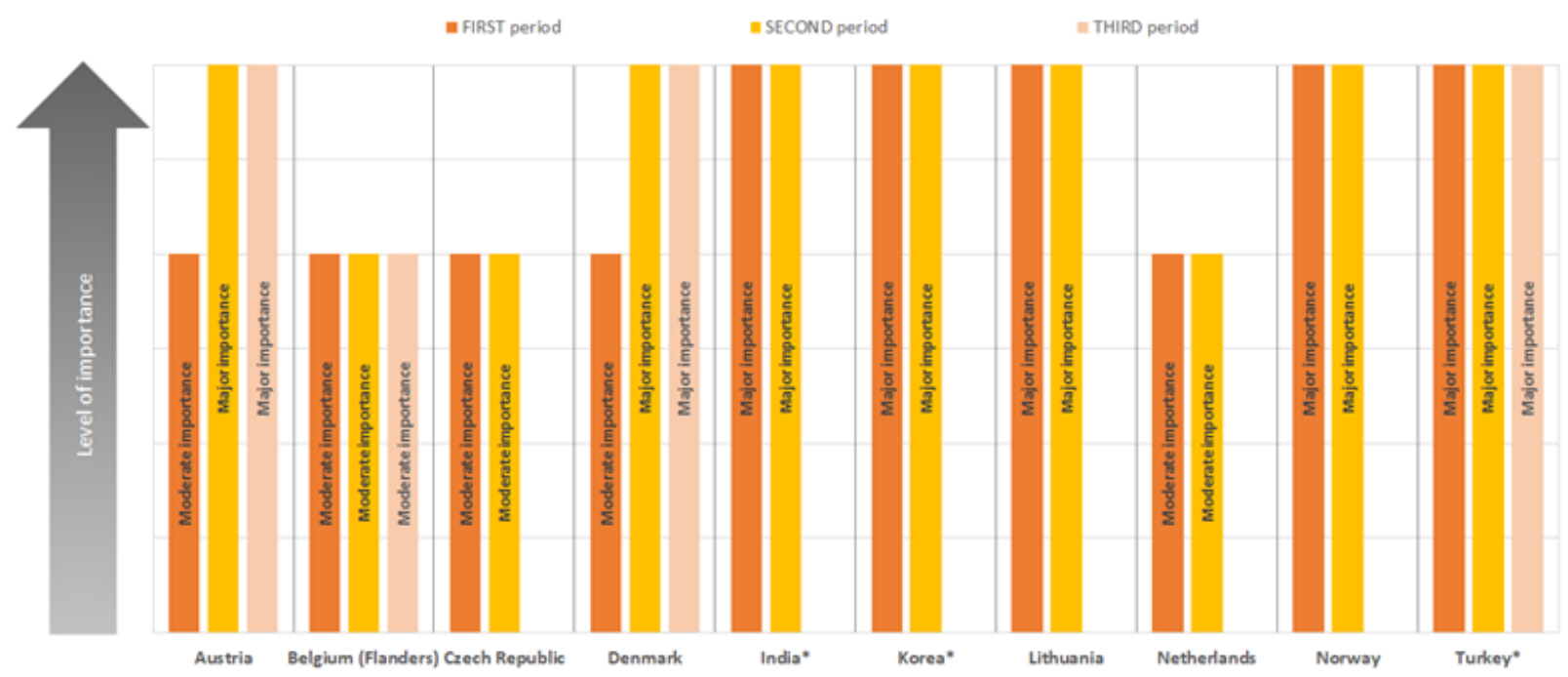

* $\mathrm{G} 20$ member countries are indicated with an asterisk.

Note: Only countries with more than one period of school/centre closure are shown.

Source: OECD Survey on Distance Education for Young Children in 2020.

While results must be interpreted with much caution given the low number of countries reporting multiple periods of closure and their limitation to a single indicator of the nature of countries' responses to the crisis, they suggest stability in the measures adopted by countries throughout 2020. This pattern of stability may be tentatively interpreted as a sign that, in the course of the first year of the pandemic, there was still little scope for countries to draw robust conclusions about the most adequate tools or strategies to maintain continuity of education for young children. Going forward, however, lessons from the experience of 2020 will be crucial to improve preparedness. Results from this survey seek to contribute to this stocktaking exercise.

\section{Protecting children against digital risks}

Digital technologies have become increasingly present in children's lives over the last decade. Recent evidence documents that children's exposure to and use of digital devices occurs at increasingly younger ages, with growing shares of children becoming familiarised with digital technologies in their home environments before they start pre-school (Hooft Graafland, 2018[15]). The COVID-19 pandemic heightened this trend as lockdowns forced children and parents to rely on digital tools in daily interactions for education and work purposes. A greater exposure to digital environments in 2020 brought also a greater need to protect young children against inappropriate and potentially harmful impacts of technology.

An important finding from the survey is that the adoption of measures aimed at protecting children from potential risks associated with the use of digital technology accelerated in 2020 (Figure 4.5). Prior to the pandemic, less than a third of participating countries had recommendations for teachers about screen time for young children (27\% of countries at the pre-primary level and $31 \%$ at the primary level), but in 2020 the number of countries issuing such recommendations to teachers more than doubled (with an additional $35 \%$ of countries at the pre-primary level and $46 \%$ at the primary levell). Similarly, the experience of distance education in 2020 led many countries 
to disseminate advice to parents and families about adult-supervised use of technology for children (37\% at pre-primary level and $28 \%$ at the primary level).

Other measures such as information for parents and families about children's privacy online or about the risks of digital technologies for children's physical health or emotional well-being were more commonly already in place in G2O and OECD countries prior to the pandemic, and a smaller share of countries introduced them in 2020. Nonetheless, it is noteworthy that the adoption of all the measures covered in the survey expanded in 2020, providing a strong indication that awareness about digital risks and the need to address them both in school/centre and family environments grew alongside the increased reliance on digital solutions in 2020. In India, for instance, training for primary education teachers to help children and parents/caregivers use digital technologies in appropriate ways was in place prior to the pandemic, but six other measures addressed to both parents and teachers were adopted in 2020.

Figure 4.5. Measures to protect young children against risks of digital technologies

Percentage of countries adopting each measure prior to and in 2020, by level of education

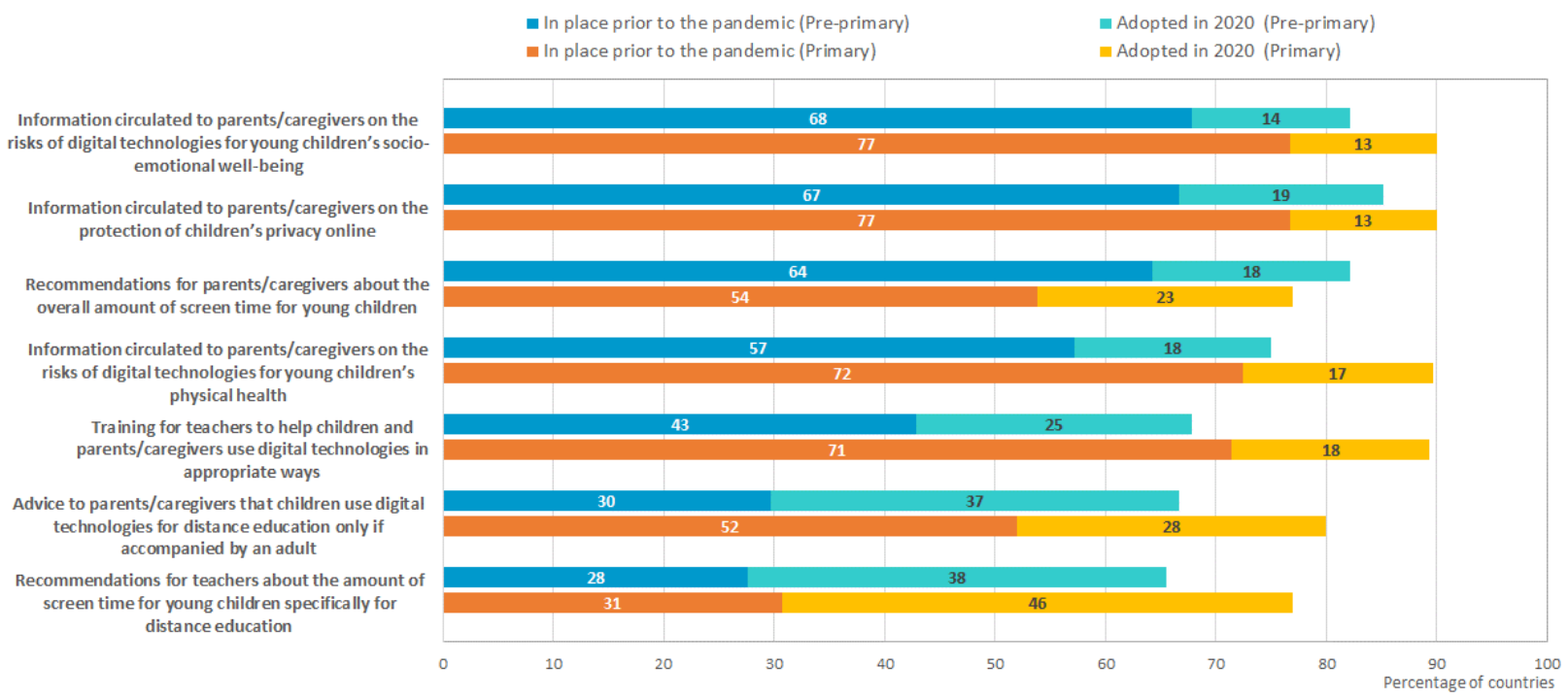

Note: Items are sorted in descending order by the response category "In place prior to the pandemic" in pre-primary education.

Source: OECD Survey on Distance Education for Young Children in 2020.

A number of examples are available from additional information provided by countries. The Australian Government, for instance, published 24-hour movement guidelines with information and advice about the amount and type of physical activity required for health benefits, limiting sedentary behaviour and getting adequate sleep. These guidelines include recommendations around hours spent on recreational screen time. Online safety information for parents, teachers and students was also published through the Office of the E-Safety Commissioner. This includes information and advice to parents and caregivers to encourage them to use devices in open areas of the home, to co-view and co-play with their children online, and to know the apps, games and social media sites their children are using. In Italy, several measures for the protection of children in digital environments were confirmed and implemented in 2020 with the issuing of the Guidelines for Integrated Digital Learning (DDI).

Countries having taken action to address concerns regarding data privacy in the course of distance learning include Finland, where guidelines to education providers on the data protection of learners were updated, and Portugal, 
where a set of security measures for the use of digital platforms elaborated by the National Data Protection Commission was distributed to ECE centres and primary schools.

The increased rate of adoption of measures for protecting children from digital risks in 2020 added momentum to a well-established trend, but the rapid pace of technological developments and the evolving nature of digital risks will require $G 20$ and $O E C D$ countries to remain vigilant in order to update and strengthen their strategies in this area (Burns and Gottschalk, $2019[16])$. The Recommendation on Children in the Digital Environment adopted by the OECD Council in 2021, which reviewed the Recommendation on the Protection of Children Online of 2012, represents an important development in this direction (OECD, $\left.2021_{[17]}\right]$. The Recommendation seeks to assist governments and other actors in implementing coherent policies and procedures to address the delicate trade-off between enabling the opportunities that the digital environment can bring to children and protecting them from associated risks.

\section{Perceived effectiveness}

This study did not attempt to generate evidence about the effects of distance education arrangements during the COVID-19 pandemic. Nonetheless, in order to complement the insights about the extent and modalities of distance learning presented in preceding sections, the survey sought to collect high-level assessments of the perceived effectiveness of distance education in supporting young children's learning and development in 2020. It is important to underline that, even when based on actual assessments of children's learning outcomes carried out by countries, these perceptions from the education authorities responsible for answering the survey constitute at best a crude way of evaluating the relative contribution of distance education to such outcomes. More systematic and robust analyses are needed before sound claims can be made regarding the effectiveness of distance education arrangements.

Despite multiple challenges, many G20 and OECD countries are making efforts to monitor trends in the learning outcomes of young children and to assess the impact of the disruptions caused by the pandemic. At the pre-primary level, ten of the countries participating in the survey reported that measures to assess children's learning outcomes after the school/centre closures in 2020 had been implemented, whereas at the primary level up to 15 countries reported such measures.

During the pandemic, nonetheless, several countries chose to modify their assessments of learning outcomes. In Australia, for instance, national student testing programmes at the school level were halted during 2020, but are scheduled to resume in 2021 . Similarly, Portugal, made adjustments to its assessment system and cancelled the benchmark tests designed to assess learning progress in several curriculum content areas in primary education. France issued guidelines for primary teachers for adopting a benevolent approach ("bienveillance") and ensure formative monitoring and support, based on regular contact with learners and families. In the United Kingdom, while the requirement to carry out and report on formal statutory assessments in Northern Ireland was eased, schools used multiple formative assessment methods to assess their children's learning during the period of school closure, while in Wales notices were issued modifying the basic curriculum and associated assessment requirements, in particular the Foundation Phase Profile, an observational and formative assessment used to support judgements and track children's progress on the curriculum for 3 to 7 year olds. In England, many primary schools also kept using formative assessment tools during 2020, but systematic assessment did not take place.

Many countries reported that evaluation efforts are ongoing, and that studies have been commissioned about the extent and factors associated with potential learning losses. Research in this area is beginning to emerge, with some studies addressing specifically the learning outcomes of children in primary and pre-primary levels of education (e.g. (Bao et al., 2020 [18]; Blaskó, da Costa and Schnepf, $2021_{[19] ;}$ Engzell et al., $2021_{[20] \text {; Rose }}$

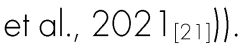


Responses to the survey suggest that countries remained cautious with regard to evaluating the effectiveness of distance education in supporting children's learning and development in 2020. Both at the pre-primary and primary levels of education, about $40 \%$ of the countries reported a "moderate" effectiveness of distance education, while four countries and jurisdictions (Australia [Queensland], Japan, Korea and Turkey) reported it as "highly effective" in the early years of primary education (Figure 4.6). Importantly, however, a substantial share of participating countries (54\% at the pre-primary level and 35\% at the primary level) reported not knowing what the effectiveness of distance education solutions had been. This high level of uncertainty points to the need for further research on the impact of remote learning arrangements.

Figure 4.6. Perceived effectiveness of distance education in 2020

Percentage of countries reporting different levels of effectiveness, by level of education

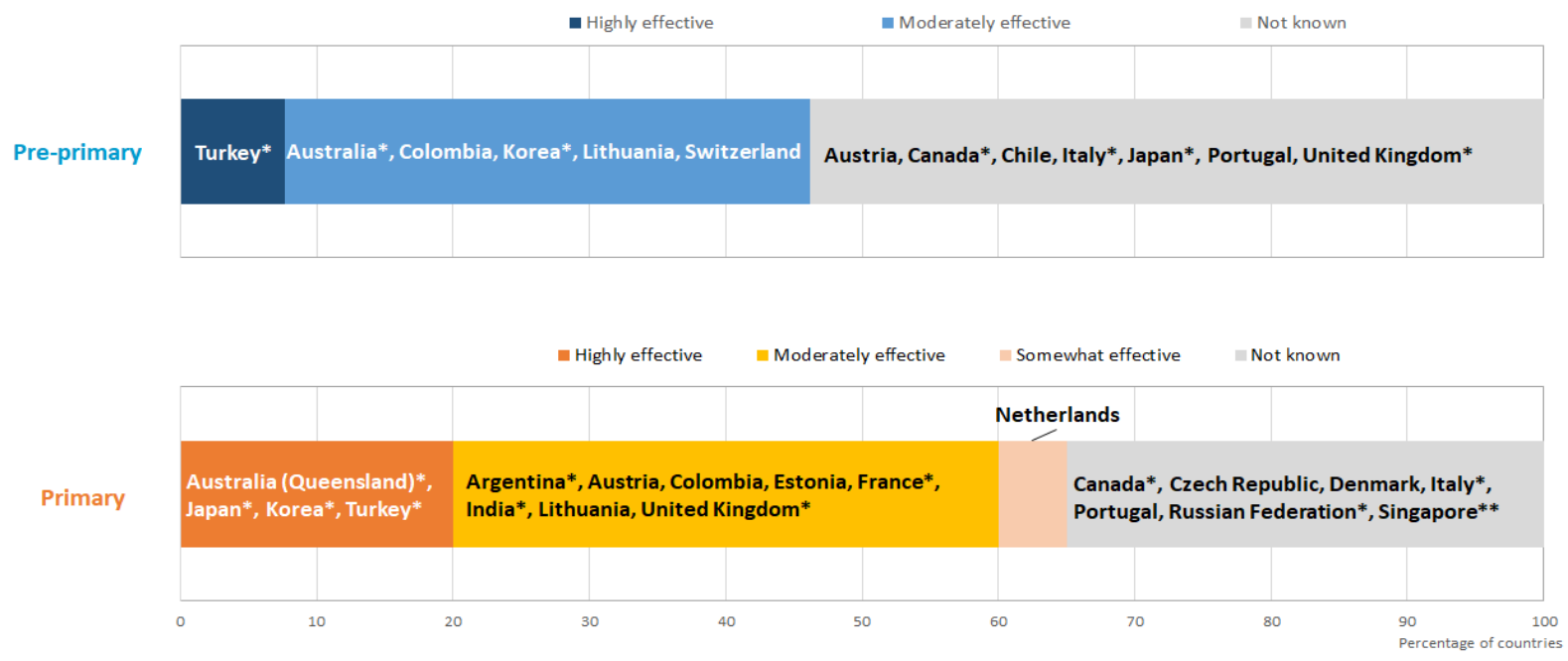

* G20 member countries are indicated with an asterisk.

** G20 guest countries are indicated with a double asterisk.

Source: OECD Survey on Distance Education for Young Children in 2020. 


\section{5 Supporting vulnerable groups of young children during distance education}

\section{Key messages}

- Across countries participating in the survey, and at both levels of education, maintaining continuity of education was particularly challenging for children from socio-economically disadvantaged backgrounds and for children with special education needs.

- Infrastructure, lack of material and families' limited availability and resources were the main difficulties identified in maintaining continuity of education for socio-economically disadvantaged children andrefugee children. A lack of adequate digital learning materials adapted to children's circumstances was an important obstacle to providing distance education for those with special education needs, those whose first language is different from the language of instruction in their schools/centres, and those from indigenous communities.

- In 2020, about $40 \%$ of countries participating in the survey provided targeted support to socio-economically disadvantaged families, for instance through phone calls or emails to parents/caregivers, in their efforts to maintain children's learning at home. Other common measures, especially at the primary level, included the provision of digital devices to families at risk of being excluded from distance education, and the provision of digital content adapted to children with special education needs. Countries reported moderate levels of success with these measures.

The COVID- 19 pandemic disrupted education in unprecedented ways and research is still needed on its potential impact on learners in the medium and long run. Across countries, however, an immediate and paramount concern about the transition to distance education was the potential increase of inequalities in learning opportunities and outcomes for children of different social groups. Learning gaps between children could grow as a result of uneven access to material resources and support in home environments, and from a limited capacity of early education centres and schools to adequately support vulnerable young children remotely. Responses to the survey indicate that the experience of replacing in-person education with distance and hybrid modes of delivery varied across groups of young children, and that countries encountered greater difficulties in trying to maintain continuity of education for children in disadvantaged and minority groups. However, as evidence shows that digital alternatives to in-person education tend not to be equally accessible and effective for all children, G2O and OECD countries sought to put in place mitigation measures specifically aimed at supporting vulnerable young children. 
Results from the survey indicate that, across countries, socio-economic disadvantage and special education needs were the two main factors associated with difficulties in maintaining continuity of education during the first period of school/centre closures in 2020 (Figure 5.1). At the pre-primary level, $80 \%$ of countries report that implementing distance education for children from socio-economically disadvantaged homes was "more" or "much more" challenging than for other groups of children; and $63 \%$ of countries report the same difficulties at the primary level. Attending to children with special education needs (e.g. children with learning disabilities, physical impairments and/or those who suffer from mental disorders) proved to also be "more" or "much more" challenging than ensuring continuity of education for other groups of children in around two-thirds of countries at either level of education.

A smaller number of countries provided information on the extent to which maintaining continuity of education posed particular challenges for children whose first language is different from the language of instruction in their early education schools/centres, for children from indigenous communities, or for children who are refugees. The reduced number of responses to these questions arguably reflects variation in the relative size of the above-mentioned groups within participating countries. However, among countries reporting on these groups, challenges are comparable to those faced in providing distance education for children in other vulnerable groups, suggesting that the factors associated with difficulties in access to and suitability of digital learning resources extend beyond socio-economic disadvantage and special education needs.

Figure 5.1. Groups of young children at risk of exclusion from distance education in 2020

Percentage of countries reporting the extent of challenges for each group, by level of education

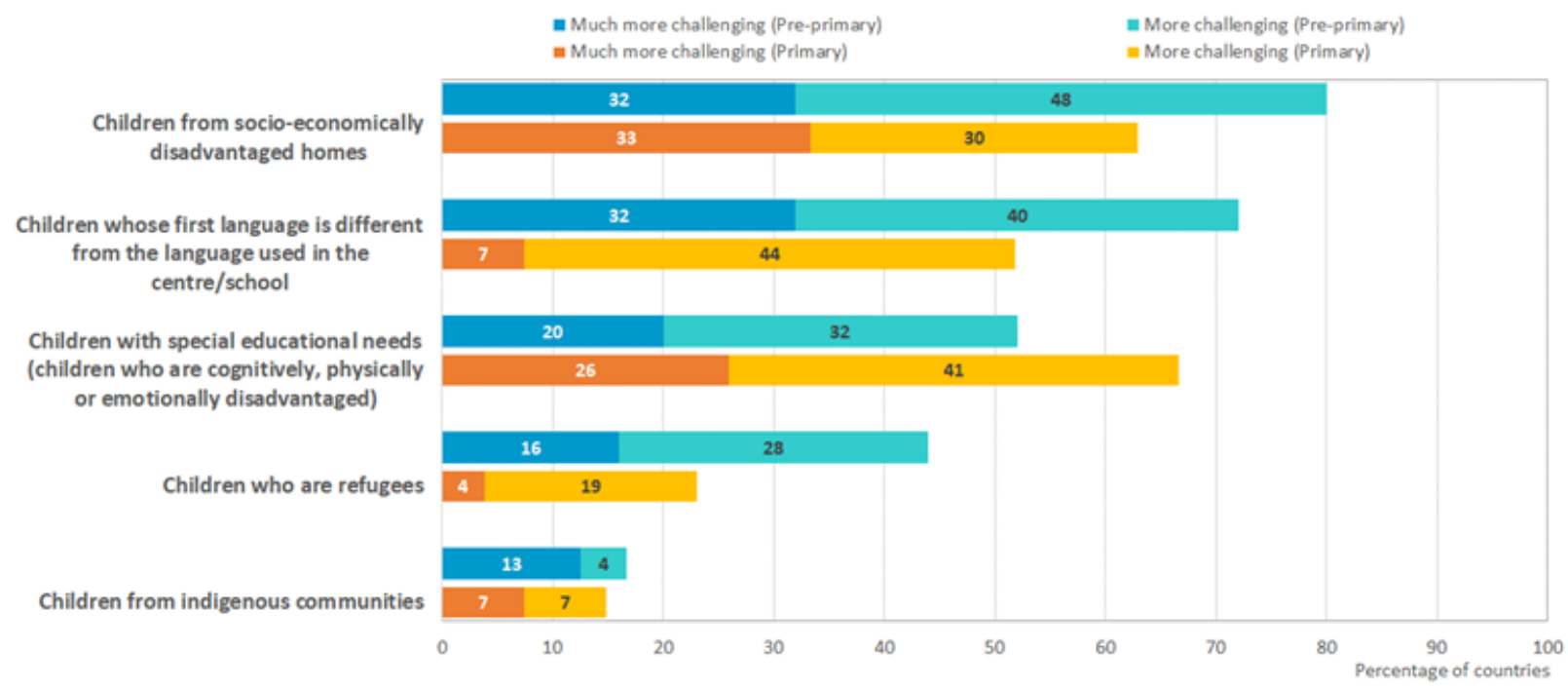




\begin{tabular}{|c|c|c|}
\hline & & List of countries \\
\hline & Much more challenging & More challenging \\
\hline \multirow{2}{*}{$\begin{array}{l}\text { Children from socio-economically } \\
\text { disadvantaged homes }\end{array}$} & $\begin{array}{l}\text { Australia*, Canada*, Chile, Czech } \\
\text { Republic, Lithuania, Portugal, Spain**, } \\
\text { Switzerland }\end{array}$ & $\begin{array}{l}\text { Austria, Belgium (Flanders), Colombia, France*, Germany", } \\
\text { Ireland, Italy*, Luxembourg, Singapore }{ }^{*} \text {, Slovak Republic, } \\
\text { Turkey", United Kingdom* }^{*}\end{array}$ \\
\hline & $\begin{array}{l}\text { Argentina*, Belgium (Flanders), Colombia, } \\
\text { Czech Republic, Denmark, Ireland, Italy*, } \\
\text { Portugal, Slovak Republic }\end{array}$ & $\begin{array}{l}\text { Finland, France }{ }^{*} \text {, Lithuania, Netherlands, New Zealand, } \\
\text { Spain }^{* *}, \text { Turkey }^{*}, \text { United Kingdom }\end{array}$ \\
\hline \multirow{2}{*}{$\begin{array}{l}\text { Children whose first language is different } \\
\text { from the language used in the } \\
\text { centre/school }\end{array}$} & $\begin{array}{l}\text { Australia*, Canada*, Chile, Czech } \\
\text { Republic, Ireland }\end{array}$ & $\begin{array}{l}\text { Austria, Belgium (Flanders), France*, Germany*, Italy*, } \\
\text { Slovak Republic, Spain**, Switzerland }\end{array}$ \\
\hline & Czech Republic, Italy* & $\begin{array}{l}\text { Argentina*, Australia (Queensland)*, Austria, Belgium } \\
\text { (Flanders), Finland, France* }^{*} \text { Ireland, Lithuania, } \\
\text { Netherlands, Norway, Slovak Republic, United Kingdom }\end{array}$ \\
\hline \multirow{2}{*}{$\begin{array}{l}\text { Children with special educational needs } \\
\text { (children who are cognitively, physically or } \\
\text { emotionally disadvantaged) }\end{array}$} & $\begin{array}{l}\text { Australia*, Canada*, Chile, Colombia, } \\
\text { Germany*, Lithuania, Spain**, Switzerland }\end{array}$ & $\begin{array}{l}\text { Austria, Belgium (Flanders), Czech Republic, France }{ }^{*} \text {, } \\
\text { Ireland, Italy*, Korea*, Portugal, Singapore }{ }^{* *} \text {, Slovak } \\
\text { Republic }\end{array}$ \\
\hline & $\begin{array}{l}\text { Argentina*, Colombia, Denmark, Finland, } \\
\text { Ireland, Italy*, Slovak Republic }\end{array}$ & $\begin{array}{l}\text { Austria, Belgium (Flanders), Czech Republic, Estonia, } \\
\text { France }^{*} \text {, Korea*, Lithuania, Norway, Portugal, Spain } \\
\text { United Kingdom** }\end{array}$ \\
\hline \multirow{2}{*}{ Children who are refugees } & Australia*, Canada*, Chile, Spain ${ }^{* *}$ & $\begin{array}{l}\text { Austria, Colombia, Germany*, Ireland, Italy*, Luxembourg, } \\
\text { Switzerland }\end{array}$ \\
\hline & Italy* & Austria, Ireland, Netherlands, Norway, Spain ${ }^{* *}$ \\
\hline \multirow[b]{2}{*}{ Children from indigenous communities } & Canada*, Chile, Ireland & Colombia \\
\hline & Colombia, Ireland & Argentina* $^{*}$, Australia (Queensland) ${ }^{*}$ \\
\hline
\end{tabular}

* G20 member countries are indicated with an asterisk.

** G20 guest countries are indicated with a double asterisk.

Note: Items are sorted in descending order by the sum of response categories "much more challenging" and "more challenging" in pre-primary education.

Source: OECD Survey on Distance Education for Young Children in 2020.

Unsurprisingly, infrastructure, lack of material, and families' limited availability and resources were reported as the main reasons behind difficulties in providing distance education to children from socio-economically disadvantaged groups and children who are refugees. However, for other vulnerable groups such as children with special education needs, children whose first language is different from the language of instruction in their schools/centres or children from indigenous communities, the lack of adequate digital learning materials and solutions to meet their specific education needs appeared as the most important obstacles. This highlights the need for digital education programmes to include equity-oriented measures that go beyond provision and equipment, and to incentivise the development of digital tools and content specifically designed for children with a broad range of needs and abilities, including those related to linguistic and cultural backgrounds, rather than assuming that standard technology solutions serve all children equally (see Table A.4 in the Annex).

Results from the survey align with research undertaken in countries as the pandemic unfolded with the goal to identify vulnerable groups of young learners and inform policy responses. For example, research commissioned by the Australian Government in April 2020 found that students most likely to experience disruptions to their learning progress included those with complex learning needs or a disability; students in regional, rural and remote locations; students from a language background other than English; or students from low socio-economic backgrounds. Early research also raised a number of distinct implications related to remote learning for Aboriginal 
and Torres Strait Islander students, including reduced opportunities to both work closely with Aboriginal and Torres Strait Islander teaching staff and engage with learning experiences that support culturally responsive pedagogies. In New Zealand, a survey conducted by the Education Review Office found that many early childhood education centre leaders reported challenges to support learning during the lockdown due to a lack of connectivity and digital equipment in children's households, including in rural areas with poor Internet coverage.

Some countries put in place various specific measures in 2020 to facilitate continuity of education for vulnerable children (Figure 5.2). Targeted support to socio-economically disadvantaged families to continue children'slearning and development at home, provided for instance through phone calls or emails to parents/caregivers, was one of the measures most commonly implemented, by approximately four in ten countries at each level of education. Other measures commonly adopted by countries, especially at the primary level, focused on access to equipment, such as the provision of computers/tablets to families at risk of being excluded from distance education, and the provision of digital tools and content adapted to children with special education needs. Moreover, one-third of participating countries provided materials adapted to children speaking minority languages. Importantly, countries also provided information on the success of these initiatives. Mostmeasures were reported to have reached "a majority" of their targeted beneficiaries in about half of the implementing countries, and to have reached "about half" or "a minority" of the targeted beneficiaries in the rest of the countries where these measures were in place.

Figure 5.2. Measures implemented to support children in vulnerable groups in accessing distance education in 2020

Percentages of countries reporting implementation, by level of education

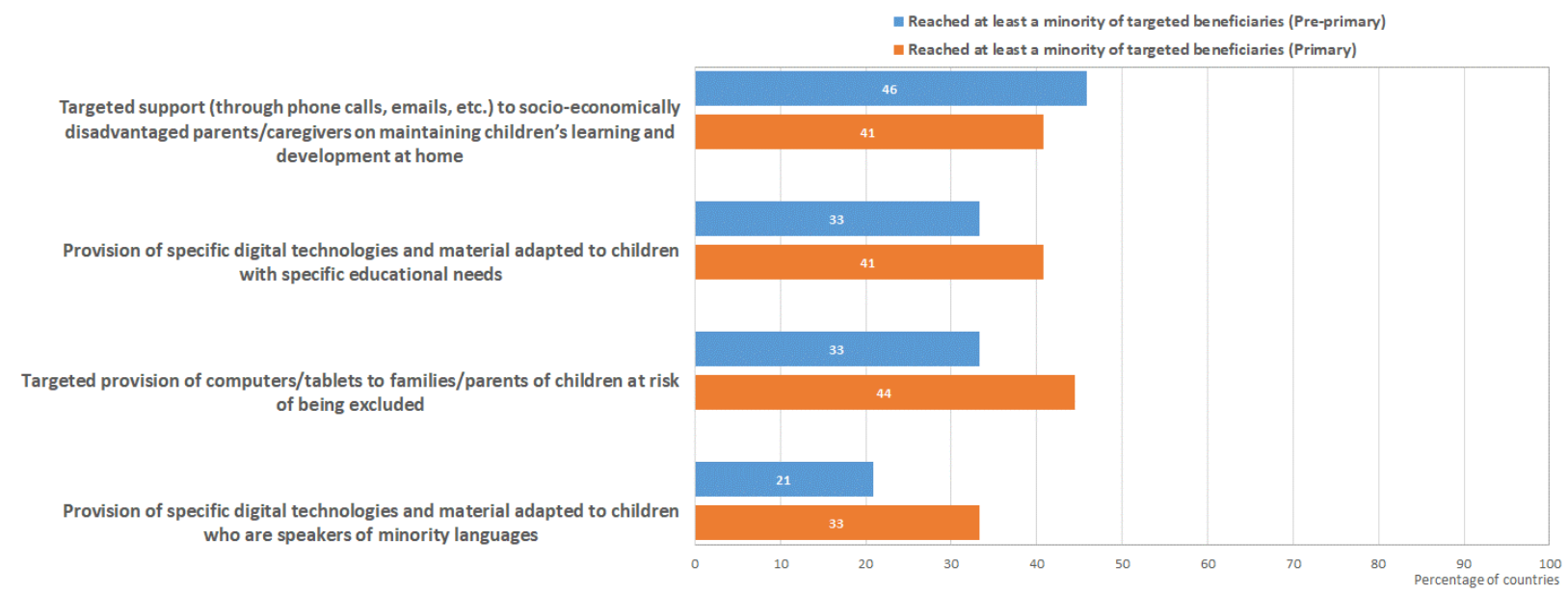

Note: Items are sorted in descending order by the response category "Reached at least a minority of targeted beneficiaries" in pre-primary education.

Source: OECD Survey on Distance Education for Young Children in 2020.

Information provided specifically on initiatives to support young children with special education needs illustrates the variety of approaches that countries took to protect this vulnerable group in the context of the pandemic. For instance, in Italy, priority was given to children with disabilities or special education needs to attend the early childhood education centres and schools that remained open during the partial closures; further, home visits by education assistants were offered in cases where these children could not attend school- or centre-based activities, as well as during general lockdown. Similarly, in Germany children with special education needs were one of the groups allowed to attend early childhood education centres during lockdowns, as well as given 
priority access to childcare centres in the process of stepwise re-opening. In Portugal, since 2009, children with disabilities in pre-primary and primary levels of education have been entitled to financial support for purchasing digital devices - an entitlement that was guaranteed during the pandemic. In addition, in 2020, Portugal issued guidelines for remote teaching and disseminated them to early childhood education centres and primary schools, including for multidisciplinary support teams to foster inclusive education and for the bilingual teaching of learners with hearing impairments.

In Singapore, the government-funded Early Intervention Programme for Infants and Children (EIPIC) is geared to young children with special developmental conditions and delivered at early intervention (El) centres. These El centres frequently communicated with parents/caregivers through video-conferencing, phone calls, and text messages to check on the well-being of family members, and provided advice on strategies to better cope with any challenging behavioural issues. Moreover, during the pandemic, corporate partners sponsored digital devices, mobile routers, and SIM cards for families in the KidSTART programme who indicated that they had an insufficient number of digital devices at home. KidSTART is a national programme which provides upstream support for children of up to 6 years old from low-income families.

In Colombia, the "Mis Manos te Enseñan" initiative was launched by the Instituto Colombiano de Bienestar Familiar (ICBF) in response to the temporary closure of Early Childhood Development (ECD) Services to support children and pregnant women in vulnerable groups across the country. The first phase focused on providing food rations and a family guide promoting care and child-rearing practices (with activities, recipes and recommendations for care and safetyl. Additionally, staff from ECD services guided parents and caregivers on simple pedagogical activities to foster child development at home using age-relevant routine activities. The second phase adopted a more comprehensive, multi-modal response, during which pedagogical kits were distributed to support parents in carrying-out the activities featured in the family guide, and phone-based psychological support was provided for at-risk children and pregnant women to identify and help cope with social, emotional and behavioural stress (Gutiérrez Bernal et al., 2020[22]).

Moving beyond the pandemic, it will be essential that digital education strategies take into account the intersectionality of social disadvantage and diversity among young children, establishing requirements andincentives for distance learning solutions to address the needs of all children, and particularly those from the most vulnerable groups. 


\section{Strategies going forward}

\section{Key messages}

- The pandemic acted as a catalyst for rethinking policies regarding the use of digital technologies in early education. Both at the pre-primary and primary levels, more than $75 \%$ of countries participating in the survey report having changed their approaches to integrating digital technologies following their experience with distance education in 2020.

- Among the strategies envisaged to integrate digital technologies in early education by 2025, workforce training is countries' top priority, followed by the development of digital learning tools specifically designed for young children.

- In the coming years, most countries plan to strengthen the preparation of early education professionals for distance education through both pre-service and in-service training programmes. Yet, fewer countries report planning to increase training budgets, with the risk that training on the use of digital technologies may come at the expense of other areas of professional development. Plans to reform accountability and quality frameworks to account for increased use of distance education are also relatively rare.

For education systems worldwide, the importance of drawing lessons from the COVID-19 pandemic cannot be overstated. The school/centre closures of 2020 may herald challenges to be encountered again in a not so distant future. The crisis exposed gaps and inequities in early childhood education and school systems, from infrastructure shortages to a lack of preparedness for adapting practices and enabling local initiatives (OECD, $\left.202 l_{[6]}\right]$. At the same time, the pandemic likely accelerated underlying trends related to digitalisation, bringing investment and capacity needs to the spotlight and to countries' education policy agendas.

Results from the survey suggest that the experience also propelled countries into rethinking their policies about the use of digital technologies in early levels of education. Four-fifths (79\%) of countries reported that the pandemic led to changes in their approach for integrating digital technologies at the pre-primary level, of which one-third (34\%) reported a substantial change and almost half (45\%) reported a moderate change. At the primary level, the extent of changes appears even larger with $88 \%$ of countries reporting that their approaches changed as a result of the pandemic, including $42 \%$ reporting a substantial change and $46 \%$ a moderate change. Countries reporting having changed their approaches substantially at both levels are Belgium (Flanders), Colombia, Italy, Japan and Portugal, while Argentina, Australia (Queensland), Chile, India and Switzerland also report such changes at the level in which they participated in the survey. New Zealand is the only country reporting not having changed prior approaches at either level following the pandemic (see Table A.5 in the Annex), having a work programme under way to adapt its national curriculum to include learning with digital technologies.

The survey also collected information on the strategies envisaged by countries to integrate digital technologies in early levels of education by 2025 (Figure 6.1). Results indicate that strengthening early education teachers' training on the use of digital technologies is considered a high priority for close to $60 \%$ of countries at the pre-primary level, and for $80 \%$ of countries at the primary level, placing it as the most commonly envisaged 
strategy for the coming years. Another area where countries reported a strong interest is the development of digital resources designed specifically for young children, including adaptive technologies for a greater personalisation of learning and response to children's individual needs, especially at the primary level where these strategies are listed as a high priority by more than $50 \%$ of survey participants.

The integration of digital tools in the work of early education teachers outside their interactions with children, either for administrative duties, for communicating with parents and families, or for professional development purposes, is also a "high" or "moderate priority" for about two-thirds of survey participants, at both the pre-primary and early years of primary levels. In turn, further investments in equipment are also envisaged by a large share of countries, being a "high priority" for $45 \%$ at the primary level and $30 \%$ at the pre-primary level.

Results also suggest that many countries envisage these actions as complementary to each other and as part of a broader strategy to respond to an increasing digitalisation of early education in the near future. Estonia, Korea, Saudi Arabia and Spain reported that all the specific actions covered in the survey will constitute high priorities in the coming years, at both levels of education.

Figure 6.1. Strategies to integrate digital technologies in early education by 2025

Percentage of countries assigning a "high" or "moderate priority", by level of education

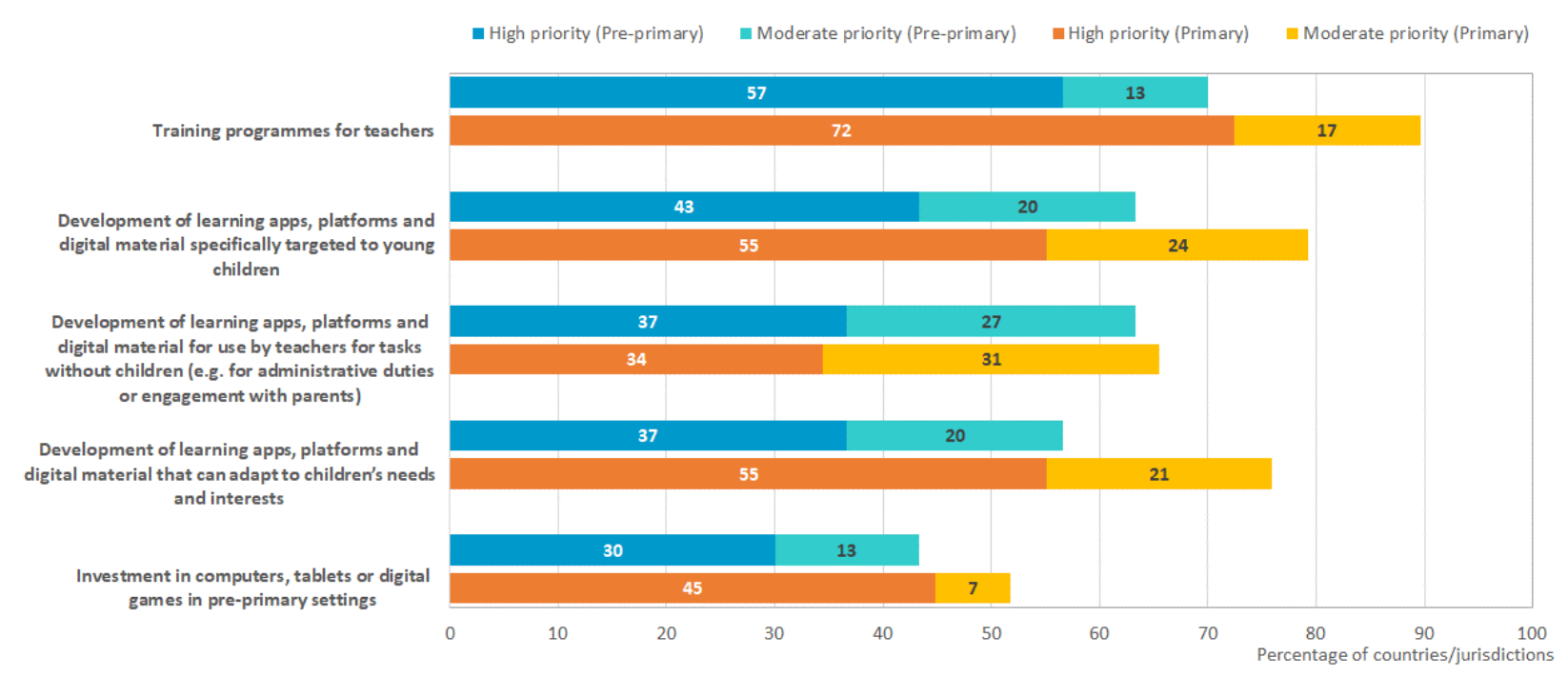

* G20 member countries are indicated with an asterisk.

** G20 guest countries are indicated with a double asterisk.

Note: Items are sorted in descending order by the sum of response categories "high" and "moderate" priority in pre-primary education. Source: OECD Survey on Distance Education for Young Children in 2020.

A number of countries provided additional information regarding specific strategies. Ireland already placed a high priority on embedding digital technology in teaching and learning accompanied with dedicated investment to build capacity in school infrastructure and professional development at the primary level as part of its Digital Strategy for Schools 2015-20. Thus, the high priority assigned to teacher training and the design of digital learning materials by 2025 can be seen as an extension of efforts in the years prior to the pandemic. In New Zealand, professional learning for primary teachers will also put an emphasis on digital fluency, supported by the development of a new online curriculum platform. Portugal reports that better equipping early childhood education centres and primary schools with digital devices will become a high priority alongside investments in teacher training. Finland has acknowledged the need to strengthen research on the impact of the use of technology on children's learning. In addition, Finland is conducting a collaborative development 
programme of the Finnish Teacher Education. At the pre-primary level, Luxembourg will prioritise efforts to strike the right balance between the use of digital materials and devices and the protection of children from excessive consumption and screen time.

The survey provides further insights into the measures planned by countries to support early education teachers' professional learning regarding the use of digital technologies (Figure 6.2), which is the strategy reported as a high priority by the largest number of countries. The most commonly envisaged measure is the development of in-service training programmes on remote/hybrid teaching and related ICT skills, planned for $50 \%$ of the countries at the pre-primary level and $76 \%$ of countries at the primary level. Emphasis on ongoing professional development is also reflected in plans for the development of self-learning tools $147 \%$ in pre-primary and $59 \%$ in primary) and additional resources for training providers to scale up existing programmes focused on digital skills and remote or hybrid teaching ( $40 \%$ in pre-primary and $55 \%$ in primary). Another important measure is the inclusion of remote or hybrid teaching and related ICT skills as part of initial educator preparation programmes $140 \%$ in pre-primary and $66 \%$ in primary). These results are well aligned with the plans for supporting teacher professional learning around the use of digital technology reported in other international surveys covering higher levels of schooling and education $\left(\mathrm{OECD}, 202 \mathrm{l}_{[6]}\right)$. A major opportunity to build teachers' digital competences is with more extensive and innovative uses of online or hybrid teacher professional learning programmes (MineaPic, 2020[23].

However, at both levels only between $20 \%$ and $40 \%$ of countries plan to allocate additional budget to cover training costs or the cost of protected time to release teachers from teaching duties to participate in trainings. Efforts to improve workforce preparation for using digital technologies and distance education may thus come at the expense of professional development in other areas. Countries planning to devote additional resources to cover the costs of protected time for training on distance education at both levels are Japan, Korea, Portugal and Saudi Arabia. Further, only an equally small proportion of countries plan to also reform accountability and quality assurance frameworks to take better account of increased use of remote/hybrid learning for young children. Countries planning reforms in accountability and quality assurance procedures at both levels are the Czech Republic, Estonia, Italy, Korea and Saudi Arabia.

Figure 6.2. Measures to support professional learning for the use of digital technologies and distance education by 2025

Percentage of countries planning system-wide implementation, by level of education

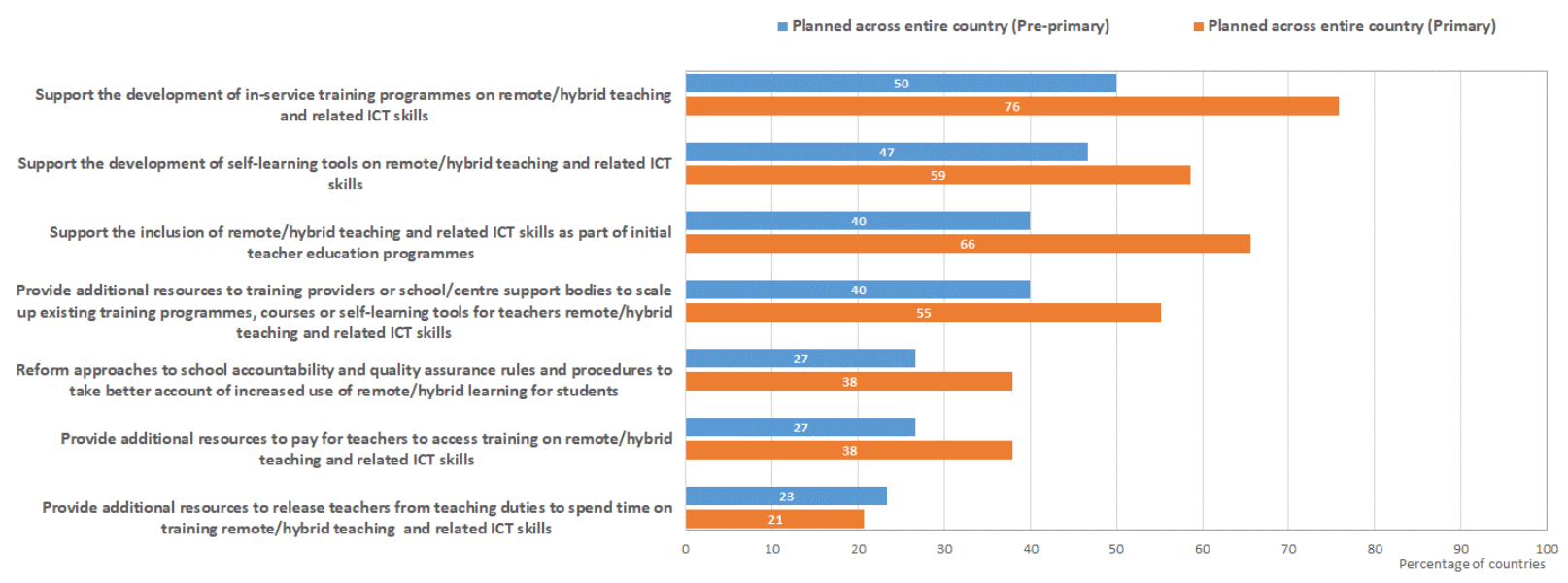

Note: Items are sorted in descending order by the response category "Planned across entire country/jurisdiction" in pre-primary education. Source: OECD Survey on Distance Education for Young Children in 2020. 
Box 6.1. Examples from G20 members: Measures to support professional learning for the use of digital technologies and distance education

In Australia, each state and territory is responsible for making decisions on teacher training in their jurisdictions, including decisions on strategies to support teachers in the use of digital technologies and distance learning. The large number of early childhood education providers adds to the variation in approaches to supporting professional development for early education teachers. Nonetheless, a National Quality Framework supports early childhood education services investing in the professional learning of their staff. All governments across Australia have endorsed the development of a new ten-year National Children's Education and Care Workforce Strategy to support the recruitment, retention, sustainability and quality of the early childhood services workforce. The Strategy is being developed by the Australian Children's Education and Care Quality Authority (ACECQA), together with governments, services and other stakeholders. Public consultations on the strategy closed on 31 May 2021 with feedback informing the final Strategy for consideration by all Education Ministers in late 2021. Among the objectives of the strategy is to respond to impacts from the COVID-19 pandemic, and the Australian Government is examining where and for whom remote and online delivery was effective during school/centre closures, as well as factors impacting success. The insights gained during this period may inform new and innovative ways of using these modes of learning, including teacher professional development and support.

In the United Kingdom, England rolled out an online training course to senior leaders responsible for the quality and delivery of remote education provision. The course supports schools in developing and implementing effective remote education strategies. Schools are also helped to consider how best to target resources towards education recovery and to consider teacher workload, flexible working, and effective working practices. The EdTech Demonstrator programme, a peer support network of schools and colleges expert in their use of technology, will be in place in the academic year 2021-22, offering advice, guidance and training on ways technology can be used to support delivery of the curriculum both inside and outside of the classroom. Training through this programme is available for all teachers and senior leaders in state-funded schools and colleges. And in Wales, a digital learning platform ("Hwb") has been developed with the aim to improve the use of digital technology for teaching and learning in all schools across the country.

In Italy, the new in-service training programmes of the Ministry of Education will aim to extend the experiences promoted during the pandemic to a broader innovation action for Italian schools, with a double focus on better integrating technologies in teaching and learning, and in school organisational practices.

Source: OECD Survey on Distance Education for Young Children in 2020. 


\section{References}

Bao, X. et al. (2020), "Modeling Reading Ability Gain in Kindergarten Children during COVID- 19 School

Closures", International Journal of Environmental Research and Public Health, Vol. 17/17:6371, https://doi.org/10.3390/iierph17176371.

Blaskó, Z., P. da Costa and S. Schnepf (2021), Learning Loss and Educational Inequalities in Europe: Mapping the Potential Consequences of the COVID- 19 Crisis, http://ftp.iza.org/dp 14298.pdf.

Burns, T. and F. Gottschalk (eds.) (2019), Educating 21 st Century Children: Emotional Well-being in the Digital Age, Educational Research and Innovation, OECD Publishing, https://doi.org/10.1787/b7f33425-en.

Engzell, P. et al. (2021), "Learning loss due to school closures during the COVID-1 9 pandemic", Proceedings of the National Academy of Sciences, Vol. $118 / 17$, http://dx.doi.org/10.1073/pnas.20223761 18

European Commission (2019), Digital Education at School in Europe (Eurydice report), Publications Office of the European Union, https://www.uhr.se/globalassets/_uhr.se/internationellt/eurydike/digital-education-atschools-in-europe eurydice-report.pdf (accessed on 3 June 2021).

Gottschalk, F. (2019), "Impacts of technology use on children: Exploring literature on the brain, cognition and well-being", OECD Education Working Paper No. 195, OECD Publishing, Paris, https://doi.org/10.1787/8296464e-en. (accessed on 3 June 2021).

Gutiérrez Bernal, M. et al. (2020), Colombia: Mis Manos te Enseñan (My Hands Teach You), Education continuity stories series, OECD Publishing, Paris., https://oecdedutoday.com/wpcontent/uploads/2020/08/Colombia-Mis-manos-te-ensenan.pdf (accessed on 28 July 2021 ).

Hooft Graafland, J. (2018), "New technologies and 21 st century children: Recent trends and outcomes", OECD Education Working Papers 179, https://doi.org/10.1787/e07la505-en.

Minea-Pic, A. (2020), Innovating teachers' professional learning through digital technologies, OECD Education Working Papers, No. 237, OECD Publishing.

OECD (2021), Recommendation of the Council on Children in the Digital Environment, https://legalinstruments.oecd.org/en/instruments/OECD-LEGAL-0389.

OECD (202 1), Starting Strong VI: Supporting Meaningful Interactions in Early Childhood Education and Care, OECD Publishing, https://doi.org/10.1787/ 447 a06ae-en

OECD (202 1), Supporting young people's mental health through the COVID-19 crisis, OECD Publishing, https://doi.org/10.1787/84e143e5-en.

OECD (202 1), The State of School Education - One year into the COVID pandemic, OECD Publishing, Paris, https://doi.org/10.1787/201dde84-en.

OECD (2020), Flattening the COVID-19 peak: Containment and mitigation policies, https://www.oecdilibrary.org/social-issues-migration-health/flattening-the-covid-19-peak-containment-and-mitigationpolicies e96a4226-en (accessed on 16 June 2021 ). 
OECD (2020), Lessons for Education from COVID-19: A Policy Maker's Handbook for More Resilient Systems, OECD Publishing, Paris, https://dx.doi.org/10.1787/0a530888-en.

OECD (2020), PISA 2018 Results (Volume V): Effective Policies, Successful Schools, PISA, OECD Publishing, Paris, https://dx.doi.org/10.1787/ca768d40-en.

OECD (2020), Strengthening online learning when schools are closed: The role of families and teachers in supporting students during the COVID-19 crisis, https://www.oecd.org/coronavirus/policyresponses/strengthening-online-learning-when-schools-are-closed-the-role-of-families-and-teachers-insupporting-students-during-the-covid-19-crisis-c4ecbabc/ laccessed on 22 June 2021).

OECD (2019), Providing Quality Early Childhood Education and Care: Results from the Starting Strong Survey 2018, TALIS, OECD Publishing, Paris, htpps://dx.doi.org/10.1787/301005dl-en.

Rose, S. et al. (2021), Impact of school closures and subsequent support strategies on attainment and socioemotional wellbeing in Key Stage 1: Interim Paper 1, National Foundation for Educational Research, https://educationendowmentfoundation.org.uk/public/files/Publications/Covid19 Resources/Impact of school closures KS1 interim findings paper - Jan 2021.pdf.

Sepúlveda, A. (2020), The Digital Transformation of Education: Connecting Schools, Empowering Learners, International Telecommunication Union (ITU); UNESCO; UNICEF, https://www.broadbandcommission.org/publication/the-digital-transformation-of-education/laccessed on 3 June 20211 .

Slutsky, R. et al. (2021), "A cross-cultural study on technology use in preschool classrooms: early childhood teacher's preferences, time-use, impact and association with children's play", Early Child Development and Care, Vol. 191/5, pp. 713-725, htpp://dx.doi.org/10.1080/03004430.2019.1645135.

UNESCO (n.d.), Adverse consequences of school closures, https://en.unesco.org/covid19/educationresponse/consequences (accessed on 16 June 2021).

van de Werfhorst, H. (2021), "Inequality in learning is a major concern after school closures", Proceedings of the National Academy of Sciences, Vol. $118 / 20$, p. e2 105243118 , htpp://dx.doi.org/10.1073/pnas.2105243118. 


\section{Annex A. List of tables}

Table A. 1. Prioritisation of development areas/skills when digital technologies used to maintain continuity of education for young children

Based on country reports

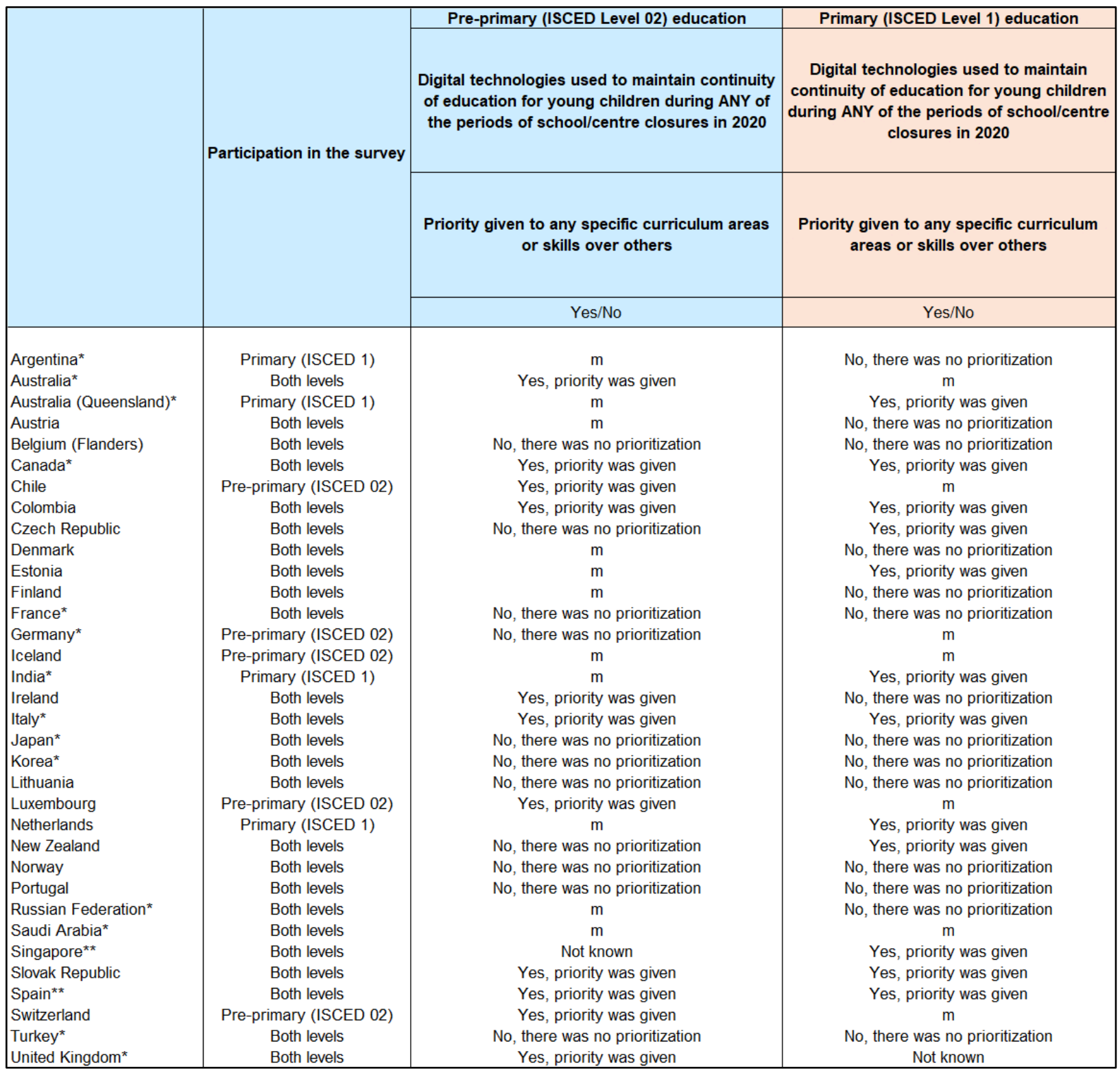

* G20 member countries are indicated with an asterisk.

** G20 guest countries are indicated with a double asterisk.

Note: "m" - Missing information.

Source: OECD Survey on Distance Education for Young Children in 2020. 
Table A.2. [1/2] Continuity of work requirements for centre/school leaders during school/centre closures

Based on country reports

\begin{tabular}{|c|c|c|c|c|c|c|c|c|}
\hline & \multirow[b]{3}{*}{ Participation in the survey } & \multicolumn{7}{|c|}{ Pre-primary (ISCED Level 02) education } \\
\hline & & \multicolumn{7}{|c|}{ FIRST period of 2020 when schools/centres were closed (either fully or partially) in the country/jurisdiction } \\
\hline & & $\begin{array}{c}\text { Yes, in all } \\
\text { schools/cent } \\
\text { res }\end{array}$ & $\begin{array}{c}\text { Yes, in public } \\
\text { schools/cent } \\
\text { res only }\end{array}$ & $\begin{array}{c}\text { Yes, in } \\
\text { private } \\
\text { schools/cent } \\
\text { res only }\end{array}$ & $\begin{array}{c}\text { Yes, teachers in some } \\
\text { geographical areas (e.g. } \\
\text { districts/cities/towns) } \\
\text { only }\end{array}$ & $\begin{array}{c}\text { Yes, for } \\
\text { some age } \\
\text { groups of } \\
\text { children only }\end{array}$ & $\begin{array}{l}\text { Yes, under } \\
\text { other } \\
\text { conditions } \\
\text { (e.g. } \\
\text { vulnerable } \\
\text { groups of } \\
\text { children) }\end{array}$ & $\begin{array}{l}\text { No, there } \\
\text { was no such } \\
\text { requirement }\end{array}$ \\
\hline Argentina* & Primary (ISCED 1) & $\mathrm{m}$ & $\mathrm{m}$ & $\mathrm{m}$ & $\mathrm{m}$ & $\mathrm{m}$ & $\mathrm{m}$ & $\mathrm{m}$ \\
\hline Australia* & Both levels & Yes & $\mathrm{m}$ & $\mathrm{m}$ & $\mathrm{m}$ & $\mathrm{m}$ & $\mathrm{m}$ & $\mathrm{m}$ \\
\hline Australia (Queensland) ${ }^{\star}$ & Primary (ISCED 1) & $\mathrm{m}$ & $\mathrm{m}$ & $\mathrm{m}$ & $\mathrm{m}$ & $\mathrm{m}$ & $\mathrm{m}$ & $\mathrm{m}$ \\
\hline Austria & Both levels & Yes & $\mathrm{m}$ & $\mathrm{m}$ & $\mathrm{m}$ & $\mathrm{m}$ & $\mathrm{m}$ & $\mathrm{m}$ \\
\hline Belgium (Flanders) & Both levels & $\mathrm{m}$ & $\mathrm{m}$ & $\mathrm{m}$ & $\mathrm{m}$ & $\mathrm{m}$ & $\mathrm{m}$ & $\mathrm{m}$ \\
\hline Canada $^{*}$ & Both levels & $\mathrm{m}$ & $\mathrm{m}$ & $\mathrm{m}$ & $\mathrm{m}$ & Yes & $\mathrm{m}$ & $\mathrm{m}$ \\
\hline Chile & Pre-primary (ISCED 02) & Yes & $\mathrm{m}$ & $\mathrm{m}$ & $\mathrm{m}$ & $\mathrm{m}$ & $\mathrm{m}$ & $\mathrm{m}$ \\
\hline Colombia & Both levels & Yes & $\mathrm{m}$ & $\mathrm{m}$ & $\mathrm{m}$ & $\mathrm{m}$ & $\mathrm{m}$ & $\mathrm{m}$ \\
\hline Czech Republic & Both levels & Yes & $\mathrm{m}$ & $\mathrm{m}$ & $\mathrm{m}$ & $\mathrm{m}$ & $\mathrm{m}$ & $\mathrm{m}$ \\
\hline Denmark & Both levels & $\mathrm{m}$ & $\mathrm{m}$ & $\mathrm{m}$ & $\mathrm{m}$ & $\mathrm{m}$ & Yes & $\mathrm{m}$ \\
\hline Estonia & Both levels & $\mathrm{m}$ & $\mathrm{m}$ & $\mathrm{m}$ & $\mathrm{m}$ & $\mathrm{m}$ & $\mathrm{m}$ & $\mathrm{m}$ \\
\hline Finland & Both levels & $\mathrm{m}$ & $\mathrm{m}$ & $\mathrm{m}$ & $\mathrm{m}$ & $\mathrm{m}$ & $\mathrm{m}$ & $\mathrm{m}$ \\
\hline France $^{\star}$ & Both levels & Yes & $\mathrm{m}$ & $\mathrm{m}$ & $\mathrm{m}$ & $\mathrm{m}$ & $\mathrm{m}$ & $\mathrm{m}$ \\
\hline Germany* & Pre-primary (ISCED 02) & $\mathrm{m}$ & $\mathrm{m}$ & $\mathrm{m}$ & $\mathrm{m}$ & $\mathrm{m}$ & $\mathrm{m}$ & Yes \\
\hline Iceland & Pre-primary (ISCED 02) & $\mathrm{m}$ & $\mathrm{m}$ & $\mathrm{m}$ & $\mathrm{m}$ & $\mathrm{m}$ & $\mathrm{m}$ & $\mathrm{m}$ \\
\hline India* & Primary (ISCED 1) & $\mathrm{m}$ & $\mathrm{m}$ & $\mathrm{m}$ & $\mathrm{m}$ & $\mathrm{m}$ & $\mathrm{m}$ & $\mathrm{m}$ \\
\hline Ireland & Both levels & $\mathrm{m}$ & $\mathrm{m}$ & $\mathrm{m}$ & $\mathrm{m}$ & $\mathrm{m}$ & $\mathrm{m}$ & Yes \\
\hline Italy* & Both levels & Yes & $\mathrm{m}$ & $\mathrm{m}$ & $\mathrm{m}$ & $\mathrm{m}$ & $\mathrm{m}$ & $\mathrm{m}$ \\
\hline$J^{\prime}{ }^{2}{ }^{*}$ & Both levels & Yes & $\mathrm{m}$ & $\mathrm{m}$ & $\mathrm{m}$ & $\mathrm{m}$ & $\mathrm{m}$ & $\mathrm{m}$ \\
\hline Korea* ${ }^{*}$ & Both levels & Yes & $\mathrm{m}$ & $\mathrm{m}$ & $\mathrm{m}$ & $\mathrm{m}$ & $\mathrm{m}$ & $\mathrm{m}$ \\
\hline Lithuania & Both levels & Yes & $\mathrm{m}$ & $\mathrm{m}$ & $\mathrm{m}$ & $\mathrm{m}$ & $\mathrm{m}$ & $\mathrm{m}$ \\
\hline Luxembourg & Pre-primary (ISCED 02) & $\mathrm{m}$ & $\mathrm{m}$ & $\mathrm{m}$ & $\mathrm{m}$ & $\mathrm{m}$ & $\mathrm{m}$ & $\mathrm{m}$ \\
\hline Netherlands & Primary (ISCED 1) & $\mathrm{m}$ & $\mathrm{m}$ & $\mathrm{m}$ & $\mathrm{m}$ & $\mathrm{m}$ & $\mathrm{m}$ & $\mathrm{m}$ \\
\hline New Zealand & Both levels & $\mathrm{m}$ & $\mathrm{m}$ & $\mathrm{m}$ & $\mathrm{m}$ & $\mathrm{m}$ & $\mathrm{m}$ & Yes \\
\hline Norway & Both levels & $\mathrm{m}$ & $\mathrm{m}$ & $\mathrm{m}$ & $\mathrm{m}$ & $\mathrm{m}$ & Yes & $\mathrm{m}$ \\
\hline Portugal & Both levels & $\mathrm{m}$ & Yes & $\mathrm{m}$ & $\mathrm{m}$ & $\mathrm{m}$ & $\mathrm{m}$ & $\mathrm{m}$ \\
\hline Russian Federation* & Both levels & Yes & $\mathrm{m}$ & $\mathrm{m}$ & $\mathrm{m}$ & $\mathrm{m}$ & $\mathrm{m}$ & $\mathrm{m}$ \\
\hline Saudi Arabia* & Both levels & $\mathrm{m}$ & $\mathrm{m}$ & $\mathrm{m}$ & $\mathrm{m}$ & $\mathrm{m}$ & $\mathrm{m}$ & $\mathrm{m}$ \\
\hline Singapore ${ }^{\star \star}$ & Both levels & Yes & $\mathrm{m}$ & $\mathrm{m}$ & $\mathrm{m}$ & $\mathrm{m}$ & $\mathrm{m}$ & $\mathrm{m}$ \\
\hline Slovak Republic & Both levels & Yes & $\mathrm{m}$ & $\mathrm{m}$ & $\mathrm{m}$ & $\mathrm{m}$ & $\mathrm{m}$ & $\mathrm{m}$ \\
\hline Spain ${ }^{* \star}$ & Both levels & Yes & Yes & Yes & $\mathrm{m}$ & $\mathrm{m}$ & $\mathrm{m}$ & $\mathrm{m}$ \\
\hline Switzerland & Pre-primary (ISCED 02) & Yes & $\mathrm{m}$ & $\mathrm{m}$ & $\mathrm{m}$ & $\mathrm{m}$ & $\mathrm{m}$ & $\mathrm{m}$ \\
\hline Turkey* & Both levels & $\mathrm{m}$ & $\mathrm{m}$ & $\mathrm{m}$ & $\mathrm{m}$ & $\mathrm{m}$ & $\mathrm{m}$ & Yes \\
\hline United Kingdom & Both levels & Yes & $\mathrm{m}$ & $\mathrm{m}$ & $\mathrm{m}$ & $\mathrm{m}$ & $\mathrm{m}$ & $\mathrm{m}$ \\
\hline
\end{tabular}

* G20 member countries are indicated with an asterisk.

** G20 guest countries are indicated with a double asterisk.

Note: "m" - Missing information.

Source: OECD Survey on Distance Education for Young Children in 2020. 
Table A.2. [2/2] Continuity of work requirements for centre/school leaders during school/centre closures

Based on country reports

\begin{tabular}{|c|c|c|c|c|c|c|c|c|}
\hline & & & & Prim & ary (ISCED Level 1) educ & ation & & \\
\hline & & FIRST perio & of 2020 when & n schools/centr & res were closed (either fu & lly or partially) & the country & jurisdiction \\
\hline & Participation in the survey & $\begin{array}{c}\text { Yes, in all } \\
\text { schools/cent } \\
\text { res }\end{array}$ & $\begin{array}{c}\text { Yes, in public } \\
\text { schools/cent } \\
\text { res only }\end{array}$ & $\begin{array}{c}\text { Yes, in } \\
\text { private } \\
\text { schools/cent } \\
\text { res only }\end{array}$ & $\begin{array}{l}\text { Yes, teachers in some } \\
\text { geographical areas (e.g. } \\
\text { districts/cities/towns) } \\
\text { only }\end{array}$ & $\begin{array}{c}\text { Yes, for } \\
\text { some age } \\
\text { groups of } \\
\text { children only }\end{array}$ & $\begin{array}{l}\text { Yes, under } \\
\text { other } \\
\text { conditions } \\
\text { (e.g. } \\
\text { vulnerable } \\
\text { groups of } \\
\text { children) }\end{array}$ & $\begin{array}{l}\text { No, there } \\
\text { was no such } \\
\text { requirement }\end{array}$ \\
\hline Argentina* & Primary (ISCED 1) & Yes & $\mathrm{m}$ & $\mathrm{m}$ & $\mathrm{m}$ & $\mathrm{m}$ & $\mathrm{m}$ & $\mathrm{m}$ \\
\hline Australia* & Both levels & $\mathrm{m}$ & $\mathrm{m}$ & m & m & $\mathrm{m}$ & m & $\mathrm{m}$ \\
\hline Australia (Queensland)* & Primary (ISCED 1) & $\mathrm{m}$ & Yes & $\mathrm{m}$ & $\mathrm{m}$ & $\mathrm{m}$ & $\mathrm{m}$ & $\mathrm{m}$ \\
\hline Austria & Both levels & Yes & $\mathrm{m}$ & $\mathrm{m}$ & $\mathrm{m}$ & $\mathrm{m}$ & $\mathrm{m}$ & $\mathrm{m}$ \\
\hline Belgium (Flanders) & Both levels & $\mathrm{m}$ & $\mathrm{m}$ & $\mathrm{m}$ & $\mathrm{m}$ & $\mathrm{m}$ & $\mathrm{m}$ & $\mathrm{m}$ \\
\hline Canada* & Both levels & Yes & $\mathrm{m}$ & $\mathrm{m}$ & $\mathrm{m}$ & $\mathrm{m}$ & $\mathrm{m}$ & $\mathrm{m}$ \\
\hline Chile & Pre-primary (ISCED 02) & $\mathrm{m}$ & $\mathrm{m}$ & $\mathrm{m}$ & $\mathrm{m}$ & $\mathrm{m}$ & $\mathrm{m}$ & $\mathrm{m}$ \\
\hline Colombia & Both levels & Yes & $\mathrm{m}$ & $\mathrm{m}$ & $\mathrm{m}$ & $\mathrm{m}$ & $\mathrm{m}$ & $\mathrm{m}$ \\
\hline Czech Republic & Both levels & Yes & $\mathrm{m}$ & $\mathrm{m}$ & $\mathrm{m}$ & $\mathrm{m}$ & $\mathrm{m}$ & $\mathrm{m}$ \\
\hline Denmark & Both levels & Yes & $\mathrm{m}$ & $\mathrm{m}$ & $\mathrm{m}$ & $\mathrm{m}$ & $\mathrm{m}$ & $\mathrm{m}$ \\
\hline Estonia & Both levels & Yes & $\mathrm{m}$ & $\mathrm{m}$ & $\mathrm{m}$ & $\mathrm{m}$ & $\mathrm{m}$ & $\mathrm{m}$ \\
\hline Finland & Both levels & Yes & $\mathrm{m}$ & $\mathrm{m}$ & $\mathrm{m}$ & $\mathrm{m}$ & $\mathrm{m}$ & $\mathrm{m}$ \\
\hline France ${ }^{*}$ & Both levels & Yes & $\mathrm{m}$ & $\mathrm{m}$ & $\mathrm{m}$ & $\mathrm{m}$ & $\mathrm{m}$ & $\mathrm{m}$ \\
\hline Germany* & Pre-primary (ISCED 02) & $\mathrm{m}$ & $\mathrm{m}$ & $\mathrm{m}$ & $\mathrm{m}$ & $\mathrm{m}$ & $\mathrm{m}$ & $\mathrm{m}$ \\
\hline Iceland & Pre-primary (ISCED 02) & $\mathrm{m}$ & $\mathrm{m}$ & $\mathrm{m}$ & $\mathrm{m}$ & $\mathrm{m}$ & $\mathrm{m}$ & $\mathrm{m}$ \\
\hline India* ${ }^{*}$ & Primary (ISCED 1) & Yes & $\mathrm{m}$ & $\mathrm{m}$ & $\mathrm{m}$ & $\mathrm{m}$ & $\mathrm{m}$ & $\mathrm{m}$ \\
\hline Ireland & Both levels & $\mathrm{m}$ & Yes & $\mathrm{m}$ & $\mathrm{m}$ & $\mathrm{m}$ & $\mathrm{m}$ & $\mathrm{m}$ \\
\hline Italy* & Both levels & Yes & $\mathrm{m}$ & $\mathrm{m}$ & $\mathrm{m}$ & $\mathrm{m}$ & $\mathrm{m}$ & $\mathrm{m}$ \\
\hline Japan* & Both levels & Yes & $\mathrm{m}$ & $\mathrm{m}$ & $\mathrm{m}$ & $\mathrm{m}$ & $\mathrm{m}$ & $\mathrm{m}$ \\
\hline Korea* & Both levels & Yes & $\mathrm{m}$ & m & $\mathrm{m}$ & $\mathrm{m}$ & $\mathrm{m}$ & $\mathrm{m}$ \\
\hline Lithuania & Both levels & Yes & $\mathrm{m}$ & $\mathrm{m}$ & $\mathrm{m}$ & $\mathrm{m}$ & $\mathrm{m}$ & $\mathrm{m}$ \\
\hline Luxembourg & Pre-primary (ISCED 02) & $\mathrm{m}$ & $\mathrm{m}$ & $\mathrm{m}$ & $\mathrm{m}$ & $\mathrm{m}$ & $\mathrm{m}$ & $\mathrm{m}$ \\
\hline Netherlands & Primary (ISCED 1) & Yes & $\mathrm{m}$ & $\mathrm{m}$ & $\mathrm{m}$ & $\mathrm{m}$ & $\mathrm{m}$ & $\mathrm{m}$ \\
\hline New Zealand & Both levels & Yes & $\mathrm{m}$ & $\mathrm{m}$ & $\mathrm{m}$ & $\mathrm{m}$ & $\mathrm{m}$ & $\mathrm{m}$ \\
\hline Norway & Both levels & Yes & $\mathrm{m}$ & $\mathrm{m}$ & $\mathrm{m}$ & $\mathrm{m}$ & $\mathrm{m}$ & $\mathrm{m}$ \\
\hline Portugal & Both levels & $\mathrm{m}$ & Yes & $\mathrm{m}$ & $\mathrm{m}$ & $\mathrm{m}$ & $\mathrm{m}$ & $\mathrm{m}$ \\
\hline Russian Federation* ${ }^{*}$ & Both levels & Yes & $\mathrm{m}$ & $\mathrm{m}$ & $\mathrm{m}$ & $\mathrm{m}$ & $\mathrm{m}$ & $\mathrm{m}$ \\
\hline Saudi Arabia ${ }^{*}$ & Both levels & $\mathrm{m}$ & $\mathrm{m}$ & $\mathrm{m}$ & $\mathrm{m}$ & $\mathrm{m}$ & $\mathrm{m}$ & $\mathrm{m}$ \\
\hline Singapore ${ }^{\star \star}$ & Both levels & $\mathrm{m}$ & Yes & $\mathrm{m}$ & $\mathrm{m}$ & $\mathrm{m}$ & $\mathrm{m}$ & $\mathrm{m}$ \\
\hline Slovak Republic & Both levels & Yes & $\mathrm{m}$ & $\mathrm{m}$ & $\mathrm{m}$ & $\mathrm{m}$ & $\mathrm{m}$ & $\mathrm{m}$ \\
\hline Spain $^{\star *}$ & Both levels & Yes & Yes & Yes & $\mathrm{m}$ & $\mathrm{m}$ & $\mathrm{m}$ & $\mathrm{m}$ \\
\hline Switzerland & Pre-primary (ISCED 02) & $\mathrm{m}$ & $\mathrm{m}$ & $\mathrm{m}$ & $\mathrm{m}$ & $\mathrm{m}$ & $\mathrm{m}$ & $\mathrm{m}$ \\
\hline Turkey ${ }^{*}$ & $\begin{array}{l}\text { Both levels } \\
\text { But }\end{array}$ & Yes & $\mathrm{m}$ & $\mathrm{m}$ & $\mathrm{m}$ & $\mathrm{m}$ & $\mathrm{m}$ & $\mathrm{m}$ \\
\hline United Kingdom* ${ }^{*}$ & Both levels & $\mathrm{m}$ & $\mathrm{m}$ & $\mathrm{m}$ & $\mathrm{m}$ & $\mathrm{m}$ & Yes & $\mathrm{m}$ \\
\hline
\end{tabular}

* G20 member countries are indicated with an asterisk.

** G20 guest countries are indicated with a double asterisk.

Note: "m" - Missing information.

Source: OECD Survey on Distance Education for Young Children in 2020. 
Table A.3. [1/2] Use of broadcast technologies to maintain continuity of education for young children

Based on country reports

\begin{tabular}{|c|c|c|c|c|}
\hline & \multirow{4}{*}{ Participation in the survey } & \multicolumn{3}{|c|}{ Pre-primary (ISCED Level 02) education } \\
\hline & & \multicolumn{3}{|c|}{ During the FIRST period of $\mathbf{2 0 2 0}$ when schools/centres were closed (either fully or partially) } \\
\hline & & $\begin{array}{l}\text { Broadcast technologies (e.g. television, } \\
\text { radio) used to maintain continuity of } \\
\text { education for young children }\end{array}$ & $\begin{array}{c}\text { Primarly responsible for the creation of the } \\
\text { content offered through broadcat } \\
\text { technologies }\end{array}$ & $\begin{array}{l}\text { Priority given to any specific curriculum } \\
\text { areas or skills over others when broadcast } \\
\text { technologies used to maintain continuity of } \\
\text { education for young children }\end{array}$ \\
\hline & & Yes/No & Responsible & Yes/No \\
\hline Argentina* & Primary (ISCED 1) & $\mathrm{m}$ & $\mathrm{m}$ & $\mathrm{m}$ \\
\hline Australia* & Both levels & Yes, as a complement to digital technologies & Other & Not known \\
\hline Australia (Queensland)* & Primary (ISCED 1) & 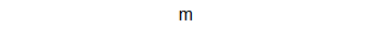 & $\mathrm{m}$ & m \\
\hline Austria & Both levels & Yes, as a complement to digital technologies & $\mathrm{m}$ & Not known \\
\hline Belgium (Flanders) & Both levels & Yes, as a complement to digital technologies & Schools/centres and/or teachers & No, there was no prioritization \\
\hline Canada $^{*}$ & Both levels & Yes, as a complement to digital technologies & Ministry of Education or education authorities & No, there was no prioritization \\
\hline Chile & Pre-primary (ISCED 02) & Yes, as a complement to digital technologies & Ministry of Education or education authorities & Yes, priority was given \\
\hline Colombia & Both levels & Yes, as a complement to digital technologies & Ministry of Education or education authorities & Yes, priority was given \\
\hline Czech Republic & Both levels & No, not at all & $\mathrm{m}$ & $\mathrm{m}$ \\
\hline Denmark & Both levels & Yes, as a complement to digital technologies & Other & Not known \\
\hline Estonia & Both levels & $\mathrm{m}$ & $\mathrm{m}$ & m \\
\hline Finland & Both levels & $\mathrm{m}$ & $\mathrm{m}$ & $\mathrm{m}$ \\
\hline France $^{*}$ & Both levels & Yes, as a complement to digital technologies & Schools/centres and/or teachers & No, there was no prioritization \\
\hline Germany* & Pre-primary (ISCED 02) & Yes, as a complement to digital technologies & Other & Not known \\
\hline Iceland & Pre-primary (ISCED 02) & $\mathrm{m}$ & $\mathrm{m}$ & $\mathrm{m}$ \\
\hline India ${ }^{*}$ & Primary (ISCED 1) & $\mathrm{m}$ & $\mathrm{m}$ & $\mathrm{m}$ \\
\hline Ireland & Both levels & Yes, as a complement to digital technologies & Other & Yes, priority was given \\
\hline Italy ${ }^{\star}$ & Both levels & Yes, as a complement to digital technologies & Ministry of Education or education authorities & Yes, priority was given \\
\hline $\operatorname{Japan}^{\star}$ & Both levels & No, not at all & $\mathrm{m}$ & $\mathrm{m}$ \\
\hline Korea* ${ }^{*}$ & Both levels & Yes, as a complement to digital technologies & Other & No, there was no prioritization \\
\hline Lithuania & Both levels & Yes, as a complement to digital technologies & Schools/centres and/or teachers & No, there was no prioritization \\
\hline Luxembourg & Pre-primary (ISCED 02) & No, not at all & $\mathrm{m}$ & m \\
\hline Netherlands & Primary (ISCED 1) & $\mathrm{m}$ & $\mathrm{m}$ & $\mathrm{m}$ \\
\hline New Zealand & Both levels & Yes, as a complement to digital technologies & Other & No, there was no prioritization \\
\hline Norway & Both levels & No, not at all & $\mathrm{m}$ & $\mathrm{m}$ \\
\hline Portugal & Both levels & Yes, as a complement to digital technologies & Other & No, there was no prioritization \\
\hline Russian Federation* & Both levels & No, not at all & $\mathrm{m}$ & $\mathrm{m}$ \\
\hline Saudi Arabia* ${ }^{*}$ & Both levels & $\mathrm{m}$ & $\mathrm{m}$ & $\mathrm{m}$ \\
\hline Singapore ${ }^{\star \star}$ & Both levels & No, not at all & $\mathrm{m}$ & $\mathrm{m}$ \\
\hline Slovak Republic & Both levels & Yes, as a complement to digital technologies & Outsourced to third party & No, there was no prioritization \\
\hline Spain ${ }^{\star \star}$ & Both levels & Yes, as a complement to digital technologies & Ministry of Education or education authorities & Yes, priority was given \\
\hline Switzerland & Pre-primary (ISCED 02) & Yes, as a complement to digital technologies & Schools/centres and/or teachers & Yes, priority was given \\
\hline Turkey* & Both levels & Yes, as a complement to digital technologies & Ministry of Education or education authorities & No, there was no prioritization \\
\hline United Kingdom* ${ }^{*}$ & Both levels & Yes, in place of digital technologies & Other & Not known \\
\hline
\end{tabular}

* G20 member countries are indicated with an asterisk.

* G20 guest countries are indicated with a double asterisk.

Note: "m" - Missing information.

Source: OECD Survey on Distance Education for Young Children in 2020. 
Table A.3. [2/2] Use of broadcast technologies to maintain continuity of education for young children

Based on country reports

\begin{tabular}{|c|c|c|c|c|}
\hline & & & Primary (ISCED Level 1) education & \\
\hline & & During the FIRST peric & d of 2020 when schools/centres were closed & (either fully or partially) \\
\hline & Participation in the survey & $\begin{array}{l}\text { Broadcast technologies (e.g. television, } \\
\text { radio) used to maintain continuity of } \\
\text { education for young children }\end{array}$ & $\begin{array}{l}\text { Primarly responsible for the creation of the } \\
\text { content offered through broadcat } \\
\text { technologies }\end{array}$ & $\begin{array}{l}\text { Priority given to any specific curriculum } \\
\text { areas or skills over others when broadcast } \\
\text { technologies used to maintain continuity of } \\
\text { education for young children }\end{array}$ \\
\hline & & Yes/No & Responsible & Yes/No \\
\hline Argentina* & Primary (ISCED 1) & Yes, as a complement to digital technologies & Ministry of Education or education authorities & No, there was no prioritization \\
\hline Australia** & Both levels & Yes, as a complement to digital technologies & $\mathrm{m}$ & Yes, priority was given \\
\hline Australia (Queensland) ${ }^{*}$ & Primary (ISCED 1) & Yes, as a complement to digital technologies & Ministry of Education or education authorities & Yes, priority was given \\
\hline Austria & Both levels & No, not at all & $\mathrm{m}$ & $\mathrm{m}$ \\
\hline Belgium (Flanders) & Both levels & Yes, as a complement to digital technologies & Schools/centres and/or teachers & Yes, priority was given \\
\hline Canada $^{*}$ & Both levels & Yes, as a complement to digital technologies & Ministry of Education or education authorities & Yes, priority was given \\
\hline Chile & Pre-primary (ISCED 02) & $\mathrm{m}$ & $\mathrm{m}$ & $\mathrm{m}$ \\
\hline Colombia & Both levels & Yes, as a complement to digital technologies & Ministry of Education or education authorities & Yes, priority was given \\
\hline Czech Republic & Both levels & Yes, as a complement to digital technologies & Schools/centres and/or teachers & Yes, priority was given \\
\hline Denmark & Both levels & No, not at all & $\mathrm{m}$ & $\mathrm{m}$ \\
\hline Estonia & Both levels & Yes, as a complement to digital technologies & Ministry of Education or education authorities & Yes, priority was given \\
\hline Finland & Both levels & No, not at all & 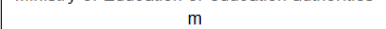 & $\mathrm{m}$ \\
\hline France $^{*}$ & Both levels & Yes, as a complement to digital technologies & Outsourced to third party & No, there was no prioritization \\
\hline Germany* & Pre-primary (ISCED 02) & $\mathrm{m}$ & $\mathrm{m}$ & $\mathrm{m}$ \\
\hline land & Pre-primary (ISCED 02) & $\mathrm{m}$ & $\mathrm{m}$ & $\mathrm{m}$ \\
\hline India* & Primary (ISCED 1) & Yes, as a complement to digital technologies & Ministry of Education or education authorities & Yes, priority was given \\
\hline Ireland & Both levels & Yes, as a complement to digital technologies & Schools/centres and/or teachers & No, there was no prioritization \\
\hline Italy* ${ }^{*}$ & Both levels & Yes, as a complement to digital technologies & Other & Yes, priority was given \\
\hline Japan $^{*}$ & Both levels & Yes, in place of digital technologies & Other & No, there was no prioritization \\
\hline Korea* ${ }^{*}$ & Both levels & Yes, as a complement to digital technologies & Other & No, there was no prioritization \\
\hline Lithuania & Both levels & Yes, as a complement to digital technologies & Schools/centres and/or teachers & No, there was no prioritization \\
\hline Luxembourg & Pre-primary (ISCED 02) & $\mathrm{m}$ & $\mathrm{m}$ & $\mathrm{m}$ \\
\hline Netherlands & Primary (ISCED 1) & No, not at all & $\mathrm{m}$ & $\mathrm{m}$ \\
\hline New Zealand & Both levels & Yes, as a complement to digital technologies & Ministry of Education or education authorities & Yes, priority was given \\
\hline Norway & Both levels & No, not at all & $\mathrm{m}$ & $\mathrm{m}$ \\
\hline Portugal & Both levels & Yes, as a complement to digital technologies & Ministry of Education or education authorities & No, there was no prioritization \\
\hline Russian Federation* & Both levels & No, not at all & $\mathrm{m}$ & $\mathrm{m}$ \\
\hline Saudi Arabia* & Both levels & $\mathrm{m}$ & $\mathrm{m}$ & $\mathrm{m}$ \\
\hline Singapore ${ }^{\star \star}$ & Both levels & No, not at all & $\mathrm{m}$ & $\mathrm{m}$ \\
\hline Slovak Republic & Both levels & Yes, as a complement to digital technologies & Ministry of Education or education authorities & Yes, priority was given \\
\hline $\begin{array}{l}\text { Spain } \\
\text { Switzer } \\
\text { Swand }\end{array}$ & $\begin{array}{l}\text { Both levels } \\
\text { D-primary ISCEL }\end{array}$ & Yes, as a complement to digital technologies & Ministry of Education or education authorities & Yes, priority was given \\
\hline $\begin{array}{l}\text { Switzerland } \\
\text { Turkey }^{\star}\end{array}$ & $\begin{array}{l}\text { re-primary (ISCED 02) } \\
\text { Both levels }\end{array}$ & Yes, as a complement to digital technologies & Ministry of Education or education authorities & $\begin{array}{c}\mathrm{m} \\
\text { Yes, priority was given }\end{array}$ \\
\hline United Kingdom* & Both levels & Yes, as a complement to digital technologies & (1) & Not known \\
\hline
\end{tabular}

* G20 member countries are indicated with an asterisk.

** G20 guest countries are indicated with a double asterisk.

Note: "m" - Missing information.

Source: OECD Survey on Distance Education for Young Children in 2020. 
Table A.4. [1/4] Reasons for difficulties to maintain continuity of education for groups of young children

Based on country reports

\begin{tabular}{|c|c|c|c|c|c|c|c|c|c|c|c|c|c|}
\hline & \multirow{4}{*}{ Participation in the survey } & \multicolumn{12}{|c|}{ Pre-primary (ISCED Level 02) education } \\
\hline & & \multicolumn{4}{|c|}{ Children from socio-economically disadvantaged homes } & \multicolumn{4}{|c|}{$\begin{array}{l}\text { Children whose first language is different from the language } \\
\text { used in the centre/school }\end{array}$} & \multicolumn{4}{|c|}{$\begin{array}{l}\text { Children with special educational needs (children who are } \\
\text { cognitively, physically or emotionally disadvantaged) }\end{array}$} \\
\hline & & $\begin{array}{l}\text { Lack of } \\
\text { infrastructure } \\
\text { (e.g. internet, } \\
\text { tablet, } \\
\text { computer) in } \\
\text { children's } \\
\text { homes }\end{array}$ & $\begin{array}{c}\text { Lack of } \\
\text { infrastructure } \\
\text { (e.g. internet, } \\
\text { tablet, } \\
\text { computer) for } \\
\text { teachers }\end{array}$ & $\begin{array}{c}\text { Inadequateness of } \\
\text { digital learning } \\
\text { technologies and } \\
\text { materials for this } \\
\text { group of children }\end{array}$ & $\begin{array}{c}\text { Limited } \\
\text { availability or } \\
\text { capability of } \\
\text { parents/caregi } \\
\text { vers to } \\
\text { support } \\
\text { distance } \\
\text { education for } \\
\text { this group of } \\
\text { children }\end{array}$ & $\begin{array}{l}\text { Lack of } \\
\text { infrastructure } \\
\text { (e.g. internet, } \\
\text { tablet, } \\
\text { computer) in } \\
\text { children's } \\
\text { homes }\end{array}$ & $\begin{array}{c}\text { Lack of } \\
\text { infrastructure } \\
\text { (e.g. internet, } \\
\text { tablet, } \\
\text { computer) for } \\
\text { teachers }\end{array}$ & $\begin{array}{l}\text { Inadequatenes } \\
\text { s of digital } \\
\text { learning } \\
\text { technologies } \\
\text { and materials } \\
\text { for this group } \\
\text { of children }\end{array}$ & $\begin{array}{c}\text { Limited } \\
\text { availability or } \\
\text { capability of } \\
\text { parents/caregi } \\
\text { vers to } \\
\text { support } \\
\text { distance } \\
\text { education for } \\
\text { this group of } \\
\text { children }\end{array}$ & $\begin{array}{l}\text { Lack of } \\
\text { infrastructure } \\
\text { (e.g. internet, } \\
\text { tablet, } \\
\text { computer) in } \\
\text { children's } \\
\text { homes }\end{array}$ & $\begin{array}{c}\text { Lack of } \\
\text { infrastructure } \\
\text { (e.g. internet, } \\
\text { tablet, } \\
\text { computer) for } \\
\text { teachers }\end{array}$ & $\begin{array}{c}\text { Inadequatenes } \\
\text { s of digital } \\
\text { learning } \\
\text { technologies } \\
\text { and materials } \\
\text { for this group } \\
\text { of children }\end{array}$ & \begin{tabular}{|c|} 
Limited \\
availability or \\
capability of \\
parents/caregi \\
vers to \\
support \\
distance \\
education for \\
this group of \\
children
\end{tabular} \\
\hline & & Yes/No & Yes/No & Yes/No & Yes/No & Yes/No & Yes/No & Yes/No & Yes/No & Yes/No & Yes/No & Yes/No & Yes/No \\
\hline Argentina ${ }^{*}$ & Primary (ISCED 1) & $\mathrm{m}$ & $\mathrm{m}$ & $\mathrm{m}$ & $\mathrm{m}$ & $\mathrm{m}$ & $\mathrm{m}$ & $\mathrm{m}$ & $\mathrm{m}$ & $\mathrm{m}$ & $\mathrm{m}$ & $\mathrm{m}$ & $\mathrm{m}$ \\
\hline 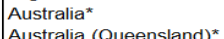 & $\begin{array}{l}\text { Both levels } \\
\text { Primar (SCED 1) }\end{array}$ & Yes & No & No & Yes & $\mathrm{m}$ & $\mathrm{m}$ & $\mathrm{m}$ & $\mathrm{m}$ & Yes & No & No & No \\
\hline $\begin{array}{l}\text { AAstralia (Queensland) } \\
\text { Austria }\end{array}$ & $\begin{array}{l}\text { Primary (ISCED 1) } \\
\text { Both levels }\end{array}$ & 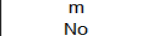 & $\begin{array}{l}\mathrm{m} \\
\text { No }\end{array}$ & $\begin{array}{l}\mathrm{m} \\
\text { No }\end{array}$ & $\begin{array}{l}m \\
\text { No }\end{array}$ & $\underset{m}{m}$ & $\underset{\mathrm{m}}{\mathrm{m}}$ & $\underset{m}{m}$ & $\underset{m}{m}$ & $\begin{array}{l}m \\
\text { No }\end{array}$ & $\begin{array}{l}m \\
\text { No }\end{array}$ & $\begin{array}{l}m \\
\text { No }\end{array}$ & $\begin{array}{l}m \\
\text { No }\end{array}$ \\
\hline Belgium (Flanders) & Both levels & Yes & No & No & Yes & $\mathrm{m}$ & $\mathrm{m}$ & $\mathrm{m}$ & $\mathrm{m}$ & No & No & $\begin{array}{l}\text { No } \\
\text { Yes }\end{array}$ & $\begin{array}{l}\text { Nos } \\
\text { Yes }\end{array}$ \\
\hline Canada* $_{\text {Chile }}$ & & Yes & No & No & & No & No & Yes & Yes & No & Yes & Yes & No \\
\hline $\begin{array}{l}\text { Chile } \\
\text { Colombia }\end{array}$ & $\begin{array}{l}\text { Pre-primary (ISCED 02) } \\
\text { Both levels }\end{array}$ & $\begin{array}{l}\text { Yes } \\
\text { Yes }\end{array}$ & $\begin{array}{l}\text { Yes } \\
\text { Yes }\end{array}$ & $\begin{array}{l}\text { No } \\
\text { Yes }\end{array}$ & $\begin{array}{l}\text { Yes } \\
\text { YYs }\end{array}$ & $\mathrm{m}$ & $\mathrm{m}$ & $\mathrm{m}$ & $\mathrm{m}$ & $\begin{array}{r}\text { Yes } \\
\text { Yes }\end{array}$ & $\begin{array}{l}\text { Yes } \\
\text { Yos }\end{array}$ & $\begin{array}{l}\text { Yes } \\
\text { Yyes }\end{array}$ & Yes \\
\hline $\begin{array}{l}\text { Colambia } \\
\text { Czech Republic }\end{array}$ & $\begin{array}{l}\text { Both le } \\
\text { Both le: }\end{array}$ & $\begin{array}{l}\text { Pres } \\
\text { res }\end{array}$ & $\begin{array}{l}\text { Nes } \\
\text { No }\end{array}$ & $\begin{array}{l}\text { Nes } \\
\text { No }\end{array}$ & $\begin{array}{l}\text { Yes } \\
\text { Yes }\end{array}$ & $\underset{m}{m}$ & $\underset{\mathrm{m}}{\mathrm{m}}$ & $\underset{m}{m}$ & $\underset{\mathrm{m}}{\mathrm{m}}$ & $\begin{array}{l}\text { Yes } \\
\text { res }\end{array}$ & $\begin{array}{l}\text { Yes } \\
\text { no }\end{array}$ & $\begin{array}{l}\text { Yes } \\
\text { Yes }\end{array}$ & $\begin{array}{l}\text { Yes } \\
\text { Yes }\end{array}$ \\
\hline $\begin{array}{l}\text { Denmark } \\
\text { Dention }\end{array}$ & $\begin{array}{l}\text { Boun evers } \\
\text { Both levels }\end{array}$ & $\mathrm{m}$ & $\mathrm{m}$ & $\mathrm{m}$ & $\begin{array}{l}\text { res } \\
\mathrm{m}\end{array}$ & m & $\mathrm{m}$ & m & $\mathrm{m}$ & m & $\mathrm{m}$ & m & $\begin{array}{r}\text { Yes } \\
\text { m }\end{array}$ \\
\hline $\begin{array}{l}\text { Dentmakr } \\
\text { Estonia }\end{array}$ & Both levels & $\mathrm{m}$ & $\mathrm{m}$ & $\mathrm{m}$ & $\mathrm{m}$ & $\mathrm{m}$ & $\mathrm{m}$ & $\mathrm{m}$ & $\mathrm{m}$ & m & m & m & m \\
\hline Finland & Both lev & $\mathrm{m}$ & $\mathrm{m}$ & $\mathrm{m}$ & $\mathrm{m}$ & $\mathrm{m}$ & $\mathrm{m}$ & $\mathrm{m}$ & $\mathrm{m}$ & $\mathrm{m}$ & $\mathrm{m}$ & $\mathrm{m}$ & $\mathrm{m}$ \\
\hline France ${ }^{*}$ & Both leve & Yes & No & No & No & $\mathrm{m}$ & $\mathrm{m}$ & $\mathrm{m}$ & $\mathrm{m}$ & No & No & Yes & No \\
\hline $\begin{array}{l}\text { Germany }{ }^{*} \\
\text { Icelalnd }\end{array}$ & $\begin{array}{l}\text { Pre-primary (ISCED 02) } \\
\text { Pre-primang (ISCED 0?) }\end{array}$ & $\begin{array}{c}\text { Yes } \\
\mathrm{m}\end{array}$ & $\begin{array}{c}\text { No } \\
m\end{array}$ & 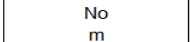 & $\begin{array}{c}\text { Yes } \\
\mathrm{m}\end{array}$ & $m$ & $\mathrm{~m}$ & $m$ & $\mathrm{~m}$ & No & $\begin{array}{c}\text { No } \\
\mathrm{m}\end{array}$ & No & No \\
\hline 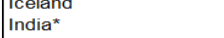 & $\begin{array}{l}\text { Preprimary (ISCED 02) } \\
\text { Primary (ISCED 1) }\end{array}$ & $\underset{m}{m}$ & $\underset{m}{m}$ & $\begin{array}{l}\mathrm{m} \\
\mathrm{m}\end{array}$ & $\underset{m}{m}$ & 蛧 & $\mathrm{m}$ & $\mathrm{m}$ & $\frac{m}{m}$ & $\mathrm{~m}$ & $\mathrm{~m}$ & $\mathrm{~m}$ & $\frac{m}{m}$ \\
\hline | & Both levels & Yes & No & No & Yes & $\mathrm{m}$ & $\mathrm{m}$ & $\mathrm{m}$ & $\mathrm{m}$ & No & No & Yes & Yes \\
\hline Italy* & $\begin{array}{l}\text { Both levels } \\
\text { Buth }\end{array}$ & Yes & $\begin{array}{c}\text { No } \\
\mathrm{m}\end{array}$ & No & Yes & $\mathrm{m}$ & $\mathrm{m}$ & $\mathrm{m}$ & $\mathrm{m}$ & Yes & No & Yes & No \\
\hline 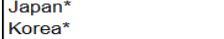 & $\begin{array}{l}\text { Doth hevels } \\
\text { Both levels }\end{array}$ & Yes & $\begin{array}{l}\mathrm{m} \\
\text { No }\end{array}$ & $\begin{array}{l}\mathrm{m} \\
\text { No }\end{array}$ & Yes & 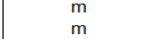 & $\begin{array}{c}\mathrm{m} \\
\mathrm{m}\end{array}$ & $\underset{m}{m}$ & $\underset{m}{m}$ & $\begin{array}{l}\mathrm{m} \\
\text { No }\end{array}$ & $\begin{array}{l}\mathrm{m} \\
\text { No }\end{array}$ & $\begin{array}{c}\text { mes } \\
\text { Yes }\end{array}$ & $\begin{array}{l}\mathrm{m} \\
\text { Yes }\end{array}$ \\
\hline Lithuania & Both levels & Yes & Yes & Yes & Yes & $\mathrm{m}$ & $\mathrm{m}$ & $\mathrm{m}$ & $\mathrm{m}$ & Yes & Yes & Yes & Yes \\
\hline Luxembourg & Pre-primary (ISCED 02) & $\begin{array}{r}\text { Yes } \\
\mathrm{m}\end{array}$ & No & $\begin{array}{c}\text { Yes } \\
\mathrm{m}\end{array}$ & Yes & $\mathrm{m}$ & $\mathrm{m}$ & $\mathrm{m}$ & $\mathrm{m}$ & Yes & No & Yes & Yes \\
\hline $\mid \begin{array}{l}\text { Netherlands } \\
\text { New Zealand }\end{array}$ & $\begin{array}{l}\text { Primary (ISCED 1) } \\
\text { Both levels }\end{array}$ & $\begin{array}{l}\mathrm{m} \\
\mathrm{m}\end{array}$ & $\begin{array}{l}\mathrm{m} \\
\mathrm{m}\end{array}$ & $\underset{m}{m}$ & $\underset{\mathrm{m}}{\mathrm{m}}$ & $\begin{array}{c}m \\
m\end{array}$ & $\underset{m}{m}$ & $\underset{m}{m}$ & $\underset{m}{m}$ & $\underset{m}{m}$ & 蛧 & $\underset{m}{m}$ & 泾 \\
\hline Norway & Both levels & m & $\mathrm{m}$ & $\mathrm{m}$ & $\mathrm{m}$ & m & $\mathrm{m}$ & $\mathrm{m}$ & $\mathrm{m}$ & $\mathrm{m}$ & & $\mathrm{m}$ & $\mathrm{m}$ \\
\hline $\mid \begin{array}{l}\text { Portugal } \\
\text { Russian Federation }\end{array}$ & $\begin{array}{l}\text { Both levels } \\
\text { Both levels }\end{array}$ & $\begin{array}{c}\text { Yes } \\
\text { m }\end{array}$ & $\begin{array}{c}\text { No } \\
\mathrm{m}\end{array}$ & $\begin{array}{c}\text { No } \\
\mathrm{m}\end{array}$ & $\begin{array}{c}\text { No } \\
\mathrm{m}\end{array}$ & $\underset{m}{m}$ & $\underset{\mathrm{m}}{\mathrm{m}}$ & $\underset{m}{m}$ & $\mathrm{~m}$ & $\mathrm{~m}$ & $\mathrm{~m}$ & $\mathrm{~m}$ & $\mathrm{~m}$ \\
\hline $\mid \begin{array}{l}\text { Kussiann rederé } \\
\text { Saudi Arabia }\end{array}$ & $\begin{array}{l}\text { Bouls } \\
\text { Both levels }\end{array}$ & $\mathrm{m}$ & $\mathrm{m}$ & $\mathrm{m}$ & $\mathrm{m}$ & m & $\mathrm{m}$ & $\mathrm{m}$ & $\mathrm{m}$ & $\mathrm{m}$ & $\mathrm{m}$ & $\mathrm{m}$ & $\mathrm{m}$ \\
\hline Singapore ${ }^{\star \star}$ & $\begin{array}{l}\text { Both levels } \\
\text { Both Levels }\end{array}$ & Yes & No & No & Yes & $\mathrm{m}$ & $\mathrm{m}$ & $\mathrm{m}$ & $\mathrm{m}$ & No & No & Yes & No \\
\hline $\begin{array}{l}\text { Slovak Republic } \\
\text { Spain** }\end{array}$ & $\begin{array}{l}\text { Both levels } \\
\text { Both levels }\end{array}$ & $\begin{array}{l}\text { No } \\
\text { Yes }\end{array}$ & $\begin{array}{l}\text { No } \\
\text { Yes }\end{array}$ & $\begin{array}{l}\text { No } \\
\text { Yes }\end{array}$ & $\begin{array}{l}\text { No } \\
\text { Yes }\end{array}$ & $\underset{m}{m}$ & $\underset{m}{m}$ & $\underset{m}{m}$ & $\underset{m}{m}$ & $\begin{array}{l}\text { YYes } \\
\text { No }\end{array}$ & $\begin{array}{l}\text { Yes } \\
\text { No }\end{array}$ & $\begin{array}{l}\text { No } \\
\text { Yes }\end{array}$ & $\begin{array}{l}\text { Yes } \\
\text { Yes }\end{array}$ \\
\hline Switzerland & Pre-primary (ISCED 02) & Yes & No & No & Yes & $\mathrm{m}$ & $\mathrm{m}$ & $\mathrm{m}$ & $\mathrm{m}$ & No & No & Yes & Yes \\
\hline $\mid \begin{array}{l}\text { Turkey** } \\
\text { United Kingdom, }\end{array}$ & $\begin{array}{l}\text { Both levels } \\
\text { Both hevels }\end{array}$ & $\begin{array}{l}\text { Yes } \\
\text { Yes }\end{array}$ & No & $\begin{array}{l}\text { No } \\
\text { Yes }\end{array}$ & No & $\mathrm{m}$ & $\mathrm{m}$ & ${ }_{m}^{m}$ & $\mathrm{~m}$ & $\mathrm{~m}$ & $\mathrm{~m}$ & $\mathrm{~m}$ & $\mathrm{~m}$ \\
\hline
\end{tabular}

* G20 member countries are indicated with an asterisk.

* * 20 guest countries are indicated with a double asterisk.

Notes: Due to technical issues, responses for "children whose first language is different from the language used in the centre/school" were not recorded.

"m" - Missing information.

Source: OECD Survey on Distance Education for Young Children in 2020.

(C) OECD 2021 
Table A.4. [2/4] Reasons for difficulties to maintain continuity of education for groups of young children

Based on country reports

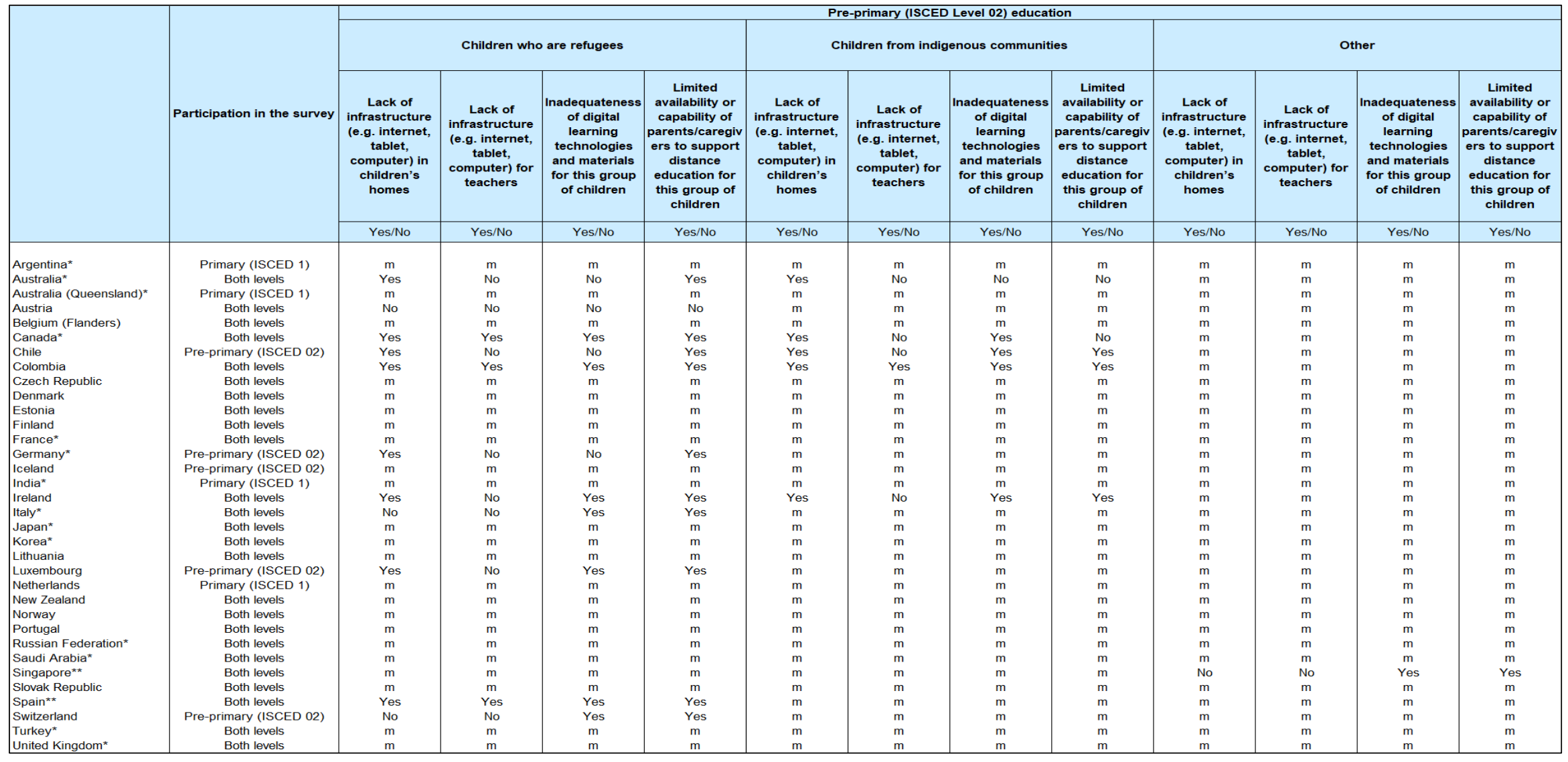

* $G 20$ member countries are indicated with an asterisk.

* * G20 guest countries are indicated with a double asterisk.

Notes: Due to technical issues, responses for "children whose first language is different from the language used in the centre/school" were not recorded.

"m" - Missing information.

Source: OECD Survey on Distance Education for Young Children in 2020. 
Table A.4. [3/4] Reasons for difficulties to maintain continuity of education for groups of young children

Based on country reports

\begin{tabular}{|c|c|c|c|c|c|c|c|c|c|c|c|c|c|}
\hline & \multirow{4}{*}{ Participation in the survey } & \multicolumn{12}{|c|}{ Primary (ISCED Level 1) education } \\
\hline & & \multicolumn{4}{|c|}{ Children from socio-economically disadvantaged homes } & \multicolumn{4}{|c|}{$\begin{array}{l}\text { Children whose first language is different from the language } \\
\text { used in the centre/school }\end{array}$} & \multicolumn{4}{|c|}{$\begin{array}{l}\text { Children with special educational needs (children who are } \\
\text { cognitively, physically or emotionally disadvantaged) }\end{array}$} \\
\hline & & $\begin{array}{l}\text { Lack of } \\
\text { infrastructure } \\
\text { (e.g. internet, } \\
\text { tablet, } \\
\text { computer) in } \\
\text { children's } \\
\text { homes }\end{array}$ & $\begin{array}{c}\text { Lack of } \\
\text { infrastructure } \\
\text { (e.g. internet, } \\
\text { tablet, } \\
\text { computer) for } \\
\text { teachers }\end{array}$ & $\begin{array}{c}\text { Inadequateness of } \\
\text { digital learning } \\
\text { technologies and } \\
\text { materials for this } \\
\text { group of children }\end{array}$ & \begin{tabular}{|c|} 
Limited \\
availability or \\
capability of \\
parents/caregi \\
verst to \\
support \\
distance \\
education for \\
this group of \\
children
\end{tabular} & $\begin{array}{l}\text { Lack of } \\
\text { infrastructure } \\
\text { (e.g. internet, } \\
\text { tablet, } \\
\text { computer) in } \\
\text { children's } \\
\text { homes }\end{array}$ & $\begin{array}{c}\text { Lack of } \\
\text { infrastructure } \\
\text { (e.g. internet, } \\
\text { tablet, } \\
\text { computer) for } \\
\text { teachers }\end{array}$ & $\begin{array}{c}\text { Inadequatenes } \\
\text { s of digital } \\
\text { learning } \\
\text { technologies } \\
\text { and materials } \\
\text { for this group } \\
\text { of children }\end{array}$ & \begin{tabular}{|c|} 
Limited \\
availability or \\
capability of \\
parents/caregi \\
vers to \\
support \\
distance \\
education for \\
this group of \\
children
\end{tabular} & $\begin{array}{c}\text { Lack of } \\
\text { infrastructure } \\
\text { (e.g. internet, } \\
\text { tablet, } \\
\text { computer) in } \\
\text { children's } \\
\text { homes }\end{array}$ & $\begin{array}{c}\text { Lack of } \\
\text { infrastructure } \\
\text { (e.g. internet, } \\
\text { tablet, } \\
\text { computer) for } \\
\text { teachers }\end{array}$ & $\begin{array}{c}\text { Inadequatenes } \\
\text { so of digital } \\
\text { learning } \\
\text { technologies } \\
\text { and materials } \\
\text { for this group } \\
\text { of children }\end{array}$ & \begin{tabular}{|c} 
Limited \\
availability or \\
capability of \\
parents/caregi \\
vers to \\
support \\
distance \\
education for \\
this group of \\
children
\end{tabular} \\
\hline & & Yes/No & Yes/No & Yes/No & Yes/No & Yes/No & Yes/No & Yes/No & Yes/No & Yes/No & Yes/No & Yes/No & Yes/No \\
\hline Argentina* & Primary (ISCED 1) & Yes & Yes & No & Yes & $\mathrm{m}$ & $\mathrm{m}$ & $\mathrm{m}$ & $\mathrm{m}$ & Yes & Yes & Yes & Yes \\
\hline Australia ${ }^{*}$ & $\begin{array}{l}\text { Both levels } \\
\text { B }\end{array}$ & $\mathrm{m}$ & $\mathrm{m}$ & $\mathrm{m}$ & $\mathrm{m}$ & $\mathrm{m}$ & $\mathrm{m}$ & $\mathrm{m}$ & $\mathrm{m}$ & $\mathrm{m}$ & $\mathrm{m}$ & $\mathrm{m}$ & $\mathrm{m}$ \\
\hline Australia (Queensland) & Primary (ISCED 1) & Yes & No & No & Yes & $\mathrm{m}$ & $\mathrm{m}$ & $\mathrm{m}$ & $\mathrm{m}$ & Yes & No & Yes & Yes \\
\hline Austria & Both levels & Yes & No & No & Yes & $\mathrm{m}$ & $\mathrm{m}$ & $\mathrm{m}$ & $\mathrm{m}$ & No & No & Yes & No \\
\hline Belgium (Flanders) & Both levels & Yes & No & No & Yes & $\mathrm{m}$ & $\mathrm{m}$ & $\mathrm{m}$ & $\mathrm{m}$ & No & No & Yes & No \\
\hline $\mid \begin{array}{l}\text { Canada* } \\
\text { Chile }\end{array}$ & $\begin{array}{l}\text { Both levels } \\
\text { Pre-primary (ISCED 02) }\end{array}$ & $\underset{\mathrm{m}}{\mathrm{m}}$ & $\underset{\mathrm{m}}{\mathrm{m}}$ & $\underset{\mathrm{m}}{\mathrm{m}}$ & $\underset{\mathrm{m}}{\mathrm{m}} \mathrm{r}-\mathrm{r}$ & $\underset{\mathrm{m}}{\mathrm{m}}$ & $\mathrm{m}$ & $\underset{\mathrm{m}}{\mathrm{m}}$ & $\mathrm{m}$ & $\mathrm{m}$ & $\mathrm{m}$ & $\mathrm{m}$ & $\mathrm{m}$ \\
\hline $\begin{array}{l}\text { Chile } \\
\text { Colombia }\end{array}$ & $\begin{array}{l}\text { Pre-primary (ISCED 02) } \\
\text { Both levels }\end{array}$ & $\begin{array}{l}\mathrm{m} \\
\text { Yes }\end{array}$ & $\begin{array}{l}\mathrm{m} \\
\text { No }\end{array}$ & $\begin{array}{l}\mathrm{m} \\
\text { Yes }\end{array}$ & $\begin{array}{l}\mathrm{m} \\
\text { Yes }\end{array}$ & 泾 & $\underset{m}{m}$ & $\underset{m}{m}$ & $\underset{m}{m}$ & $\begin{array}{l}\mathrm{m} \\
\text { No }\end{array}$ & $\begin{array}{l}\mathrm{m} \\
\text { No }\end{array}$ & $\begin{array}{l}\mathrm{m} \\
\text { Yes }\end{array}$ & $\begin{array}{l}m \\
\text { Yes }\end{array}$ \\
\hline Czech Republic & Both levels & Yes & No & No & Yes & $\mathrm{m}$ & $\mathrm{m}$ & $\mathrm{m}$ & $\mathrm{m}$ & Yes & No & Yes & Yes \\
\hline \begin{tabular}{|l} 
Denmark \\
Estonia
\end{tabular} & $\begin{array}{l}\text { Both levels } \\
\text { Both levels }\end{array}$ & Yes & No & No & Yes & $\mathrm{m}$ & $\mathrm{m}$ & $\mathrm{m}$ & $\mathrm{m}$ & No & No & Yes & Yes \\
\hline $\begin{array}{l}\text { Estonia } \\
\text { Finland }\end{array}$ & $\begin{array}{l}\text { Both levels } \\
\text { Roth }\end{array}$ & No & No & No & $\begin{array}{l}\text { Yes } \\
\text { Yyes }\end{array}$ & $\mathrm{m}$ & $\mathrm{m}$ & $\mathrm{m}$ & $\mathrm{m}$ & No & No & No & Yes \\
\hline $\mid \begin{array}{l}\text { Finland } \\
\text { France }{ }^{*}\end{array}$ & $\begin{array}{l}\text { Both hevels } \\
\text { Both levels }\end{array}$ & $\begin{array}{l}\text { Yes } \\
\text { Yes }\end{array}$ & $\begin{array}{l}\text { No } \\
\text { No }\end{array}$ & $\begin{array}{l}\text { No } \\
\text { No }\end{array}$ & $\begin{array}{l}\text { Yes } \\
\text { Yes }\end{array}$ & $\underset{m}{m}$ & $\underset{m}{m}$ & $\underset{\mathrm{m}}{\mathrm{m}}$ & $\underset{\mathrm{m}}{\mathrm{m}}$ & $\begin{array}{l}\text { No } \\
\text { No }\end{array}$ & $\begin{array}{l}\text { No } \\
\text { No }\end{array}$ & $\begin{array}{l}\text { Yes } \\
\text { Yes }\end{array}$ & $\begin{array}{r}\text { Yes } \\
\text { No }\end{array}$ \\
\hline Germany* & & $\mathrm{m}$ & $\mathrm{m}$ & $\mathrm{m}$ & $\begin{array}{c}\text { Yes } \\
\mathrm{m}\end{array}$ & 急 & 誉 & $\begin{array}{c}\mathrm{m} \\
\mathrm{m}\end{array}$ & $\begin{array}{l}\mathrm{m} \\
\mathrm{m}\end{array}$ & $\begin{array}{c}\text { No } \\
\mathrm{m}\end{array}$ & $\begin{array}{c}\text { No } \\
\mathrm{m}\end{array}$ & $\begin{array}{c}\text { Yes } \\
\text { m }\end{array}$ & $\begin{array}{c}\text { No } \\
m\end{array}$ \\
\hline Iceland & Pre-primary (ISCED 02) & $\mathrm{m}$ & $\mathrm{m}$ & $\mathrm{m}$ & $\mathrm{m}$ & $\mathrm{m}$ & $\mathrm{m}$ & $\mathrm{m}$ & $\mathrm{m}$ & $\mathrm{m}$ & $\mathrm{m}$ & $\mathrm{m}$ & m \\
\hline |India* & Primary (ISCED 1) & Yes & No & No & Yes & $\mathrm{m}$ & $\mathrm{m}$ & $\mathrm{m}$ & $\mathrm{m}$ & Yes & No & No & Yes \\
\hline Ireland & Both levels & Yes & No & No & Yes & $\mathrm{m}$ & $\mathrm{m}$ & $\mathrm{m}$ & $\mathrm{m}$ & No & No & Yes & No \\
\hline | Italy* & Both levels & Yes & No & No & Yes & $\mathrm{m}$ & $\mathrm{m}$ & $\mathrm{m}$ & $\mathrm{m}$ & Yes & No & Yes & Yes \\
\hline Japan* & Both levels & Yes & No & No & No & $\mathrm{m}$ & $\mathrm{m}$ & $\mathrm{m}$ & $\mathrm{m}$ & No & No & Yes & No \\
\hline Korea $^{*}$ & Both levels & Yes & No & No & Yes & $\mathrm{m}$ & $\mathrm{m}$ & $\mathrm{m}$ & $\mathrm{m}$ & No & No & Yes & Yes \\
\hline Lithuania & Both levels & Yes & No & Yes & Yes & $\mathrm{m}$ & $\mathrm{m}$ & $\mathrm{m}$ & $\mathrm{m}$ & Yes & No & Yes & Yes \\
\hline $\begin{array}{l}\text { Luxembourg } \\
\text { Netherlands }\end{array}$ & $\begin{array}{l}\text { Pre-primary (ISCED 02) } \\
\text { Primary (ISCED 1) }\end{array}$ & $\underset{\text { Yes }}{m}$ & $\begin{array}{l}m \\
\text { No }\end{array}$ & $\begin{array}{l}\mathrm{m} \\
\text { No }\end{array}$ & $\begin{array}{l}\mathrm{m} \\
\text { Yes }\end{array}$ & $\underset{m}{m}$ & $\begin{array}{l}\mathrm{m} \\
\mathrm{m}\end{array}$ & 蚝 & $\mathrm{m}$ & $\begin{array}{l}m \\
\text { No }\end{array}$ & $\begin{array}{l}\mathrm{m} \\
\mathrm{No}\end{array}$ & $\begin{array}{l}m \\
\text { Yes }\end{array}$ & $\begin{array}{l}m \\
\text { No }\end{array}$ \\
\hline $\begin{array}{l}\text { Netnentanss } \\
\text { New Zealand }\end{array}$ & $\begin{array}{l}\text { Both levels } \\
\text { Borl }\end{array}$ & $\begin{array}{l}\text { Pes } \\
\text { Yes }\end{array}$ & No & $\begin{array}{l}\text { No } \\
\text { No }\end{array}$ & $\begin{array}{l}\text { Pes } \\
\text { Yes }\end{array}$ & 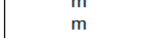 & $\begin{array}{c}\mathrm{m} \\
\mathrm{m}\end{array}$ & 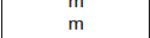 & $\begin{array}{c}\mathrm{m} \\
\mathrm{m}\end{array}$ & $\begin{array}{c}\text { No } \\
\mathrm{m}\end{array}$ & $\begin{array}{c}\text { No } \\
\mathrm{m}\end{array}$ & $\begin{array}{c}\text { Yes } \\
\mathrm{m}\end{array}$ & $\begin{array}{c}\text { No } \\
\mathrm{m}\end{array}$ \\
\hline Norway & Both levels & No & No & No & Yes & $\mathrm{m}$ & $\mathrm{m}$ & $\mathrm{m}$ & $\mathrm{m}$ & No & No & No & No \\
\hline Portugal & Both levels & Yes & No & No & No & $\mathrm{m}$ & $\mathrm{m}$ & $\mathrm{m}$ & $\mathrm{m}$ & $\mathrm{m}$ & $\mathrm{m}$ & $\mathrm{m}$ & $\mathrm{m}$ \\
\hline Russian Federation* & Both levels & $\mathrm{m}$ & $\mathrm{m}$ & $\mathrm{m}$ & $\mathrm{m}$ & $\mathrm{m}$ & $\mathrm{m}$ & $\mathrm{m}$ & $\mathrm{m}$ & $\mathrm{m}$ & $\mathrm{m}$ & $\mathrm{m}$ & $\mathrm{m}$ \\
\hline $\begin{array}{l}\text { Saudi Arabia } \\
\text { Singanor }\end{array}$ & $\begin{array}{l}\text { Both levels } \\
\text { Roth hevels }\end{array}$ & $\begin{array}{l}\mathrm{m} \\
\text { No }\end{array}$ & $\begin{array}{l}\mathrm{m} \\
\mathrm{No}\end{array}$ & $\begin{array}{l}\mathrm{m} \\
\text { No }\end{array}$ & $\mathrm{m}$ & $\mathrm{m}$ & $\mathrm{m}$ & $\mathrm{m}$ & $\mathrm{m}$ & $m$ & $\mathrm{~m}$ & $m$ & $\mathrm{~m}$ \\
\hline $\begin{array}{l}\text { Singapore } \text { S }^{\star *} \\
\text { Slovak Republic }\end{array}$ & $\begin{array}{l}\text { Both levels } \\
\text { Both levels }\end{array}$ & $\begin{array}{l}\text { No } \\
\text { Yes }\end{array}$ & $\begin{array}{l}\text { No } \\
\text { No }\end{array}$ & $\begin{array}{l}\text { No } \\
\text { Yes }\end{array}$ & $\begin{array}{l}\text { Yes } \\
\text { Yes }\end{array}$ & $\mathrm{m}$ & $\mathrm{m}$ & $\mathrm{m}$ & $\mathrm{m}$ & $\begin{array}{l}\text { No } \\
\text { Yes }\end{array}$ & $\begin{array}{l}\text { No } \\
\text { No }\end{array}$ & $\begin{array}{l}\text { No } \\
\text { Yes }\end{array}$ & $\begin{array}{l}\text { Yes } \\
\text { Yyes }\end{array}$ \\
\hline $\begin{array}{l}\text { Slovak Republic } \\
\text { Spain**}\end{array}$ & $\begin{array}{l}\text { Both levels } \\
\text { Both levels }\end{array}$ & $\begin{array}{l}\text { Yes } \\
\text { Yes }\end{array}$ & $\begin{array}{l}\text { Nos } \\
\text { Yes }\end{array}$ & $\begin{array}{l}\text { Yes } \\
\text { Yes }\end{array}$ & $\begin{array}{l}\text { Yes } \\
\text { Yes }\end{array}$ & m & m & $\begin{array}{l}\mathrm{m} \\
\mathrm{m}\end{array}$ & m & $\begin{array}{l}\text { Yes } \\
\text { No }\end{array}$ & No & $\begin{array}{l}\text { Yes } \\
\text { Yes }\end{array}$ & $\begin{array}{l}\text { Yes } \\
\text { Yes }\end{array}$ \\
\hline Switzerland & Pre-primary (ISCED 02) & $\mathrm{m}$ & $\mathrm{m}$ & $\mathrm{m}$ & $\mathrm{m}$ & $\mathrm{m}$ & $\mathrm{m}$ & $\mathrm{m}$ & $\mathrm{m}$ & $\mathrm{m}$ & $\mathrm{m}$ & $\mathrm{m}$ & $\begin{array}{l}\text { mes } \\
\mathrm{m}\end{array}$ \\
\hline $\begin{array}{l}\text { Turkey* } \\
\text { |urited Kingdom* }\end{array}$ & Both levels & Yes & No & No & No & $\mathrm{m}$ & $\mathrm{m}$ & $\mathrm{m}$ & $\mathrm{m}$ & $m$ & $m$ & $m$ & $m$ \\
\hline & Both levels & & No & & & & & & & & & Yes & \\
\hline
\end{tabular}

* G20 member countries are indicated with an asterisk.

* * G20 guest countries are indicated with a double asterisk.

Notes: Due to technical issues, responses for "children whose first language is different from the language used in the centre/school" were not recorded.

"m" - Missing information.

Source: OECD Survey on Distance Education for Young Children in 2020.

(c) OECD 2021 
Table A.4. [4/4] Reasons for difficulties to maintain continuity of education for groups of young children

Based on country reports

\begin{tabular}{|c|c|c|c|c|c|c|c|c|c|c|c|c|c|}
\hline & \multirow{4}{*}{ Participation in the survey } & \multicolumn{12}{|c|}{ Primary (ISCED Level 1) education } \\
\hline & & \multicolumn{4}{|c|}{ Children who are refugees } & \multicolumn{4}{|c|}{ Children from indigenous communities } & \multicolumn{4}{|c|}{ Other } \\
\hline & & $\begin{array}{l}\text { Lack of } \\
\text { infrastructure } \\
\text { (e.g. internet, } \\
\text { tablet, } \\
\text { computer) in } \\
\text { children's } \\
\text { homes }\end{array}$ & $\begin{array}{c}\text { Lack of } \\
\text { infrastructure } \\
\text { (e.g. internet, } \\
\text { tablet, } \\
\text { computer) for } \\
\text { teachers }\end{array}$ & $\begin{array}{l}\text { Inadequateness } \\
\text { of digital learning } \\
\text { technologies and } \\
\text { materials for this } \\
\text { group of children }\end{array}$ & \begin{tabular}{|c|} 
Limited \\
availability or \\
capability of \\
parents/caregiv \\
ers to support \\
distance \\
education for \\
this group of \\
children
\end{tabular} & $\begin{array}{c}\text { Lack of } \\
\text { infrastructure } \\
\text { (e.g. internet, } \\
\text { tablet, } \\
\text { computer) in } \\
\text { children's } \\
\text { homes }\end{array}$ & $\begin{array}{c}\text { Lack of } \\
\text { infrastructure } \\
\text { (e.g. internet, } \\
\text { tablet, } \\
\text { computer) for } \\
\text { teachers }\end{array}$ & $\begin{array}{c}\text { Inadequateness } \\
\text { of digitial } \\
\text { learning } \\
\text { technologies } \\
\text { and materials } \\
\text { for this group } \\
\text { of children }\end{array}$ & \begin{tabular}{|c|} 
Limited \\
availability or \\
capability of \\
parents/caregiv \\
ers to support \\
distance \\
education for \\
this group of \\
children
\end{tabular} & $\begin{array}{l}\text { Lack of } \\
\text { infrastructure } \\
\text { (e.g. internet, } \\
\text { tablet, } \\
\text { computer) in } \\
\text { children's } \\
\text { homes }\end{array}$ & $\begin{array}{c}\text { Lack of } \\
\text { infrastructure } \\
\text { (e.g. internet, } \\
\text { tablet, } \\
\text { computer) for } \\
\text { teachers }\end{array}$ & $\begin{array}{c}\text { Inadequateness } \\
\text { of digitial } \\
\text { learning } \\
\text { technologies } \\
\text { and materials } \\
\text { for this group } \\
\text { of children }\end{array}$ & \begin{tabular}{|c} 
Limited \\
availability or \\
capability of \\
parents/caregiv \\
ers to support \\
distance \\
education for \\
this group of \\
children
\end{tabular} \\
\hline & & Yes/No & Yes/No & Yes/No & Yes/No & Yes/No & Yes/No & Yes/No & Yes/No & Yes/No & Yes/No & Yes/No & Yes/No \\
\hline Argentina* & Primary (ISCED 1) & $\mathrm{m}$ & $\mathrm{m}$ & $\mathrm{m}$ & $\mathrm{m}$ & Yes & Yes & No & Yes & $\mathrm{m}$ & $\mathrm{m}$ & $\mathrm{m}$ & $\mathrm{m}$ \\
\hline \begin{tabular}{|l} 
Australia $^{*}$ \\
AAstralia (Queensland)*
\end{tabular} & $\begin{array}{l}\text { Both levels } \\
\text { Primary (ISCED 1) }\end{array}$ & $\mathrm{y}_{\text {Yes }}$ & $\mathrm{m}$ & $\mathrm{m}$ & $\mathrm{m}$ & $\mathrm{m}$ & $\mathrm{m}$ & $\mathrm{m}$ & Yes & $\mathrm{m}$ & $\mathrm{m}$ & & $\mathrm{m}$ \\
\hline $\mid \begin{array}{l}\text { Australia (Queensland)* } \\
\text { Austria }\end{array}$ & $\begin{array}{l}\text { Primary (ISCED 1) } \\
\text { Both hevels }\end{array}$ & $\begin{array}{l}\text { Yes } \\
\text { Yes }\end{array}$ & $\begin{array}{l}\text { No } \\
\text { No }\end{array}$ & $\begin{array}{l}\text { No } \\
\text { Yes }\end{array}$ & $\begin{array}{l}\text { Yes } \\
\text { Yes }\end{array}$ & $\begin{array}{c}\text { Yes } \\
\mathrm{m}\end{array}$ & No & No & Yes & $\mathrm{m}$ & $\mathrm{m}$ & $\mathrm{m}$ & $\underset{\mathrm{m}}{\mathrm{m}}$ \\
\hline $\begin{array}{l}\text { Austida (Flanders) } \\
\text { Belgium (Fla }\end{array}$ & Both levels & $\mathrm{m}$ & $\mathrm{m}$ & m & $\begin{array}{l}\text { res } \\
\mathrm{m}\end{array}$ & $\frac{m}{m}$ & $\mathrm{~m}$ & $\mathrm{~m}$ & $\mathrm{~m}$ & $\underset{m}{m}$ & $\underset{\mathrm{m}}{\mathrm{m}}$ & $\underset{m}{m}$ & m \\
\hline Canada $^{*}$ & Both levels & $\mathrm{m}$ & $\mathrm{m}$ & $\mathrm{m}$ & $\mathrm{m}$ & $\mathrm{m}$ & $\mathrm{m}$ & $\mathrm{m}$ & $\mathrm{m}$ & $\mathrm{m}$ & $\mathrm{m}$ & $\mathrm{m}$ & $\mathrm{m}$ \\
\hline Chile & Pre-primary (ISCED 02) & $\mathrm{m}$ & $\mathrm{m}$ & $\mathrm{m}$ & $\mathrm{m}$ & $\mathrm{m}$ & $\mathrm{m}$ & $\mathrm{m}$ & $\mathrm{m}$ & $\mathrm{m}$ & $\mathrm{m}$ & $\mathrm{m}$ & $\mathrm{m}$ \\
\hline $\begin{array}{l}\text { Colombia } \\
\text { Czech Republic }\end{array}$ & Both levels & $\mathrm{m}$ & $\mathrm{m}$ & $\mathrm{m}$ & $\mathrm{m}$ & Yes & No & Yes & Yes & $\mathrm{m}$ & $\mathrm{m}$ & $\mathrm{m}$ & $\mathrm{m}$ \\
\hline $\mid \begin{array}{l}\text { Zzech Republic } \\
\text { Denmark }\end{array}$ & $\begin{array}{l}\text { Both levels } \\
\text { Both levels }\end{array}$ & $\underset{\mathrm{m}}{\mathrm{m}}$ & $\underset{\mathrm{m}}{\mathrm{m}}$ & $\underset{\mathrm{m}}{\mathrm{m}}$ & $\underset{\mathrm{m}}{\mathrm{m}}$ & $\underset{\mathrm{m}}{\mathrm{m}}$ & $\underset{m}{m}$ & $\underset{\mathrm{m}}{\mathrm{m}}$ & $\underset{\mathrm{m}}{\mathrm{m}}$ & $\underset{m}{m}$ & $\mathrm{~m}$ & $\mathrm{~m}$ & $\mathrm{~m}$ \\
\hline $\begin{array}{l}\begin{array}{l}\text { Denmark } \\
\text { Estonia }\end{array} \\
\end{array}$ & $\begin{array}{l}\text { Both hevels } \\
\text { Both levels }\end{array}$ & $\begin{array}{l}\mathrm{m} \\
\text { No }\end{array}$ & $\begin{array}{l}\mathrm{m} \\
\text { No }\end{array}$ & $\begin{array}{l}\mathrm{m} \\
\text { No }\end{array}$ & $\underset{\text { Yes }}{m}$ & $\underset{\mathrm{m}}{\mathrm{m}}$ & $\underset{m}{m}$ & $\underset{\mathrm{m}}{\mathrm{m}}$ & $\underset{m}{m}$ & $\begin{array}{c}\mathrm{m} \\
\mathrm{m}\end{array}$ & $\begin{array}{c}m \\
m\end{array}$ & $\underset{m}{m}$ & $\begin{array}{l}\mathrm{m} \\
\mathrm{m}\end{array}$ \\
\hline Finland & Both levels & $\mathrm{m}$ & $\mathrm{m}$ & $\mathrm{m}$ & $\mathrm{m}$ & $\mathrm{m}$ & $\mathrm{m}$ & $\mathrm{m}$ & $\begin{array}{c}m \\
m\end{array}$ & $\begin{array}{c}\mathrm{m} \\
\mathrm{m}\end{array}$ & $\begin{array}{c}\mathrm{m} \\
\mathrm{m}\end{array}$ & $\begin{array}{c}m \\
m\end{array}$ & $\begin{array}{c}\mathrm{m} \\
\mathrm{m}\end{array}$ \\
\hline France ${ }^{*}$ & 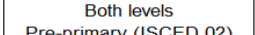 & $\mathrm{m}$ & $\mathrm{m}$ & $\mathrm{m}$ & $\mathrm{m}$ & $\mathrm{m}$ & $\mathrm{m}$ & $\mathrm{m}$ & $\mathrm{m}$ & $\mathrm{m}$ & $\mathrm{m}$ & $\mathrm{m}$ & $\mathrm{m}$ \\
\hline $\begin{array}{l}\text { Germany* } \\
\text { lceland }\end{array}$ & $\begin{array}{l}\text { Pre-primary (ISCED 02) } \\
\text { Pre-primary (ISCED 02) }\end{array}$ & $\underset{\mathrm{m}}{\mathrm{m}}$ & $\underset{\mathrm{m}}{\mathrm{m}}$ & $\underset{\mathrm{m}}{\mathrm{m}}$ & $\underset{\mathrm{m}}{\mathrm{m}}$ & $\underset{\mathrm{m}}{\mathrm{m}}$ & $\underset{m}{m}$ & $\underset{\mathrm{m}}{\mathrm{m}}$ & $\underset{\mathrm{m}}{\mathrm{m}}$ & $\underset{\mathrm{m}}{\mathrm{m}}$ & $\mathrm{m}$ & $\mathrm{m}$ & $\mathrm{m}$ \\
\hline 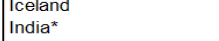 & $\begin{array}{l}\text { Pre-primary (ISCED 0) } \\
\text { Primary (ISCED 1) }\end{array}$ & $\begin{array}{l}\mathrm{m} \\
\text { Yes }\end{array}$ & $\begin{array}{l}\mathrm{m} \\
\text { No }\end{array}$ & $\begin{array}{l}m \\
\text { No }\end{array}$ & $\begin{array}{c}\mathrm{m} \\
\text { Yes }\end{array}$ & $\begin{array}{l}\mathrm{m} \\
\text { Yes }\end{array}$ & $\begin{array}{l}\mathrm{m} \\
\text { No }\end{array}$ & $\begin{array}{l}\mathrm{m} \\
\text { No }\end{array}$ & $\begin{array}{l}\mathrm{m} \\
\text { Yes }\end{array}$ & $\begin{array}{c}\mathrm{m} \\
\mathrm{m}\end{array}$ & $\begin{array}{c}m \\
m\end{array}$ & $\underset{m}{m}$ & $\begin{array}{l}\mathrm{m} \\
\mathrm{m}\end{array}$ \\
\hline Ireland & Both levels & Yes & No & No & Yes & Yes & No & No & Yes & $\mathrm{m}$ & $\mathrm{m}$ & $\mathrm{m}$ & m \\
\hline Italy* & Both levels & No & No & Yes & Yes & $\mathrm{m}$ & $\mathrm{m}$ & $\mathrm{m}$ & $\mathrm{m}$ & No & No & No & No \\
\hline $\mid \begin{array}{l}\text { Japan** } \\
\text { Korea*a* }^{*}\end{array}$ & $\begin{array}{l}\text { Both levels } \\
\text { Both hevels }\end{array}$ & $\mathrm{m}$ & $\mathrm{m}$ & $\underset{m}{m}$ & $\mathrm{~m}$ & $\mathrm{~m}$ & $\mathrm{~m}$ & $\mathrm{~m}$ & $\underset{\mathrm{m}}{\mathrm{m}}$ & $\underset{\mathrm{m}}{\mathrm{m}}$ & $\mathrm{m}$ & $\mathrm{m}$ & $\mathrm{m}$ \\
\hline 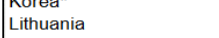 & $\begin{array}{l}\text { Both levels } \\
\text { Both levels }\end{array}$ & $\underset{m}{m}$ & $\begin{array}{c}m \\
m\end{array}$ & $\begin{array}{c}m \\
m\end{array}$ & $\begin{array}{c}m \\
m\end{array}$ & $\begin{array}{l}\mathrm{m} \\
\text { Yes }\end{array}$ & $\begin{array}{l}m \\
\text { No }\end{array}$ & $\begin{array}{l}\mathrm{m} \\
\text { No }\end{array}$ & $\begin{array}{l}\mathrm{m} \\
\text { Yes }\end{array}$ & $\underset{m}{m}$ & $\underset{m}{m}$ & $\underset{m}{m}$ & $\begin{array}{l}\mathrm{m} \\
\mathrm{m}\end{array}$ \\
\hline Luxembourg & Pre-primary (ISCED 02) & $m$ & $\mathrm{~m}$ & $\mathrm{~m}$ & $\mathrm{~m}$ & $\mathrm{~m}$ & $\mathrm{~m}$ & & $\mathrm{~m}$ & $\mathrm{~m}$ & $\mathrm{~m}$ & m & m \\
\hline Netherlands & $\begin{array}{l}\text { Primary (ISCED 1) } \\
\text { Pots }\end{array}$ & Yes & No & Yes & Yes & Yes & No & No & & $\mathrm{m}$ & $\mathrm{m}$ & & $\mathrm{m}$ \\
\hline New Zealand & Both levels & $\mathrm{m}$ & $\mathrm{m}$ & $\begin{array}{l}m \\
\text { Yes }\end{array}$ & $\mathrm{y}_{\mathrm{yes}}$ & $\mathrm{m}$ & $\mathrm{m}$ & $\mathrm{m}$ & $\mathrm{m}$ & $\mathrm{m}$ & $\mathrm{m}$ & $\mathrm{m}$ & $\mathrm{m}$ \\
\hline $\mid \begin{array}{l}\text { Norway } \\
\text { Portugal }\end{array}$ & $\begin{array}{l}\text { Both levels } \\
\text { Both elevels }\end{array}$ & $\begin{array}{l}\text { No } \\
\mathrm{m}\end{array}$ & No ${ }_{\mathrm{m}}^{\mathrm{N}}$ & $\begin{array}{l}\text { Yes } \\
\mathrm{m}\end{array}$ & $\begin{array}{c}\text { Yes } \\
\mathrm{m}\end{array}$ & $\mathrm{m}$ & $\mathrm{m}$ & $\mathrm{m}$ & $\mathrm{m}$ & $\mathrm{m}$ & $\mathrm{m}$ & $\mathrm{m}$ & $\mathrm{m}$ \\
\hline Russian Federation* & $\begin{array}{l}\text { Both levels } \\
\text { Both levels }\end{array}$ & $\underset{m}{m}$ & $\frac{\mathrm{m}}{\mathrm{m}}$ & $\begin{array}{c}\mathrm{m} \\
\mathrm{m}\end{array}$ & $\frac{\mathrm{m}}{\mathrm{m}}$ & $\underset{m}{m}$ & $\mathrm{~m}$ & $\mathrm{~m}$ & $\mathrm{~m}$ & $\mathrm{~m}$ & $\mathrm{~m}$ & $\mathrm{~m}$ & $\mathrm{~m}$ \\
\hline Saudi Arabia* & $\begin{array}{l}\text { Both levels } \\
\text { Both levels }\end{array}$ & $m$ & $\mathrm{~m}$ & $\mathrm{~m}$ & $\mathrm{~m}$ & $\mathrm{~m}$ & $\underset{m}{m}$ & $\mathrm{~m}$ & $\mathrm{~m}$ & $\mathrm{~m}$ & $\mathrm{~m}$ & $\mathrm{~m}$ & $\mathrm{~m}$ \\
\hline Singapore $e^{\star \star}$ & $\begin{array}{l}\text { Both levels } \\
\text { Both levels }\end{array}$ & $\mathrm{m}$ & $\mathrm{m}$ & $\mathrm{m}$ & $\mathrm{m}$ & $\mathrm{m}$ & $\mathrm{m}$ & $\mathrm{m}$ & $\frac{m}{m}$ & $\begin{array}{c}\mathrm{m} \\
\mathrm{m}\end{array}$ & $\begin{array}{c}m \\
m\end{array}$ & $\begin{array}{c}\mathrm{m} \\
\mathrm{m}\end{array}$ & $\begin{array}{l}\mathrm{m} \\
\mathrm{m}\end{array}$ \\
\hline Slovak Republic & Both levels & No & No & Yes & Yes & $\mathrm{m}$ & $\mathrm{m}$ & $\mathrm{m}$ & $\mathrm{m}$ & $\mathrm{m}$ & $\mathrm{m}$ & $\mathrm{m}$ & $\mathrm{m}$ \\
\hline Spain ${ }^{* *}$ & Both levels & Yes & Yes & Yes & Yes & $\mathrm{m}$ & $\mathrm{m}$ & $\mathrm{m}$ & $\mathrm{m}$ & $\mathrm{m}$ & $\mathrm{m}$ & $\mathrm{m}$ & $\mathrm{m}$ \\
\hline Switzerland & Pre-primary (ISCED 02) & $\mathrm{m}$ & $\mathrm{m}$ & $\mathrm{m}$ & $\mathrm{m}$ & $\mathrm{m}$ & $\mathrm{m}$ & $\mathrm{m}$ & $\mathrm{m}$ & $\mathrm{m}$ & $\mathrm{m}$ & $\mathrm{m}$ & $\mathrm{m}$ \\
\hline $\begin{array}{l}\text { Turkey" } \\
\text { United Kingdom* }\end{array}$ & $\begin{array}{l}\text { Both levels } \\
\text { Both levels }\end{array}$ & $\begin{array}{c}m \\
m\end{array}$ & $\begin{array}{c}m \\
m\end{array}$ & $\begin{array}{c}m \\
m\end{array}$ & $\begin{array}{c}m \\
m\end{array}$ & $\begin{array}{c}m \\
m\end{array}$ & $\begin{array}{c}m \\
m\end{array}$ & $\begin{array}{c}m \\
m\end{array}$ & $\begin{array}{l}m \\
m\end{array}$ & $\begin{array}{l}\mathrm{m} \\
\text { No }\end{array}$ & $\begin{array}{l}m \\
\text { No } \\
\text { No }\end{array}$ & $\begin{array}{l}\mathrm{m} \\
\text { No }\end{array}$ & $\begin{array}{l}\text { m } \\
\text { No }\end{array}$ \\
\hline
\end{tabular}

* G20 member countries are indicated with an asterisk.

** G20 guest countries are indicated with a double asterisk.

Notes: Due to technical issues, responses for "children whose first language is different from the language used in the centre/school" were not recorded.

"m" - Missing information.

Source: OECD Survey on Distance Education for Young Children in 2020. 
Table A.5. Change in approach to integrating digital technologies in early education

Based on country reports

\begin{tabular}{|c|c|c|c|}
\hline & \multirow{3}{*}{$\begin{array}{l}\text { Participation in the } \\
\text { survey }\end{array}$} & Pre-primary (ISCED Level 02) education & Primary (ISCED Level 1) education \\
\hline & & $\begin{array}{l}\text { Change in agency's/organisation's approach to } \\
\text { integrating digital technologies in early } \\
\text { childhood education and care settings due to } \\
\text { the COVID-19 pandemic }\end{array}$ & $\begin{array}{c}\text { Change in agency's/organisation's } \\
\text { approach to integrating digital } \\
\text { technologies in early childhood education } \\
\text { and care settings due to the COVID-19 } \\
\text { pandemic }\end{array}$ \\
\hline & & Level of extent & Level of extent \\
\hline 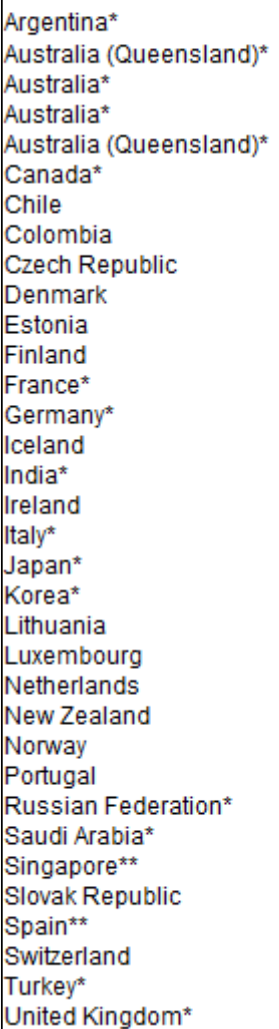 & $\begin{array}{c}\text { Both levels } \\
\text { Primary (ISCED 1) } \\
\text { Both levels } \\
\text { Both levels } \\
\text { Both levels } \\
\text { Both levels } \\
\text { Both levels } \\
\text { Both levels } \\
\text { Both levels } \\
\text { Both levels } \\
\text { Both levels } \\
\text { Both levels } \\
\text { Pre-primary (ISCED 02) } \\
\text { Pre-primary (ISCED 02) } \\
\text { Both levels } \\
\text { Both levels } \\
\text { Both levels } \\
\text { Both levels } \\
\text { Both levels } \\
\text { Pre-primary (ISCED 02) } \\
\text { Primary (ISCED 1) } \\
\text { Both levels } \\
\text { Both levels } \\
\text { Both levels } \\
\text { Both levels } \\
\text { Both levels } \\
\text { Pre-primary (ISCED 02) } \\
\text { Both levels } \\
\text { Both levels } \\
\text { Primary (ISCED 1) } \\
\text { Primary (ISCED 1) } \\
\text { Both levels } \\
\text { Both levels } \\
\text { Both levels }\end{array}$ & $\begin{array}{c}\text { m } \\
\text { Yes, to some extent } \\
\text { m } \\
\text { Yes, to some extent } \\
\text { Yes, substantially } \\
\text { Yes, substantially } \\
\text { Yes, substantially } \\
\text { Yes, substantially } \\
\text { Yes, to some extent } \\
\text { No } \\
\text { Yes, substantially } \\
\text { Yes, to some extent } \\
\text { Yes, to some extent } \\
\text { Yes, to some extent } \\
\text { No } \\
\text { m } \\
\text { Yes, substantially } \\
\text { Yes, substantially } \\
\text { Yes, substantially } \\
\text { Yes, to some extent } \\
\text { Yes, to some extent } \\
\text { Yes, to some extent } \\
\text { m } \\
\text { No } \\
\text { No } \\
\text { Yes, substantially } \\
\text { No } \\
\text { Yes, to some extent } \\
\text { Yes, to some extent } \\
\text { Yes, to some extent } \\
\text { Not applicable } \\
\text { Yes, substantially } \\
\text { Yes, to some extent } \\
\text { No }\end{array}$ & $\begin{array}{c}\text { Yes, substantially } \\
\text { Not applicable } \\
\text { Yes, substantially } \\
\text { Yes, to some extent } \\
\text { Yes, substantially } \\
\text { Not known } \\
\text { m } \\
\text { Yes, substantially } \\
\text { Yes, substantially } \\
\text { Yes, to some extent } \\
\text { Yes, to some extent } \\
\text { Yes, to some extent } \\
\text { Yes, substantially } \\
\text { m } \\
\text { m } \\
\text { Yes, substantially } \\
\text { No } \\
\text { Yes, substantially } \\
\text { Yes, substantially } \\
\text { Yes, substantially } \\
\text { Yes, to some extent } \\
\text { m } \\
\text { Yes, to some extent } \\
\text { No } \\
\text { Yes, to some extent } \\
\text { Yes, substantially } \\
\text { Yes, to some extent } \\
\text { Yes, to some extent } \\
\text { No } \\
\text { Yes, to some extent } \\
\text { Not applicable } \\
\text { m } \\
\text { Yes, to some extent } \\
\text { Yes, to some extent }\end{array}$ \\
\hline
\end{tabular}

* G20 member countries are indicated with an asterisk.

** G20 guest countries are indicated with a double asterisk.

Note: "m" - Missing information.

Source: OECD Survey on Distance Education for Young Children in 2020. 
This work is published under the responsibility of the Secretary-General of the OECD. The opinions expressed and arguments employed herein do not necessarily reflect the official views of OECD member countries.

This document, as well as any data and any map included herein, are without prejudice to the status of or sovereignty over any territory, to the delimitation of international frontiers and boundaries and to the name of any territory, city or area.

Photo credits: Cover

(c) Shutterstock/fizkes; @ Shutterstock/New Africa; @ Shutterstock/Robert Kneschke.

The use of this work, whether digital or print, is governed by the Terms and Conditions to be found at http://www.oecd.org/termsandconditions.

The OECD is compiling data, information, analysis and recommendations regarding the health, economic, financial and societal challenges posed by the impact of coronavirus (COVID-19). Please visit our dedicated page for a full suite of coronavirus-related information. 
Find out more at

https://www.oecd.org/education/school/earlychildhoodeducationandcare.htm

For more information, contact

edu.contact@oecd.org

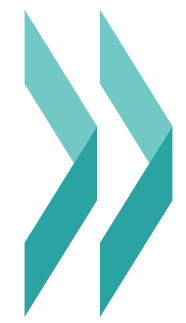

Connect with us:

- edu.contact@oecd.org

- @OECDEduSkills

1 https://oecdedutoday.com/

f OECD Education and skills

a https://www.oecd-ilibrary.org/education

(0)@oecd_education_skills

Visit www.oecd.org

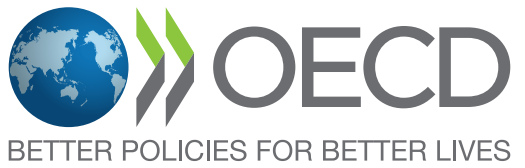

